LBNL-53924

\title{
Modeling Energy Consumption of Residential Furnaces and Boilers in U.S. Homes
}

\author{
James Lutz, Camilla Dunham-Whitehead, Alex Lekov, and James McMahon \\ Energy Analysis Department \\ Environmental Energy Technologies Division \\ Ernest Orlando Lawrence Berkeley National Laboratory \\ University of California \\ Berkeley, CA 94720
}

February 2004

This work was supported by the Office of Building Technologies and Community Systems of the U.S. Department of Energy, under Contract No. DE-AC03-76SF00098. 



\begin{abstract}
In 2001, DOE initiated a rulemaking process to consider whether to amend the existing energy efficiency standards for furnaces and boilers. A key factor in DOE's consideration of new standards is their cost-effectiveness to consumers. Determining cost-effectiveness requires an appropriate comparison of the additional first cost of energy efficiency design options with the savings in operating costs. This report describes calculation of equipment energy consumption (fuel and electricity) based on estimated conditions in a sample of homes that are representative of expected furnace and boiler installations. To represent actual houses with furnaces and boilers in the United States, we used a set of houses from the Residential Energy Consumption Survey of 1997 conducted by the Energy Information Administration. Our calculation methodology estimates the energy consumption of alternative (more-efficient) furnaces, if they were to be used in each house in place of the existing equipment. We developed the method of calculation described in this report for non-weatherized gas furnaces. We generalized the energy consumption calculation for this product class to the other furnace product classes. Fuel consumption calculations for boilers are similar to those for the other furnace product classes. The electricity calculations for boilers are simpler than for furnaces, because boilers do not provide thermal distribution for space cooling as furnaces often do.
\end{abstract}





\section{TABLE OF CONTENTS}

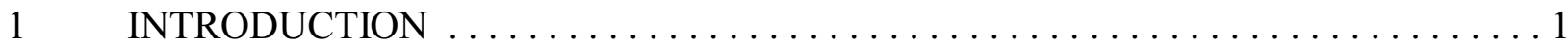

2 FURNACE AND BOILER TECHNOLOGY OVERVIEW $\ldots \ldots \ldots \ldots \ldots \ldots \ldots . \ldots . \ldots . \ldots$

3 METHOD FOR NON-WEATHERIZED GAS FURNACES $\ldots \ldots \ldots \ldots \ldots \ldots \ldots \ldots$

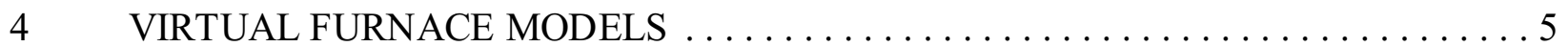

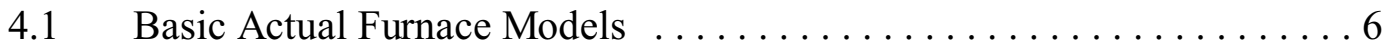

4.2 Input Capacity and Maximum Airflow $\ldots \ldots \ldots \ldots \ldots \ldots \ldots \ldots$

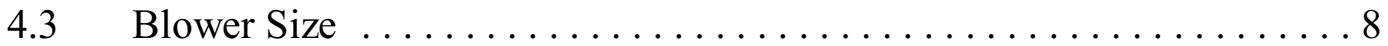

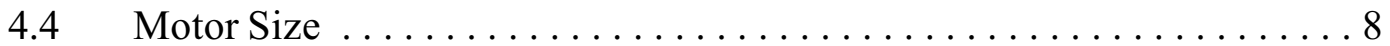

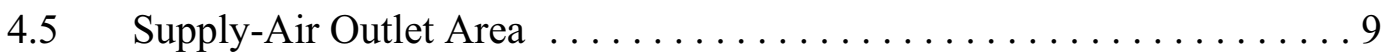

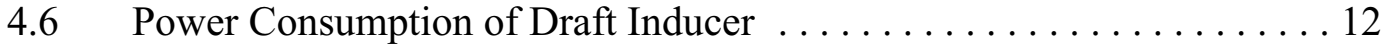

4.7 Delay Times ................................. 13

5 ASSIGNING EXISTING EQUIPMENT TO SAMPLE HOUSES $\ldots \ldots \ldots \ldots \ldots \ldots 13$

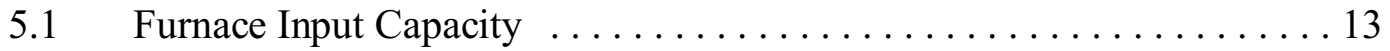

$5.2 \quad$ Airflow Capacity ............................... 14

5.3 Efficiency Characteristics of Existing Equipment $\ldots \ldots \ldots \ldots \ldots \ldots$

5.4 Electricity Consumption of Existing Furnace Blower .......... 16

6 CALCULATING FURNACE BLOWER ELECTRICITY CONSUMPTION . . . . . 16

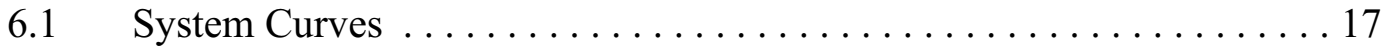

$6.2 \quad$ Furnace Fan Curves ........................... 18

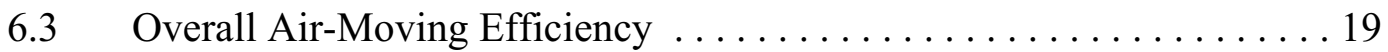

6.4 Blower Motor Electricity Consumption $\ldots \ldots \ldots \ldots \ldots \ldots \ldots . \ldots 23$

7 ANNUAL HEATING AND COOLING LOADS IN SAMPLE HOUSES . . . . . . . . . 23

7.1 Annual House Heating Load ............................ 23

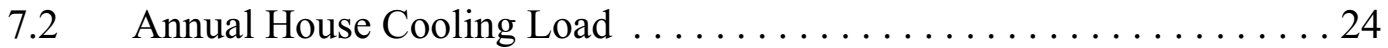

8 FURNACE ENERGY CONSUMPTION ......................... 24

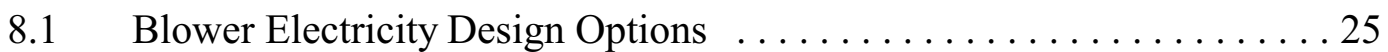

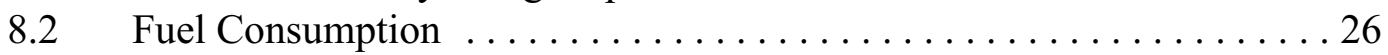

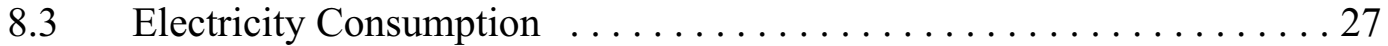

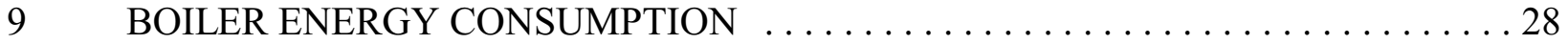

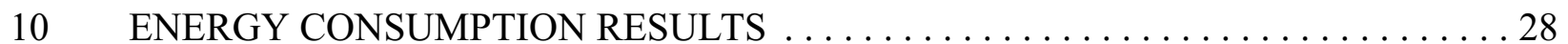

\section{LIST OF TABLES}

Table 1.1 Market Statistics for Furnaces and Boilers by Product Class $\ldots \ldots \ldots \ldots \ldots 2$

Table $2.1 \quad$ Furnace and Boiler Efficiency ........................... 4

Table $4.1 \quad$ Characteristics of Basic Furnace Models . . . . . . . . . . . . . . . . . 6

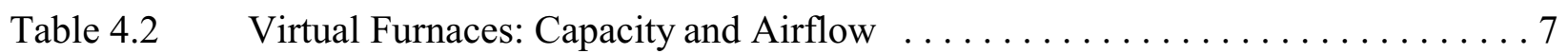

Table $4.3 \quad$ Assigned Blower Size by Airflow Capacity $\ldots \ldots \ldots \ldots \ldots \ldots \ldots \ldots$ 
Table 4.4

Table 4.5

Table 4.6

Table 4.7

Table 10.1

Table 10.2

Table 10.3

Table 10.4

Table 10.5

Table 10.6

Assigned Motor Size by Airflow Capacity $\ldots \ldots \ldots \ldots \ldots \ldots \ldots$

Supply-Air Outlet Area for Virtual Non-Condensing Gas Furnace Models . . . . 12 Supply-Air Outlet Area for Virtual Condensing Gas Furnace Models . . . . . . 12 Values for Delay and Ignition Times $\ldots \ldots \ldots \ldots \ldots \ldots \ldots \ldots \ldots \ldots$ Annual Energy Consumption of Non-Weatherized Gas Furnaces by Design

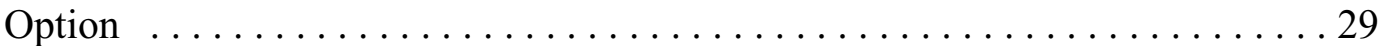
Annual Energy Consumption of Weatherized Furnaces by Design Option . . . . 31 Annual Energy Consumption of Manufactured-Home Furnaces by Design Option

Annual Energy Consumption of Oil Furnaces by Design Option ......... 33

Annual Energy Consumption of Gas Boilers by Design Option .......... 34

Annual Energy Consumption of Oil Boilers by Design Option ........... 35

\section{LIST OF FIGURES}

Figure $4.1 \quad$ Number of Furnace Models by Input Capacity $\ldots \ldots \ldots \ldots \ldots \ldots \ldots \ldots$

Figure 4.2 Supply-Air Outlet Area for Non-Condensing Natural Gas Furnaces $\ldots \ldots \ldots 10$

Figure 4.3 Supply-Air Outlet Area for Condensing Natural Gas Furnaces . . . . . . . . . 11

Figure $5.1 \quad$ Percent of Existing Furnaces by Input Capacity $\ldots \ldots \ldots \ldots \ldots \ldots \ldots \ldots \ldots$

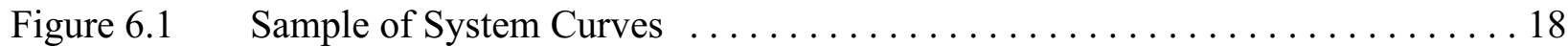

Figure 6.2 Fan Curves for $800 \mathrm{cfm}$ Virtual Furnace Model .................. 19

Figure $6.3 \quad$ Fan Curves for $1200 \mathrm{cfm}$ Virtual Furnace Model ................... 19

Figure $6.4 \quad$ Fan Curves for $1600 \mathrm{cfm}$ Virtual Furnace Model . . . . . . . . . . . . . . . . . . 19

Figure $6.5 \quad$ Fan Curves for $2000 \mathrm{cfm}$ Virtual Furnace Model ................... 19

Figure 6.6 Overall Air-Moving Efficiency of Existing Furnaces $\ldots \ldots \ldots \ldots \ldots \ldots \ldots \ldots$

Figure 6.7 Overall Air-Moving Efficiency of Non-Condensing Virtual Furnace Models

Figure 6.8 Overall Air-Moving Efficiency of Condensing Virtual Furnace Models . . . . 22

\section{APPENDICES}

APPENDIX A: DATABASE OF REDUCED SET OF FURNACE MODELS $\ldots \ldots \ldots$ A-1 APPENDIX B: MANUFACTURER MODEL NUMBERS $\ldots \ldots \ldots \ldots \ldots \ldots \ldots \ldots . . \ldots . . \ldots \ldots$ APPENDIX C: BASIC FURNACE MODEL DETERMINATION $\ldots \ldots \ldots \ldots \ldots \ldots$ C-1

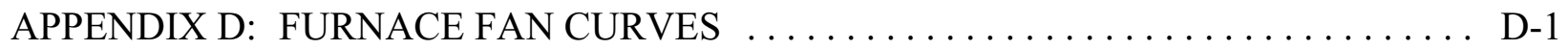

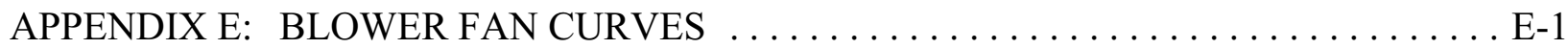
APPENDIX F: OVERALL AIR MOVING EFFICIENCY $\ldots \ldots \ldots \ldots \ldots \ldots \ldots \ldots$ F-1 APPENDIX G: POWER CONSUMPTION OF ECM BLOWER MOTORS . . . . . . . . G-1 APPENDIX H: POWER CONSUMPTION OF BC/ECM+ BLOWER MOTORS . . . . . . H H-1 APPENDIX I: ELECTRICITY AND GAS USE FOR MODULATING FURNACES . . . . . I-1 APPENDIX J: AIR CONDITIONER OPERATING HOURS $\ldots \ldots \ldots \ldots \ldots \ldots \ldots . . . . .1$ 


\section{INTRODUCTION}

The National Appliance Energy Conservation Act of 1987 (NAECA) requires the U.S. Department of Energy (DOE) to consider amendments to the energy conservation standards to increase efficiency in residential furnaces and boilers. This equipment represents a large opportunity for savings because it accounts for 25-30 percent of the total primary energy used in U.S. residential buildings (which was around 21 quads in 2001).

Regulations that took effect in 1992 set the initial Federal energy conservation standard in terms of the Annual Fuel Utilization Efficiency (AFUE) descriptor at a minimum value of $78 \%$ for most furnaces, at $75 \%$ for manufactured-home furnaces, and at $75 \%$ for gas steam boilers and $80 \%$ for other boilers. In 2001, DOE initiated a rulemaking process to consider whether to amend the existing energy efficiency standards for furnaces and boilers. The rulemaking process used by DOE consists of a number of interrelated analytical steps. The Energy Efficiency Standards group at Lawrence Berkeley National Laboratory (LBNL) coordinated and conducted the technical analysis for DOE. ${ }^{1}$

A key factor in DOE's consideration of new standards is their cost-effectiveness to consumers. Determining cost-effectiveness requires an appropriate comparison of the additional first cost of energy efficiency design options with the savings in operating costs. The changes in consumer first cost and operating costs are both measured relative to a base case design. The base case represents the typical type of equipment that consumers would be likely to use in the absence of new standards.

The consumer operating cost has two components: annual energy cost and annual maintenance cost. The annual energy cost is the product of annual energy (gas or oil, and electricity) consumption times the price of each energy type. For the life-cycle cost (LCC) analysis of DOE's rulemaking process, energy consumption was calculated based on estimated conditions in a sample of homes that are representative of expected furnace and boiler installations. This report explains the calculation of energy consumption of furnaces and boilers conducted for the LCC analysis. ${ }^{2}$

The analysis considered six product classes for furnaces and boilers. The level of unit shipments for each class in 2000, based on data provided by the Gas Appliance Manufacturers Association (GAMA), ${ }^{3}$ is shown in Table 1.1. Since non-weatherized gas furnaces comprise by far the largest class, DOE devoted the most attention to this product. 
Table 1.1 Market Statistics for Furnaces and Boilers by Product Class

\begin{tabular}{|l|c|c|}
\hline Product Class & $\begin{array}{c}\text { Estimated } \\
\text { Shipments in 2000 }\end{array}$ & Number of Models (2001) \\
\hline Non-weatherized gas furnaces & $2,645,000$ & 6907 \\
\hline Weatherized gas furnaces & 325,000 & 4476 \\
\hline Non-weatherized oil-fired furnaces & 120,000 & 868 \\
\hline Manufactured-home gas furnaces & 130,000 & 70 \\
\hline Hot water gas boilers & 190,000 & 990 \\
\hline Hot water oil-fired boilers & 100,000 & 640 \\
\hline
\end{tabular}

To represent actual houses with furnaces and boilers in the United States, we used a set of houses from the Residential Energy Consumption Survey of 1997 (RECS97) conducted by the Energy Information Administration (EIA). ${ }^{5}$ For each house, RECS97 reports gas and oil space heating energy consumption and space-cooling electricity consumption. Our calculation methodology estimates the energy consumption of alternative (more-efficient) furnaces, if they were to be used in each house in place of the existing equipment. We developed the method of calculation described in this report for non-weatherized gas furnaces. We generalized the energy consumption calculation for this product class to the other furnace product classes. Fuel consumption calculations for boilers are similar to those for the other furnace product classes. The electricity calculations for boilers are simpler than for furnaces, because boilers do not provide thermal distribution for space cooling as furnaces often do.

\section{FURNACE AND BOILER TECHNOLOGY OVERVIEW}

Fuel-burning furnaces provide heat by transferring combustion products through a heat exchanger. Furnaces pass air over the outside of the heat exchanger, transferring the heat from the fuel to the air. Fuel-burning furnaces exhaust the products of combustion to the atmosphere through the flue passage connected to the heat exchanger. Furnaces use a fan to propel the air over the heat exchanger to circulate the air through the distribution system.

Manufacturers rate non-weatherized furnaces as if they are isolated from the conditioned space where they are located. In this isolated combustion system (ICS) rating, furnaces draw combustion and dilution air from the outdoors. This differs from the "indoors" rating, which assumes that the furnace draws the combustion and dilution air from the conditioned space.

Weatherized furnaces are only used as part of a package unit, which means that the air conditioner is in the same box. They are installed outside (often as a rooftop unit) and are properly insulated. We do not know of any manufacturer that presently sells a stand-alone furnace approved for outdoor installation. The main difference between a weatherized furnace 
and a non-weatherized furnace is that the weatherized furnace has insulation and an external case. Differences in jacket losses also affect test procedure results. The heat loss through the jacket in a weatherized furnace is totally dissipated outside, resulting in a lower efficiency compared to an equivalent non-weatherized furnace installed indoors.

Non-weatherized gas furnaces can be either non-condensing or condensing. Condensing gas furnaces recover so much heat from the combustion products that some of the water vapor condenses and turns into liquid. There are no condensing weatherized furnaces, because the condensate could freeze and damage the furnace. When the flue temperature is substantially higher than the water dew point and the latent heat (the heat from condensation) is lost in the flue, the furnace is classified as non-condensing.

If the furnace condenses the water (typically with the addition of a secondary corrosion-resistant heat exchanger) and drains it out, the flue temperature is much lower, and the efficiency is higher (over $90 \%$ AFUE). ${ }^{a}$ A condensing furnace requires some additional equipment, such as an additional stainless steel heat exchanger and a condensate drain device. Condensing furnaces also require a different venting system, since the buoyancy of the flue gases is not sufficient to draw the gases up a regular chimney. Plastic through-the-wall venting systems are typically used in conjunction with condensing furnaces. Condensing furnaces present a higher initial cost, but provide significant energy savings.

Manufactured home furnaces are a separate class of furnaces, due to three differences. They employ sealed combustion, pre-heat the combustion air, and have very specific geometric configuration. These furnaces have historically had a lower efficiency standard and were considered as a separate product in DOE rulemakings in the early 1990s.

Boilers are heating devices that transfer heat from the combustion gases to water, which then heats up the required space through a hydronic (hot-water) or steam system. The technology used for steam boilers is the same as for hot-water boilers, except that circulating pumps are not used in steam boilers. Boiler capacities range greatly, but they tend to be higher than for furnaces.

Boilers on the market are distinguished by the type of material: cast-iron sectional, steel fire-tube, copper water-tube, and aluminum. Cast-iron boilers are the most popular and are typically gas-fired. Steel boilers are also fairly popular, are perceived to be less expensive, and are always oil-fired. Copper boilers are less popular and are typically used for particular short-response-time small systems. Aluminum boilers are relatively uncommon.

Hot-water boilers are found in all of the above material types. Steam boilers are either cast-iron sectional or steel fire-tube type.

\footnotetext{
${ }^{\text {a }}$ AFUE $=$ Annual Fuel Utilization Efficiency
} 
Table 2.1 shows the current minimum efficiency levels for each product class, as well as the most common efficiency on the market.

Table 2.1 Furnace and Boiler Efficiency

\begin{tabular}{|l|c|c|}
\hline Product Class & Minimum AFUE & $\begin{array}{c}\text { Most Common } \\
\text { AFUE in 2001* }\end{array}$ \\
\hline Non-weatherized gas furnaces & $78 \%$ & $80 \%$ \\
\hline Weatherized gas furnaces & $78 \%$ & $80 \%$ \\
\hline Oil-fired furnaces & $78 \%$ & $81 \%$ \\
\hline Manufactured-home furnaces & $75 \%$ & $80 \%$ \\
\hline Hot water gas boilers & $80 \%$ & $82-83 \%$ \\
\hline Hot water oil-fired boilers & $80 \%$ & $86 \%$ \\
\hline
\end{tabular}

* Based on number of models in GAMA Directory

\section{METHOD FOR NON-WEATHERIZED GAS FURNACES}

To begin the analysis, we developed representative "virtual" furnaces. ${ }^{\text {a }}$ These virtual models incorporated typical features of currently-marketed furnaces. We based the virtual furnaces on models selected from directories and product literature. The virtual models capture the range of actual furnace sizes. We assigned an appropriate virtual furnace to each sample house as a way of modeling energy consumption of alternative furnace designs.

Estimating the energy consumption of alternative furnaces used in each house required derivation of the heating and cooling loads of each house. These loads represent the amount of heating and cooling required by a house to keep it comfortable during an entire year. We estimated the heating and cooling loads from the heating and cooling energy consumption and the assumed characteristics of the existing furnace and air conditioner in each sample house. We assigned the characteristics of the existing furnace and air conditioner to each sample house, depending on the size and climate zone of each house and the age of the heating equipment. The estimation of heating and cooling loads also required us to calculate the electricity consumption of the furnace blower, since heat from the furnace blower and blower motor contributes to heating the house.

To complete the analysis, we calculated how much energy would be required by furnaces with alternative efficiency levels and design options to meet the same heating and cooling load of each sample house.

\footnotetext{
a We use the term "virtual" to indicate that these are conceptual furnaces rather than actual furnaces on the market.
} 


\section{VIRTUAL FURNACE MODELS}

We intended the virtual furnace models to represent typical furnaces with basic features, but not to describe specific existing furnaces. We derived the characteristics of the virtual furnace models from existing "basic" furnace models, after examining directories and product literature of existing furnaces. See Appendix A, Database of Reduced Set of Furnace Models, for more details.

As a starting point for choosing values of input capacity for the virtual furnace models, we looked at the number of models listed by input capacity in the GAMA Directory of April $2002^{4}$ (see Figure 4.1). We selected models that were non-weatherized gas furnaces not designed for manufactured homes, and that were not discontinued. Using these selection criteria, we reduced the 36,032 gas furnace models in the GAMA Directory to 15,881 models. For virtual furnaces, we selected twelve input capacities that were the most common and that spanned the range on the market. We made these selections based on the assumption that the sizes with the most models are the most popular (see Table 4.1).

We defined airflow capacity as the nominal maximum airflow at 0.5 inches water gauge (in.w.g.) external static pressure, as listed in the product literature for each model. ${ }^{\text {a }}$ Manufacturers usually code this airflow capacity in the model number. (See Appendix B, Manufacturer Model Numbers, for more details.) Most of the furnaces fit into four airflow capacity sizes: 800 cubic feet per minute $(\mathrm{cfm}), 1200 \mathrm{cfm}, 1600 \mathrm{cfm}$, and $2000 \mathrm{cfm}$. These airflow capacities correspond to nominal air-conditioner sizes of two tons, three tons, four tons, and five tons, respectively. We used the same set of airflow and capacity sizes for both noncondensing and condensing furnaces.

\footnotetext{
${ }^{\text {a }}$ Furnaces are capable of providing several levels of airflow. For heating operation, a low level of airflow is used. If the furnace provides airflow for an air conditioner during cooling operation, it is typically set to provide a higher level of airflow when the air conditioner is operating.
} 


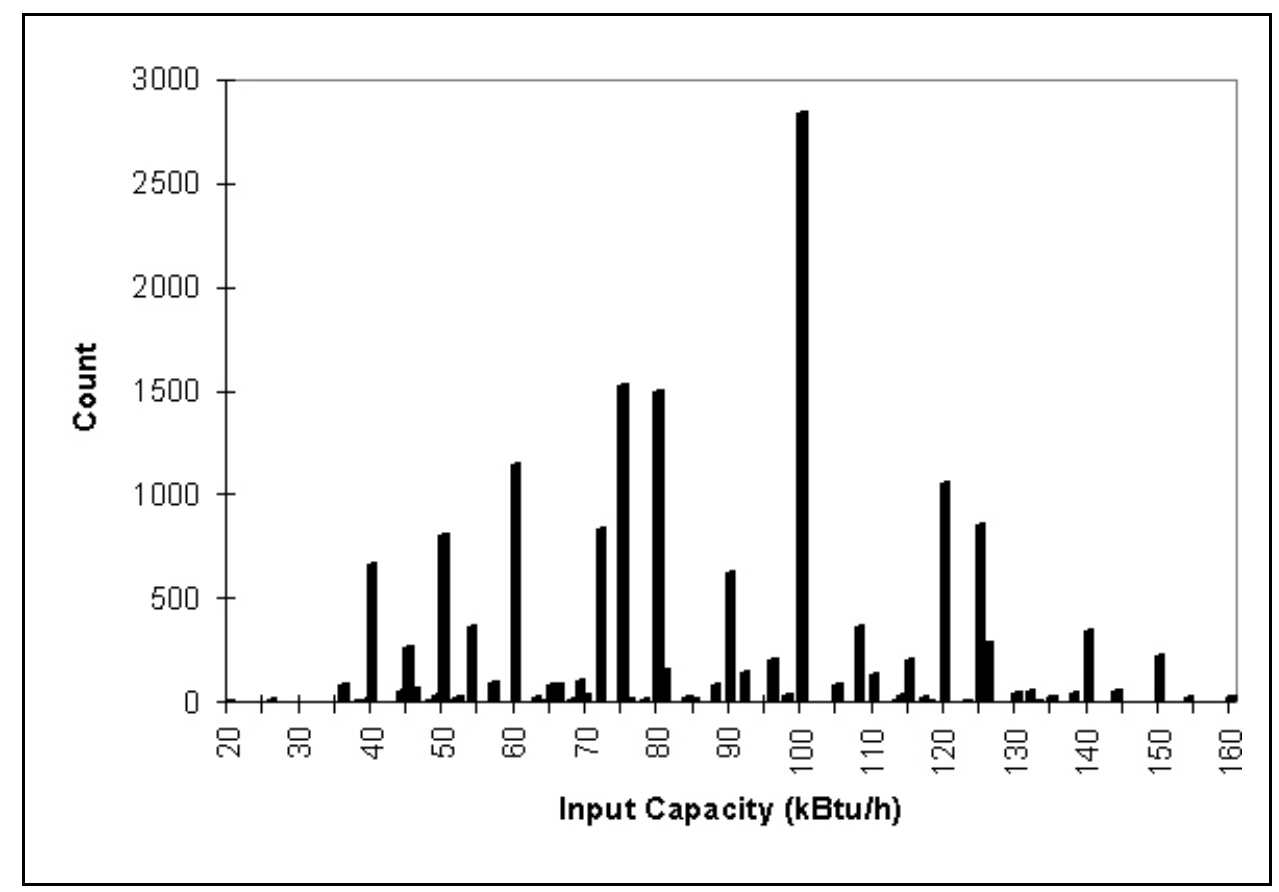

Figure 4.1 Number of Furnace Models by Input Capacity

\subsection{Basic Actual Furnace Models}

We selected actual furnace models that represent the fundamental characteristics of noncondensing and condensing furnaces with no special features. We used the characteristics listed in Table 4.1 to select basic furnace models. These characteristics are the most common among models on the market. We selected several dozen furnace models that have these features and looked in detail at these basic models to determine specific characteristics to use for creating virtual furnaces.

Table 4.1 Characteristics of Basic Furnace Models

\begin{tabular}{|c|c|}
\hline Non-Condensing Gas Furnace & Condensing Gas Furnace \\
\hline single-stage burner & single-stage burner \\
\hline $80 \%$ AFUE & $90-92 \%$ AFUE \\
\hline PSC blower motor & PSC blower motor \\
\hline forward-curved fan impeller blades & forward-curved fan impeller blades \\
\hline up-flow or horizontal air-flow & down-flow, up-flow, or horizontal air-flow \\
\hline
\end{tabular}


The basic furnace models are listed by brand and series in Appendix C, Basic Furnace Model Determination.

\subsection{Input Capacity and Maximum Airflow}

For virtual furnace models, we selected 25 combinations ("bins") of input capacity and maximum airflow. The marked cells in Table 4.2 reflect the input capacity and maximum airflow values for the virtual furnace models. The selection reflects the most common input and nominal maximum airflow capacities of models in the GAMA Directory April 2002 database, in product literature, and listed on furnace manufacturer web sites. Most basic models on the market fit into the 25 bins of input capacity and airflow capacity. Some models do not exactly match the bins, but their values are close enough that we included them in one of the 25 bins. For example, 40 $\mathrm{kBTU} / \mathrm{h}$ and $45 \mathrm{kBTU} / \mathrm{h}$ models are grouped together into a single $45 \mathrm{kBTU} / \mathrm{h}$ bin. Most bins have at least two actual models.

\section{Table 4.2 Virtual Furnaces: Capacity and Airflow}

\begin{tabular}{|c|c|c|c|c|c|c|c|c|c|c|c|c|c|}
\hline & & \multicolumn{12}{|c|}{ Input Capacity (kBTU/h) } \\
\hline \multirow{5}{*}{ 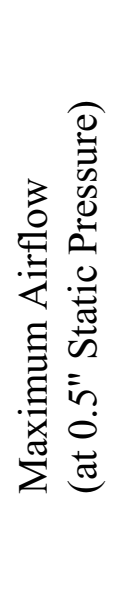 } & & 45 & 50 & 60 & 70 & 75 & 80 & 90 & 100 & 115 & 120 & 125 & 140 \\
\hline & $\begin{array}{l}800 \mathrm{cfm} \\
(2 \text { tons })\end{array}$ & $\mathrm{X}$ & $\mathrm{X}$ & $\mathrm{x}$ & & & & & & & & & \\
\hline & $\begin{array}{c}1200 \mathrm{cfm} \\
(3 \text { tons })\end{array}$ & $\mathrm{x}$ & $\mathrm{X}$ & $\mathrm{x}$ & $\mathrm{X}$ & $\mathrm{x}$ & $\mathrm{x}$ & $\mathrm{x}$ & $\mathrm{x}$ & & & & \\
\hline & $\begin{array}{c}1600 \mathrm{cfm} \\
(4 \text { tons })\end{array}$ & & & & $\mathrm{x}$ & $\mathrm{X}$ & $\mathrm{x}$ & $\mathrm{x}$ & $\mathrm{x}$ & $\mathrm{x}$ & $\mathrm{x}$ & $\mathrm{x}$ & \\
\hline & $\begin{array}{c}2000 \mathrm{cfm} \\
(5 \text { tons })\end{array}$ & & & & & & & $\mathrm{x}$ & $\mathrm{x}$ & $\mathrm{x}$ & $\mathrm{x}$ & $\mathrm{x}$ & $\mathrm{X}$ \\
\hline
\end{tabular}

Because of the limited number of sizes available for manufactured-home gas furnaces and oil-fired furnaces, we selected a subset of the 25 input and airflow capacity combinations to represent each product class.

We created one virtual model to represent all the models assigned to each bin. We used specifications from the actual models in each bin to determine the specifications for the corresponding virtual model. The specifications include blower size, motor size, supply-air outlet area, power consumption of the draft inducer and the igniter, and several delay times. These specifications are described in the sections below. 


\subsection{Blower Size}

We selected a blower size (listed as nominal diameter in inches by nominal width in inches) for each virtual furnace model (see Table 4.3). The blower size is typical for the basic furnace models in each bin. Blower size increases with airflow capacity, but not with input capacity. We used four blower sizes - the same ones for condensing and non-condensing virtual furnace models. For the blower sizes of basic furnace models, see Appendix C.

Table 4.3 Assigned Blower Size by Airflow Capacity

\begin{tabular}{|l|c|}
\hline Airflow Capacity $(\mathbf{c f m})$ & Blower Size (inches) \\
\hline 2-ton models $(800 \mathrm{cfm})$ & $9 \times 8$ \\
\hline 3-ton models $(1200 \mathrm{cfm})$ & $10 \times 8$ \\
\hline 4-ton models $(1600 \mathrm{cfm})$ & $10 \times 10$ \\
\hline 5-ton models $(2000 \mathrm{cfm})$ & $11 \times 10$ \\
\hline
\end{tabular}

\subsection{Motor Size}

The motors for the basic furnace models are 6-pole permanent split capacitor (PSC) motors. The motors in the basic furnaces come with three to five taps that are used to set the motor speed. We assumed that, at high speed, the motors operate with a speed of 1075 revolutions per minute (rpm) to provide the nominal maximum airflow at 0.5 in.w.g.

We assigned motor size to virtual furnace models, as shown in Table 4.4, to reflect typical-size motors of the basic furnace models. Motor sizes are the same for non-condensing and condensing furnaces. The larger the airflow, the larger the motor size. For the blower motor size and number of blower motor taps of basic model furnaces, see Appendix C.

Table 4.4 Assigned Motor Size by Airflow Capacity

\begin{tabular}{|l|c|}
\hline Airflow Capacity $(\mathbf{c f m})$ & Motor Size (HP) \\
\hline 2-ton models $(800 \mathrm{cfm})$ & $1 / 5$ \\
\hline 3-ton models $(1200 \mathrm{cfm})$ & $1 / 3$ \\
\hline 4-ton models $(1600 \mathrm{cfm})$ & $1 / 2$ \\
\hline 5-ton models $(2000 \mathrm{cfm})$ & $3 / 4$ \\
\hline
\end{tabular}




\subsection{Supply-Air Outlet Area}

The supply-air outlet area is the opening from the furnace to the supply duct. The supplyair outlet area for basic furnace models increases with airflow capacity and input capacity. To capture this trend, we constructed a linear fit of the supply-air outlet area to input capacity and airflow capacity for condensing and non-condensing furnaces. See Appendix C for supply-air outlet areas of basic furnace models. We used the following equations to determine the supplyair outlet area of the condensing and non-condensing virtual furnace models:

$$
\begin{aligned}
& S n c=0.9498+0.5505 \times(\mathrm{Q} / 1000)+0.0073 \times(\mathrm{Qin}) \\
& S c=0.7882+0.5006 \times(\mathrm{Q} / 1000)+0.0087 \times(\mathrm{Qin})
\end{aligned}
$$

where:

$\mathrm{S} \quad=$ supply-air outlet area (sq. ft.) for non-condensing $(n c)$ and condensing $(c)$;

$\mathrm{Q}=$ nominal maximum airflow (cfm) at 0.5 in.w.g. static pressure; and

Qin = input capacity $(\mathrm{kBtu} / \mathrm{h})$.

Figures 4.2 and 4.3 show the data points for supply-air outlet area for basic furnace models and the linear plane fit used to fit these points. 


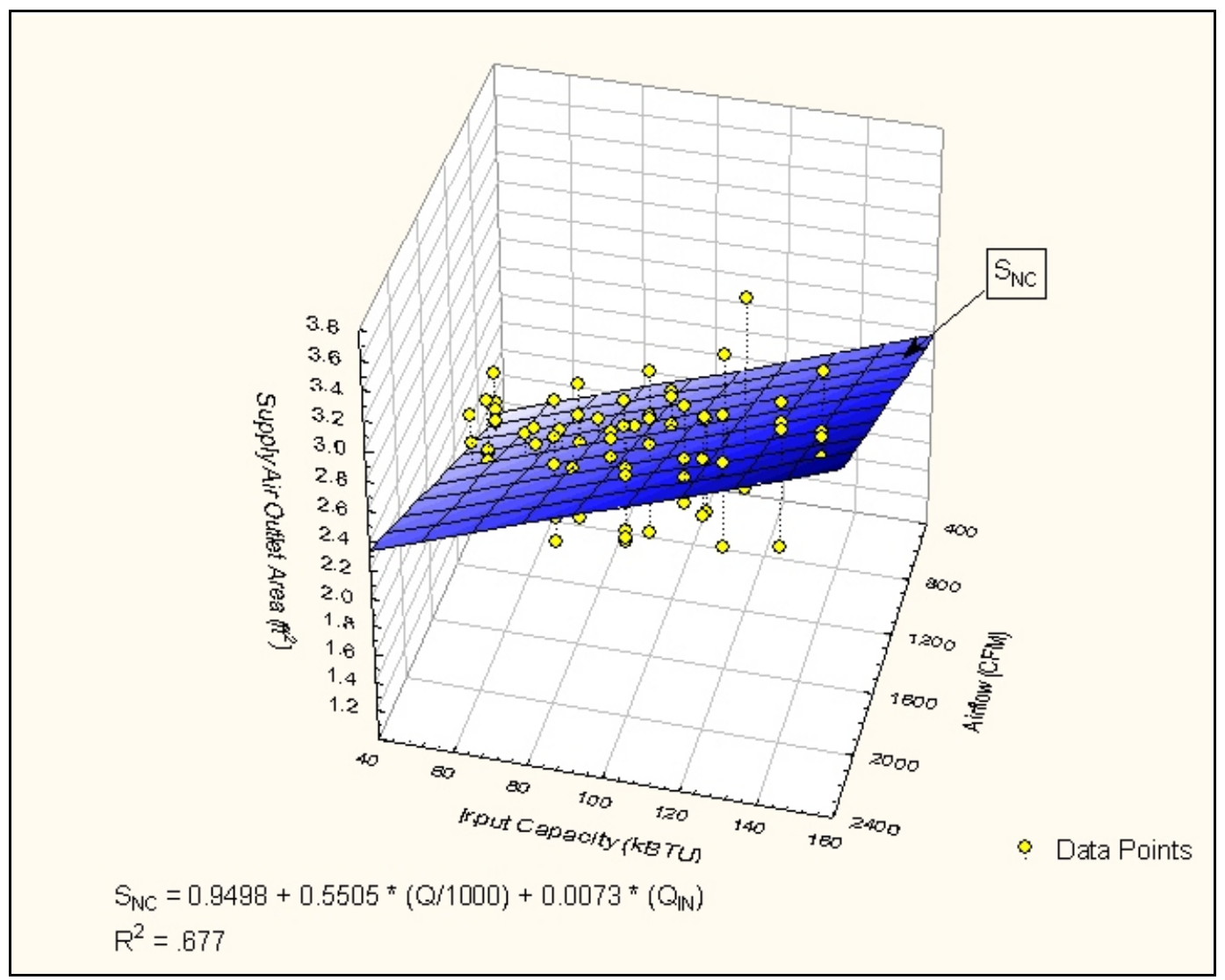

Figure 4.2 Supply-Air Outlet Area for Non-Condensing Natural Gas

Furnaces 


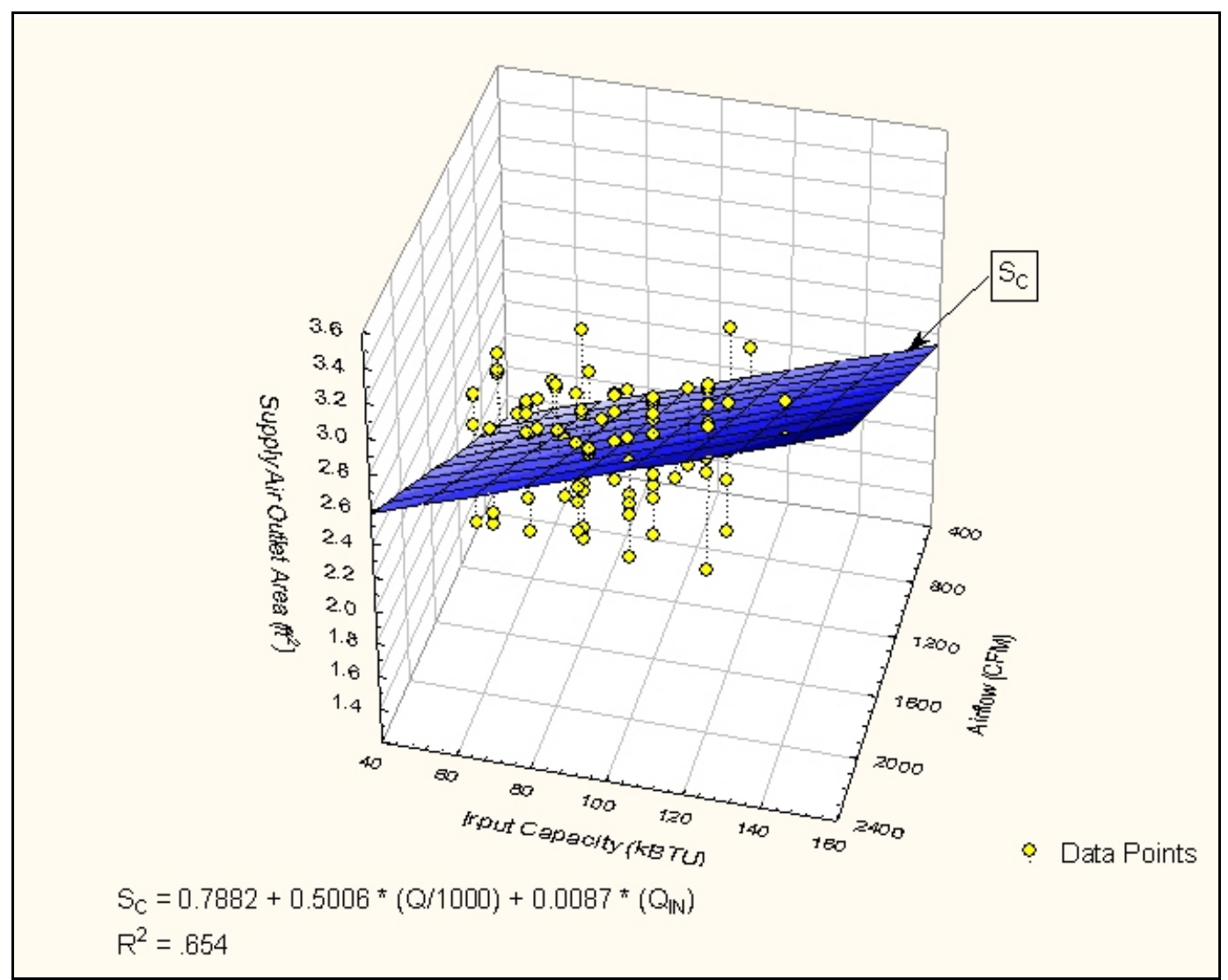

Figure 4.3 Supply-Air Outlet Area for Condensing Natural Gas Furnaces

Tables 4.5 and 4.6 show the values used for supply-air outlet areas for non-condensing and condensing virtual gas furnaces. The supply-air outlet area is larger for condensing models. The larger opening compensates for the increased pressure drop due to the secondary, condensing heat exchanger. This larger supply-air outlet area reduces the pressure drop across the furnace, so that the pressure rise for condensing furnaces is the same as non-condensing model furnaces at the same airflow. 
Table 4.5 Supply-Air Outlet Area for Virtual Non-Condensing Gas Furnace Models

Input Capacity (kBTU/h)

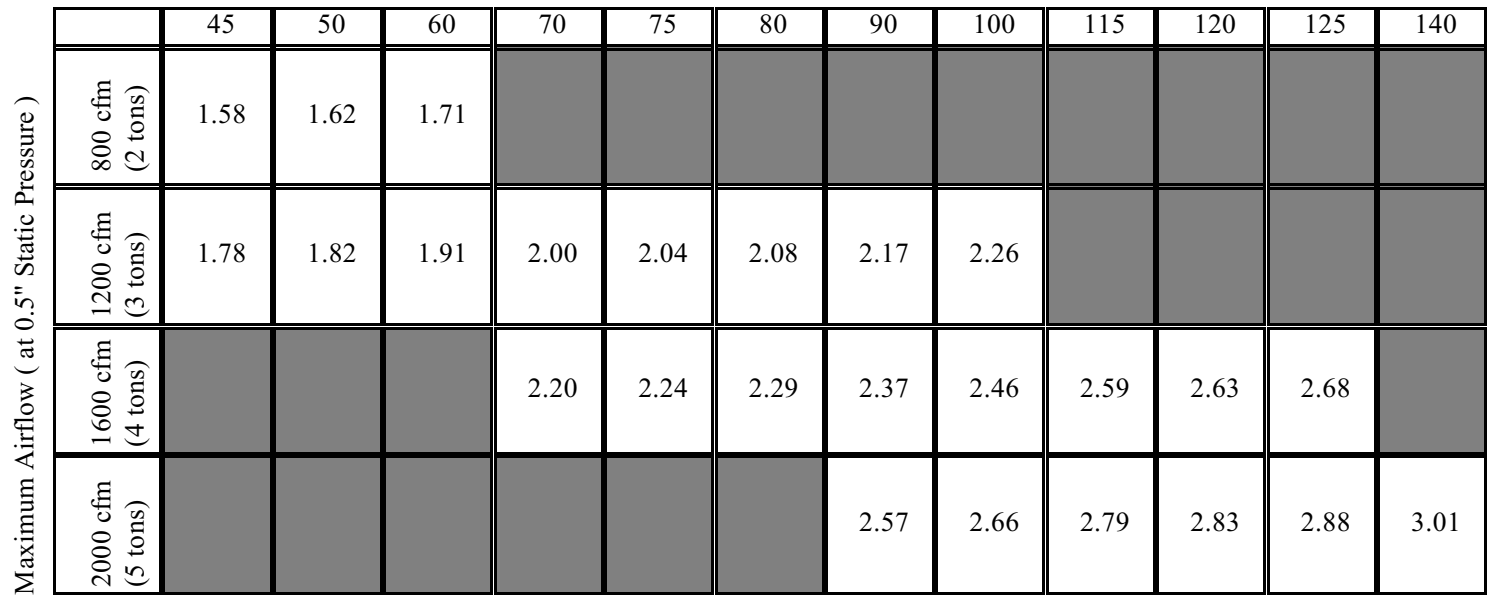

Table 4.6 Supply-Air Outlet Area for Virtual Condensing Gas Furnace Models

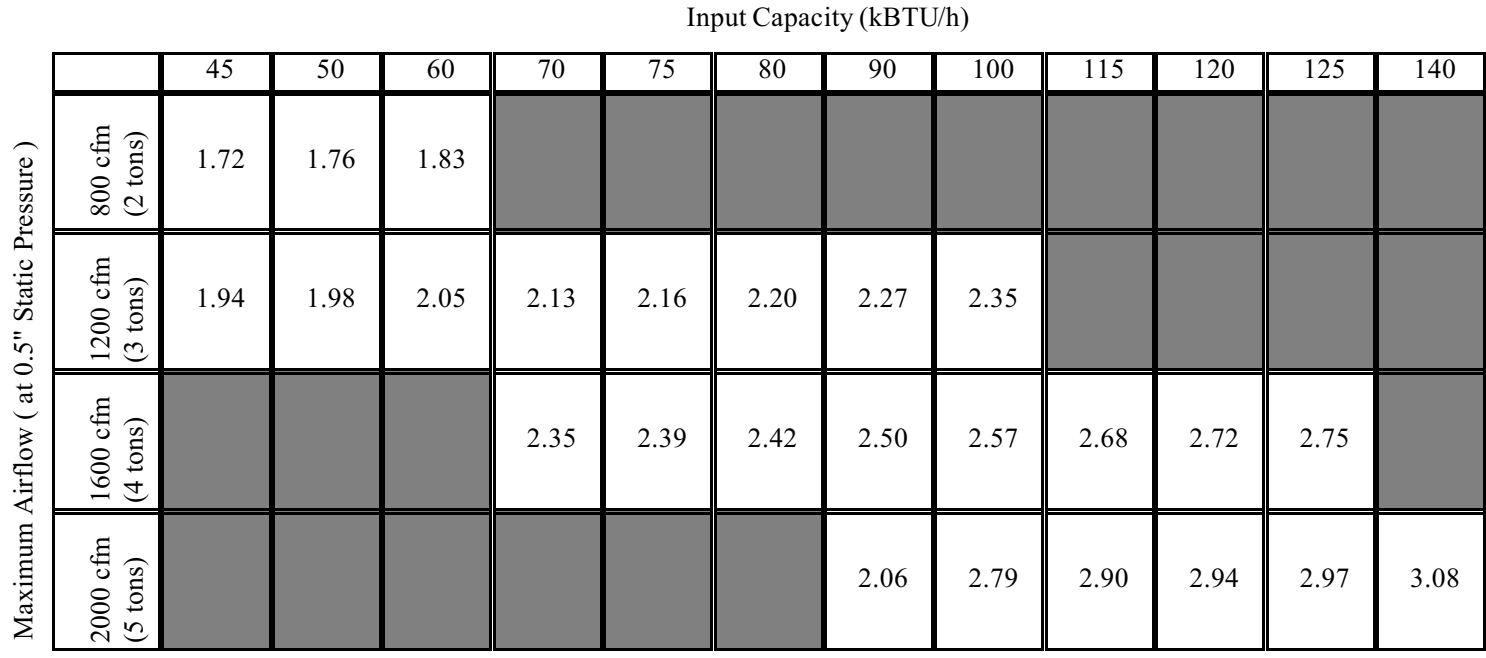

\subsection{Power Consumption of Draft Inducer}

A common value for power consumption of the draft inducer (PE) for basic non-condensing model furnaces is $75 \mathrm{~W}$, and the average value is about $75 \mathrm{~W}$, so we selected 75 $\mathrm{W}$ for all the virtual non-condensing models. We found no correlation between the power consumption of the draft inducer and either input capacity or airflow capacity. For condensing furnaces, we used a PE of $90 \mathrm{~W}$, which closely matches the mean for that group. See Appendix $\mathrm{C}$ for the power consumption of the draft inducer in the basic models. 


\subsection{Delay Times}

Pre- and post-purge times are the lengths of time the draft inducer operates before and after a firing cycle. On-delay is the amount of time the blower waits to begin operating after the burner starts firing. Off-delay is the time the blower keeps operating after the burner turns off. Ignition time is the length of time the hot surface ignitor is on before gas is sent to the burner.

Pre-purge, post-purge, on-delay, and off-delay times are not related to $\mathrm{cfm}$ or input capacity. We selected common values for the delay and ignition times of condensing and non-condensing virtual furnace models (Table 4.7). For this data for basic furnace models, see Appendix C.

Table 4.7 Values for Delay and Ignition Times

\begin{tabular}{|c|c|c|c|c|}
\hline Pre-Purge & Post-Purge & On-Delay & Off-Delay & Ignition \\
\hline 15 seconds & 5 seconds & 30 seconds & 120 seconds & 37 seconds \\
\hline
\end{tabular}

\section{ASSIGNING EXISTING EQUIPMENT TO SAMPLE HOUSES}

To estimate the heating and cooling load of each sample house, we characterized the existing furnace in each sample house with respect to input capacity, airflow capacity, AFUE, and (for the air conditioner, if the house has one), seasonal energy efficiency ratio (SEER). As part of the heating- and cooling-load calculations, we estimated the electricity consumption and efficiency of the furnace blower motor. We used the input capacity and airflow capacity determined for the existing furnace to select the virtual furnace model to assign to each house.

\subsection{Furnace Input Capacity}

We assigned an input capacity for the existing furnace of each house based on an algorithm that correlates input capacity with the house size, the year the furnace was installed, and the distribution of input capacity of new furnaces sold the year the furnace was installed. The following steps describe the assignment process.

(1) We ranked all the RECS97 houses in ascending order by size (square foot) and calculated the percentile rank of each house using the weight of the sample records.

(2) We constructed percentile tables by input capacity of furnaces sold each year for 1997 and prior years, based on the historical shipment information for each year from GAMA. ${ }^{3}$

(3) After selecting a house from the RECS97 database during each Monte Carlo iteration, we noted the size of the selected house and determined the percentile rank from Step 1.

(4) To avoid a one-to-one deterministic relation between the house size and input capacity, we added a random term to the percentile identified in Step 3 so that the correlation was not perfect. We used a normal distribution to characterize the random term. The random 
(5) Using the percentile from Step 4, we looked up the input capacity from the input capacity percentile table in Step 2 for the age of the equipment.

Figure 5.1 shows the percent of existing furnaces by the input capacity assigned to the sample houses.

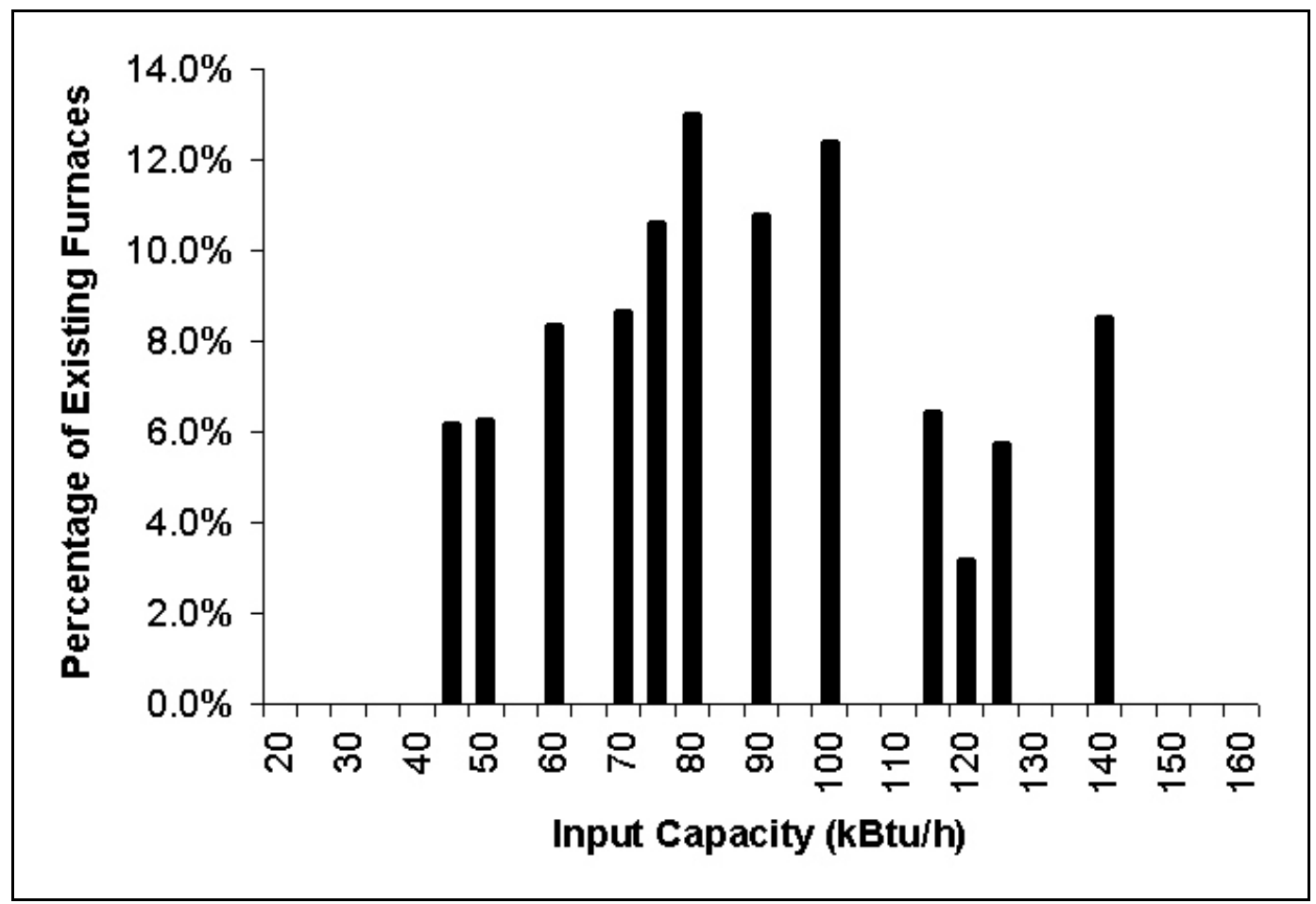

Figure 5.1 Percent of Existing Furnaces by Input Capacity

\subsection{Airflow Capacity}

We classified furnaces by nominal maximum airflow in cfm at 0.5 in.w.g. of external static pressure. We assigned the airflow capacity of existing furnaces for houses that had air conditioners in a similar manner as we assigned input capacity. Larger air conditioners go to larger houses, according to the distribution of sizes of air conditioners sold the year the air conditioner was installed in that house. We used the air conditioner nominal size of two, three, four, or five tons to set the airflow capacity with a ratio of $400 \mathrm{cfm}$ of airflow per ton of cooling. The steps were:

(1) Based on the historical shipment information of residential central air conditioners by capacity, we constructed the airflow capacity percentiles tables for air conditioners sold in 1997 and prior years. We restricted the airflow sizes to two, three, four, or five tons - the equivalent of $800,1200,1600$, or $2000 \mathrm{cfm}$ at $0.5 \mathrm{in.w.g}$. static pressure. The variation of 
the distribution of the four airflow sizes over the years is small. Most of the annual sales of residential central air conditioners from 1976 to 1994 are in these airflow sizes.

(2) Since there are no available shipment data on the airflow capacity of furnaces, we used the airflow capacity of residential central air conditioners as a proxy. Using the adjusted percentile of house size from Step (4) in the Input Capacity selection, we determined the airflow capacity by looking up the percentile in the corresponding distribution of nominal air conditioner size for the age of the cooling equipment. We selected a virtual model with the identified airflow capacity. If no virtual model with the identified airflow capacity was available, we selected the virtual model with the same input capacity and the closest airflow capacity as a substitute.

(3) If the RECS record indicated that the house did not have an air conditioner, we still used the procedure from step (2) to determine the airflow capacity. In this case, we used the age of the house (or 30 years if the house was older than 30 years) as a substitute for the age of the cooling equipment.

\subsection{Efficiency Characteristics of Existing Equipment}

Shipments data from GAMA indicate that houses in colder regions receive more-efficient furnaces. ${ }^{3}$ Therefore, we correlated the AFUE of existing furnaces with the heating degree days (HDD) to base $65^{\circ} \mathrm{F}$ associated with each sample house. The following steps describe this process:

(1) We sorted the RECS houses in ascending order of HDDs, and calculated the percentile rank of each house by HDD using the weight of each sample house.

(2) Based on the historical furnace shipment information sorted by AFUE, we constructed percentile tables of furnaces by AFUE for 1997 and prior years.

(3) After we selected a house from the RECS database during each Monte Carlo iteration, we noted the HDD of the selected house. We looked up the percentile rank of that house from the HDD percentile table developed in Step (1).

(4) We added a random uncertainty term to the HDD percentile found in Step (3) to account for variability within the sample. We used a normal distribution to characterize the uncertainty term. The distribution of values of the uncertainty term has a mean of zero and a standard deviation of $8 \%$.

(5) Using the adjusted HDD percentile from Step (4), we determined the AFUE by looking it up from the AFUE percentile table from Step (2) corresponding to the age of the existing equipment in the house.

Houses with central air conditioners use the circulating-air blower in the furnace to circulate the conditioned air during the cooling season. If a house had an air conditioner, we assigned it a SEER level. Unlike AFUE, SEER was not correlated with any other housing factors. We constructed SEER distributions for all years from historical shipment data, and we randomly selected a SEER from the distribution for the year of the age of equipment in each house. 


\subsection{Electricity Consumption of Existing Furnace Blower}

All furnaces manufactured since about 1980 use forward-curved impellers driven directly by a PSC motor. Thus, most existing furnaces have a blower and blower motor similar to those in the virtual furnace models. ${ }^{a}$ Therefore, in assigning the electricity consumption of the existing furnace blower for each house, we assumed that the electricity use of the existing furnace was equivalent to the electricity use of the virtual furnace model described in section 3.

We calculated electricity use by the existing furnace from the fan curves, overall efficiency, airpower, and time delays of the virtual furnace model of the same input capacity and airflow capacity. The calculation procedure used is described below.

\section{CALCULATING FURNACE BLOWER ELECTRICITY CONSUMPTION}

The electricity consumption (and overall efficiency) of a blower motor depends on the speed at which the motor operates, the external static pressure difference across the blower, and the airflow through the blower. To calculate blower-motor electricity consumption, we determined the operating conditions (the pressure and airflow) at which a particular furnace in a particular house will operate. These operating conditions can be graphically displayed as the intersection of a system curve of the ducts in the house (which plots the static pressure across the supply and return air ducts as a function of airflow) with the fan curve of the furnace (which plots the static pressure across the furnace as a function of airflow). The intersection of these two curves is the static pressure and the airflow at which the furnace will operate in that house (refer to Figure 6.1).

Furnace fan curves, reported as tables of static pressure rise versus airflow through the furnace, are available from manufacturers in the product literature for each furnace. One of the manufacturers also supplies blower-motor input power as a function of airflow through the furnace.

Air power is calculated from the air speed through the furnace and the pressure rise across the furnace. The overall air-moving efficiency is air power divided by the electric power to the blower. All the electric power to blower motors eventually is converted to heat that contributes to meeting the building heating load.

\footnotetext{
${ }^{a}$ A very small share of existing furnaces use belt-drive blowers with shaded-pole motors. That arrangement was less efficient than direct-driven PSC motors, but the airflow from these old model furnaces was less, so electricity consumption was not significantly reduced when this technology became obsolete.
} 


\subsection{System Curves}

The system curve of the air-distribution system is a graphical representation of the static pressure drop generated across the supply and return ducts in a house for different airflows. The airflow and pressure drop at which the furnace will operate can be determined by the intersection of the system curve of the house and the fan curve of the furnace circulating air blower ${ }^{4}$.

We modeled system curves as quadratic curves, which is standard in HVAC design and fan selection books ${ }^{6}$. The curves are based on Bernoulli's equations for fluid flow and are expressed as the following equation:

where;

$$
P=a \times Q^{2}
$$

$$
\begin{array}{ll}
P & =\text { static pressure (in.w.g.); } \\
\alpha & =\text { a constant coefficient; and } \\
Q & =\text { airflow }(\mathrm{cfm}) .
\end{array}
$$

We selected the coefficient in the system curve equation for each house. It randomly sampled a coefficient from one of four distributions, depending on the nominal maximum airflow of the virtual model furnace selected for that house. We designed each distribution so that $10 \%$ of samples would have static pressures below $0.5 \mathrm{in.w.g.,} \mathrm{and} \mathrm{only} 1 \%$ of the samples would have static pressures greater than 1 in.w.g at the nominal maximum airflow. This is in line with several field studies. ${ }^{7}$ To keep the system curves from clumping at the higher pressures, we used a log-normal distribution of values of the coefficient. See Figure 6.1 for an example of a plot of system curves intersecting a furnace fan curve. 


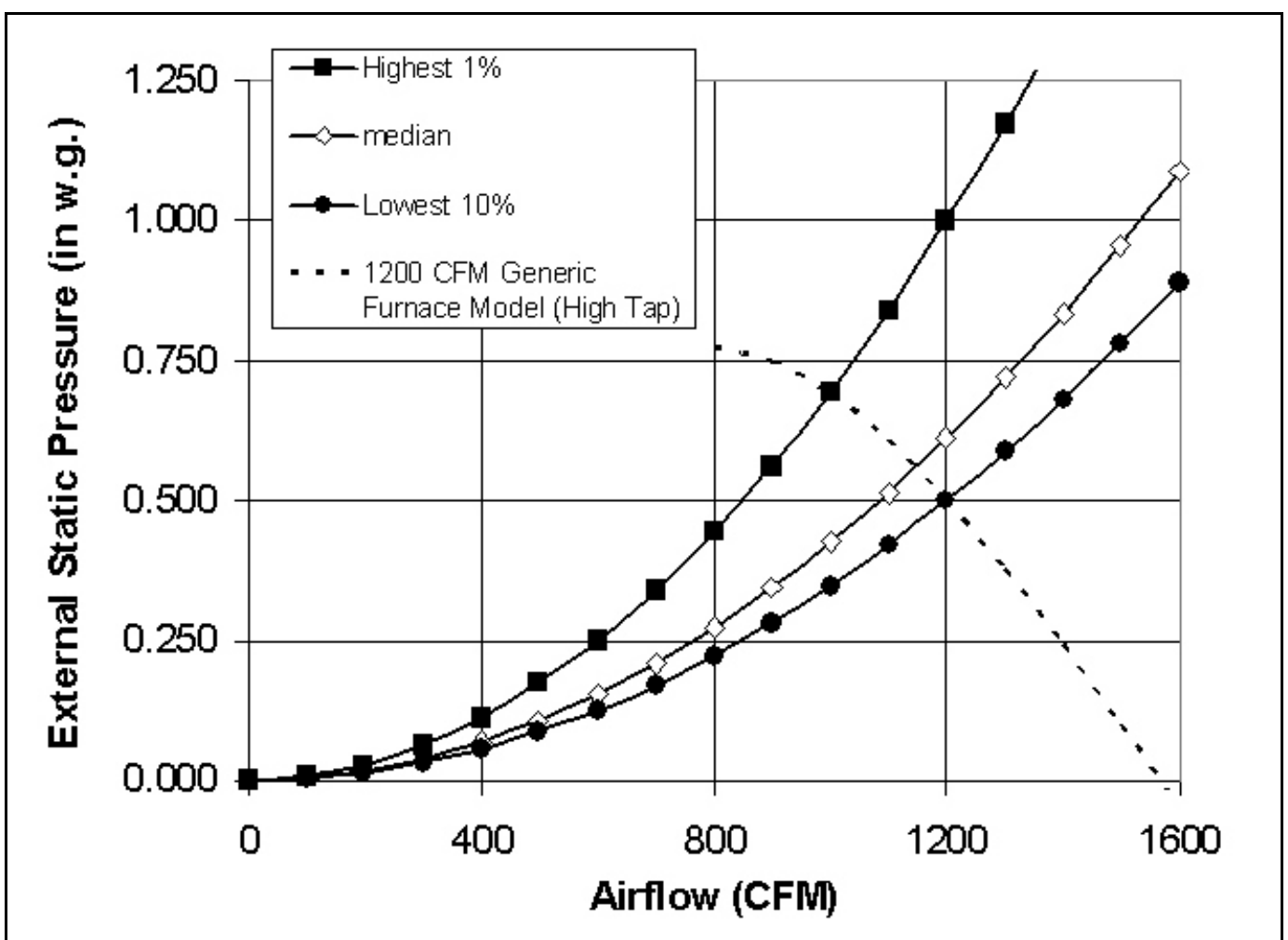

Figure 6.1 Sample of System Curves with a Typical Fan Curve

\subsection{Furnace Fan Curves}

Depending on the resistance (measured as static pressure at a give flow) of the supply and return air ducts, a furnace will move more or less air through the ducts. When these values are plotted graphically, they are referred to as fan curves.

We assigned three fan curves to each virtual furnace model: one for cooling operation, one for heating, and a third for the low-fire heating operation of modulating design options. The cooling fan curve passes through the nominal maximum-rated airflow point at 0.5 in.w.g. external static pressure. During normal heating operation, airflow is $80 \%$ of the nominal maximum airflow at 0.5 in.w.g. external static pressure. The airflow for low-fire heating operation at 0.5 in.w.g. static pressure is $2 / 3$ of the nominal maximum airflow at the same external static pressure.

We developed fan curves for the virtual furnace models. As detailed in Appendix D, Furnace Fan Curves, Figures 6.2-6.5 show the fan curves for the virtual furnace models. From the left, the line closest to vertical axis shows a fan curve for the virtual furnace model operating in low-fire mode, the middle line is for the virtual furnace model operating in heating mode, and the line furthest to the right, which passes through $0.5 \mathrm{in}$. w.g. static pressure at the nominal maximum of airflow, is the fan curve for the virtual furnace models operating in cooling mode. 


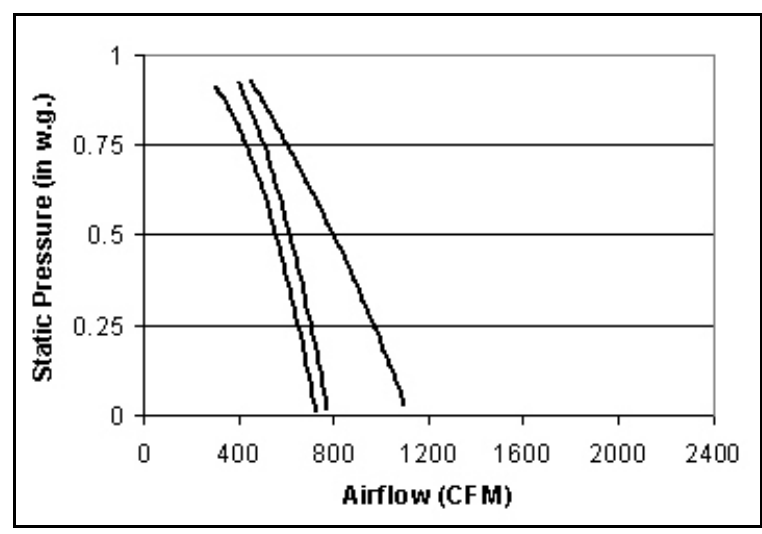

Figure 6.2 Fan Curves for $800 \mathrm{cfm}$ Virtual Furnace Model

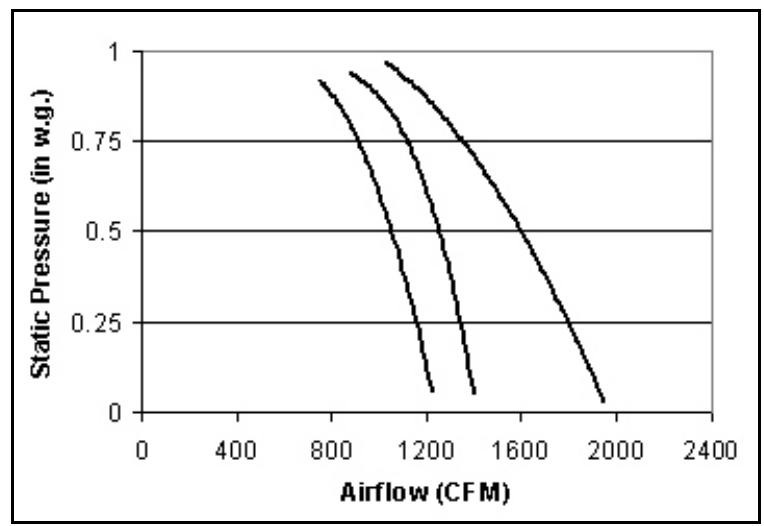

Figure 6.4 Fan Curves for $1600 \mathrm{cfm}$ Virtual Furnace Model

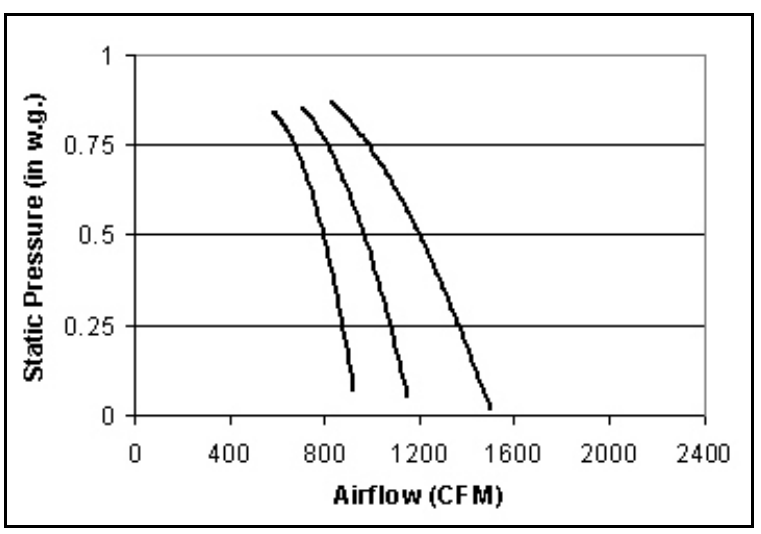

Figure 6.3 Fan Curves for $1200 \mathrm{cfm}$ Virtual Furnace Model

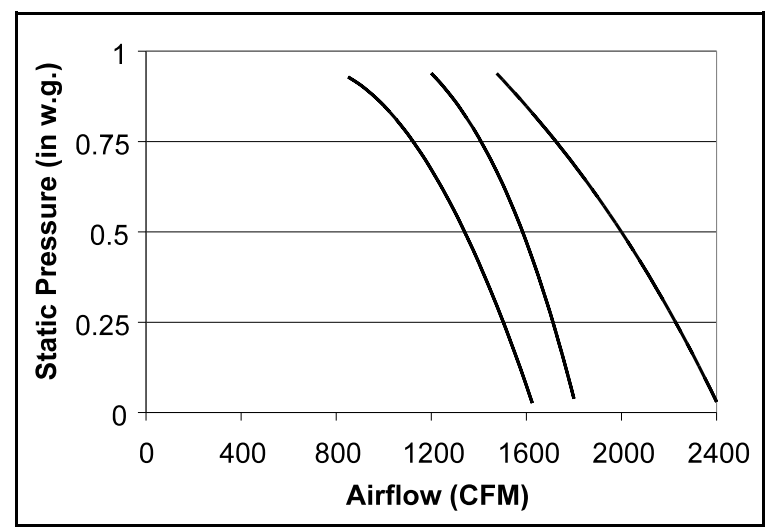

Figure 6.5 Fan Curves for $2000 \mathrm{cfm}$ Virtual Furnace Model

\subsection{Overall Air-Moving Efficiency}

The overall air-moving efficiency is the air power divided by the electric power used by the blower motor.

Air power, the power added to the air because of its motion and pressure increase as it is forced through the furnace, is calculated as:

$$
A P=\left(\frac{7457}{6356}\right) \times Q \times\left[P+\left(\frac{Q}{4005 \times A}\right)^{2}\right]
$$

where; 


$$
\begin{array}{lll}
A P & = & \text { air power (watts); } \\
Q & = & \text { airflow (cfm); } \\
\frac{745.7}{6356} & = & \text { a conversion factor to put air horsepower in watts; } \\
4005 & = & \text { a conversion factor to put the velocity pressure of standard air in } \\
P & & \text { i.w.g.; } \\
A & = & \text { external static pressure (in.w.g.); and } \\
& & \text { cross-sectional airflow area defined as a supply-air outlet area } \\
& & \text { (sq.ft.). }
\end{array}
$$

In addition to airflow at a range of external static pressures one manufacturer reports fan motor electricity consumption as well. . $^{8,10,11,12,13}$ This allowed us to calculate the overall efficiency from data in that manufacturers' product literature.

$$
\text { noverall }=\frac{A P}{B E}
$$

where;

$$
\begin{array}{lll}
\eta_{\text {overall }} & = & \text { overall air moving efficiency; } \\
B E & = & \text { fan motor electricity consumption }(\mathrm{W}) ; \text { and } \\
A P & = & \text { air power }(\mathrm{W}) .
\end{array}
$$

We calculated air power and overall efficiency for each point in the fan operating tables for each of the models. To generalize this relation of overall air-moving efficiency to airflow, we transformed airflows to percentages of airflow at free flow for all the furnaces. We did this calculation separately for condensing and non-condensing furnaces. The transformation of airflow to fraction-of-airflow-at-free-flow allowed us to plot all of the curves of overall airmoving efficiency together (see Figure 6.6). 


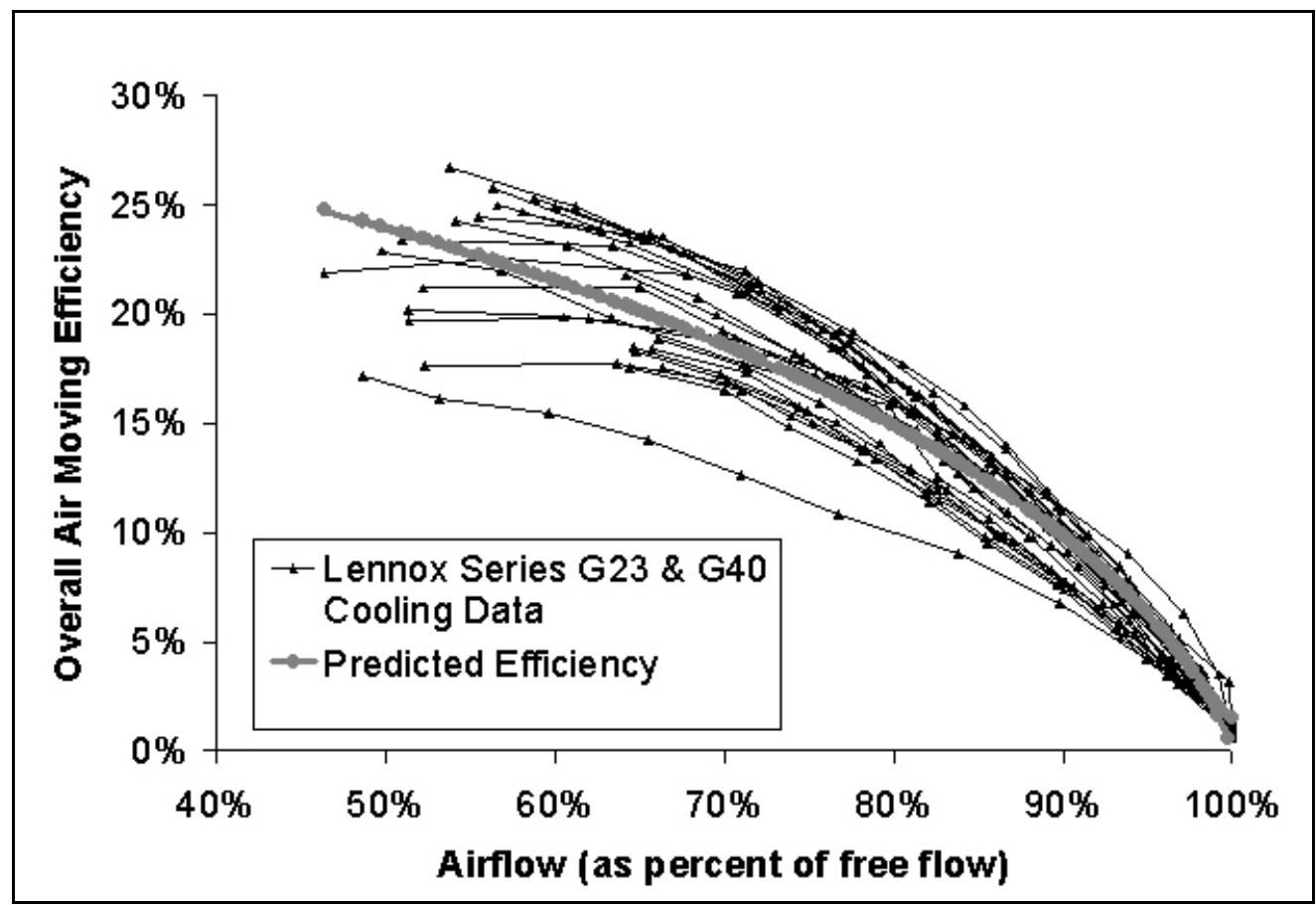

Figure 6.6 Overall Air-Moving Efficiency of Existing Furnaces

We fit these curves to a single equation of overall efficiency as a function of the ratio of airflow to free airflow as follows:

where;

$$
\eta_{\text {oerall }}=c_{0}+c_{1} \times\left(1-Q_{0}\right)+c_{2} \times\left(1-Q_{0}\right)^{(1 / 2)}+c_{3} \times\left(1-Q_{0}\right)^{(1 / 3)}
$$

$$
\begin{array}{lll}
\eta_{\text {averall }} & = & \text { overall air moving efficiency; } \\
Q_{0} & = & \text { ratio of airflow to free flow; and } \\
c_{0}, c_{1}, c_{2}, c_{3} & = & \text { empirically determined coefficients. }
\end{array}
$$

Figures 6.7 and 6.8 show the overall air-moving efficiency for non-condensing and condensing virtual furnace models. For details of the overall air-moving efficiency and tables of coefficients for each of the virtual furnaces and operating modes, see Appendix F, Overall Air Moving Efficiency. 


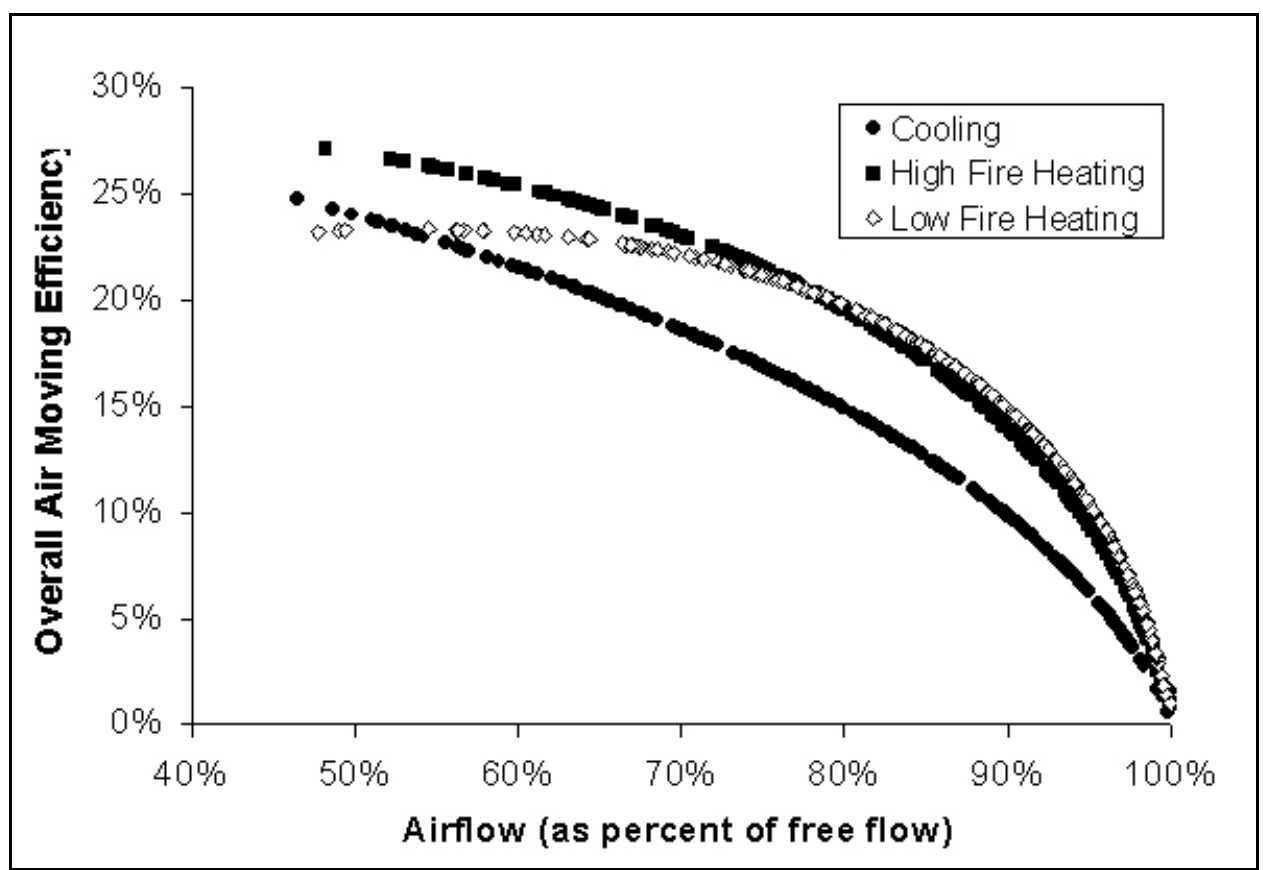

Figure 6.7 Overall Air-Moving Efficiency of Non-Condensing Virtual Furnace Models

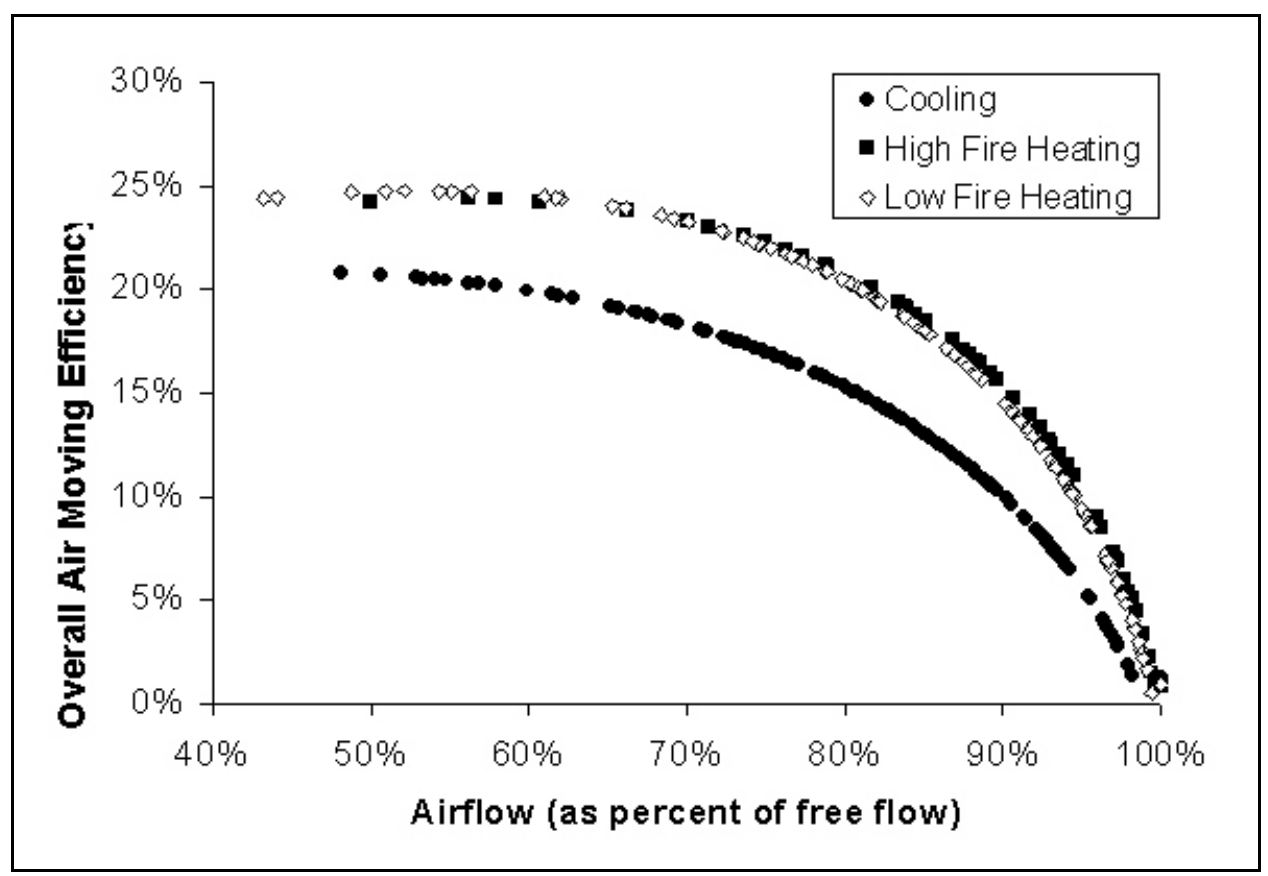

Figure 6.8 Overall Air-Moving Efficiency of Condensing Virtual Furnace Models 


\subsection{Blower Motor Electricity Consumption}

The circulating-air blower motor electricity consumption in steady-state at full-load steady-state is a function of airflow $(Q)$, external static pressure $(P)$, and the overall air-moving efficiency of the furnace $\left(\eta_{\text {overall }}\right)$.

For a baseline furnace, we calculated the circulating-air fan motor electricity consumption for the forward-curved impeller with a direct-drive PSC motor as the air power divided by the overall air-moving efficiency of the blower and blower motor:

$$
B E=\frac{A P}{\text { noverall }}
$$

where;

$\begin{array}{lll}B E & = & \text { blower motor electricity consumption }(\mathrm{W}) \\ A P & = & \text { air power }(\mathrm{W}) ; \text { and } \\ \eta \text { averall } & = & \text { overall air moving efficiency. }\end{array}$

\section{ANNUAL HEATING AND COOLING LOADS IN SAMPLE HOUSES}

\subsection{Annual House Heating Load}

The annual house heating load (HHL) is the total amount of heat output from the furnace that the house needs for an entire year. This includes heat from the burner and heat from the blower and the blower motor.

Burning operating hours $(\mathrm{BOH})$, the number of hours the furnace burner is on during a year, is a key variable in the calculation of HHL. We calculated $\mathrm{BOH}$ for the existing furnace as:

$$
\mathrm{BOH}=\frac{Q_{\mathrm{yr}}}{Q_{\text {in }}}
$$

\begin{tabular}{|c|c|c|}
\hline$B O H$ & $=$ & burner operating hours (hrs/yr); \\
\hline$Q_{y r}$ & $=$ & annual fuel consumption for heating the house- from \\
\hline$O$ & $=$ & $\begin{array}{l}\text { RECS97 (kBtu/yr); and } \\
\text { input capacity of the existing furnace }(\mathrm{kBtu} / \mathrm{hr}) \text {. }\end{array}$ \\
\hline
\end{tabular}

where;

We determined HHL for each sampled household, based on the $\mathrm{BOH}$ and the characteristics of the assigned existing furnace, using the following calculation: 


$$
H H L=[Q i n \times A F U E e x+3.412 \times y \times B E] \times B O H
$$

where;

$$
\begin{array}{lll}
Q_{i n} & = & \text { input capacity of existing furnace }(\mathrm{kBTU} / \mathrm{hr}) ; \\
A F U E_{e x} & = & \text { AFUE of existing furnace; } \\
3.412 & = & \text { constant to convert } \mathrm{kW} \text { to } \mathrm{kBTU} / \mathrm{hr} ; \\
y & = & \text { ratio of blower on-time to burner on-time (from DOE test } \\
B E & = & \text { procedure); and }
\end{array}
$$

The power consumption of the blower motor depends on the steady-state operating conditions (the pressure and airflow) for the furnace. This calculation is explained in Section 6, Calculating Furnace Blower Electricity Consumption.

\subsection{Annual House Cooling Load}

The annual house-cooling load (HCL) is the total amount of cooling provided to the house for the entire cooling season. It includes the cooling provided by the existing air conditioner, and accounts for the waste heat from the inefficiencies of the blower and blower motor. We calculated HCL from the cooling energy consumption reported in RECS97 and the SEER of the assigned existing air conditioners:

$$
H C L=Q_{\text {cool }} \times S E E R e x
$$

where:

$$
\begin{array}{lll}
H C L & = & \text { annual house-cooling load }(\mathrm{kBtu} / \mathrm{h} / \mathrm{yr}) ; \\
Q_{\text {cool }} & = & \text { annual house-cooling electricity consumption, from RECS97 } \\
& & \mathrm{kWh} / \mathrm{yr}) ; \text { and } \\
S E E R_{e x} & = & \text { SEER of the existing air conditioner }(\mathrm{kBtu} / \mathrm{h} / \mathrm{kW}) .
\end{array}
$$

\section{FURNACE ENERGY CONSUMPTION IN SAMPLE HOUSES}

Once the heating and cooling loads of each sample house are known, it is possible to estimate what the energy consumption of alternative (more efficient) furnaces would be if the more-efficient furnaces, rather than the existing equipment, were used in each house.

We calculated the energy consumption for furnaces and boilers incorporating a variety of design options that increase efficiency. The design options shown in Table 8.1 were those that 
met the screening criteria used by DOE in its standards rulemaking. Some options were considered for one or more product classes but not for others (e.g., condensing operation). Lekov et al. provide a discussion of the design options. ${ }^{14}$

Table 8.1 Design Options Considered by Product Class

\begin{tabular}{|c|c|c|c|c|c|c|}
\hline \multirow{3}{*}{ Design Option } & \multicolumn{2}{|c|}{ Gas Furnaces } & \multirow{3}{*}{$\begin{array}{l}\text { Oil-fired } \\
\text { Furnace }\end{array}$} & \multirow{3}{*}{$\begin{array}{c}\text { Manuf- } \\
\text { Home } \\
\text { Gas furn }\end{array}$} & \multirow{2}{*}{\multicolumn{2}{|c|}{$\begin{array}{c}\text { Hot } \\
\text { Water } \\
\text { Boilers } \\
\end{array}$}} \\
\hline & \multirow[t]{2}{*}{\begin{tabular}{|c|} 
Non- \\
weatherized \\
\end{tabular}} & \multirow[t]{2}{*}{ Weatherized } & & & & \\
\hline & & & & & Gas & Oil \\
\hline Improved Heat Exchanger & Y & Y & Y & Y & $\mathrm{Y}$ & $\mathrm{Y}$ \\
\hline Modulating Operation* & $\mathrm{Y}$ & $\mathrm{Y}$ & Y & $\mathrm{Y}$ & $\mathrm{Y}$ & $\mathrm{Y}$ \\
\hline Improved or Increased Insulation & $\mathrm{n} / \mathrm{a}$ & Y & $\mathrm{n} / \mathrm{a}$ & $\mathrm{n} / \mathrm{a}$ & $\mathrm{n} / \mathrm{a}$ & $\mathrm{n} / \mathrm{a}$ \\
\hline $\begin{array}{l}\text { Condensing Secondary Heat } \\
\text { Exchanger }\end{array}$ & Y & $\mathrm{N}$ & $\mathrm{N}$ & $\mathrm{Y}$ & $\mathrm{Y}$ & $\mathrm{Y}$ \\
\hline Electronic Ignition & $\mathrm{b}$ & $\mathrm{b}$ & $\mathrm{b}$ & Y & Y & $\mathrm{b}$ \\
\hline Induced or Forced Draft & $\mathrm{b}$ & $\mathrm{b}$ & $\mathrm{b}$ & Y & Y & $\mathrm{b}$ \\
\hline $\begin{array}{l}\text { Air-Atomized Burner with } \\
\text { Modulation }\end{array}$ & $\mathrm{n} / \mathrm{a}$ & $\mathrm{n} / \mathrm{a}$ & $\mathrm{Y}$ & $\mathrm{n} / \mathrm{a}$ & $\mathrm{n} / \mathrm{a}$ & $\mathrm{Y}$ \\
\hline Increased Motor Efficiency & Y & Y & $\mathrm{Y}$ & Y & Y & $\mathrm{Y}$ \\
\hline Increased Blower Impeller Efficiency & Y & $\mathrm{Y}$ & $\mathrm{Y}$ & Y & $\mathrm{n} / \mathrm{a}$ & $\mathrm{n} / \mathrm{a}$ \\
\hline
\end{tabular}

$\mathrm{Y}=\quad$ The design option was considered for this product class.

$\mathrm{N}=\quad$ The design option was not considered for this product class.

$\mathrm{b}=\quad$ The design option is already in the baseline model of this product class.

$\mathrm{n} / \mathrm{a}=\quad$ The design option is not applicable to this product class.

* Two-stage or step modulation

\subsection{Blower Motor Electricity Design Options}

The electricity consumption of the circulating air blower motor (BE) affects both fuel and electricity consumption. Improving the efficiency of the circulating-air blower in a gas furnace will reduce electricity consumption, and therefore, slightly reduce the amount of heat contributed to the airflow. To make up for the decrease of heat from the motor, there will be a slight increase of gas consumption. Section 6.4, Blower Motor Electricity Consumption, described the calculation of BE for virtual models.

The baseline design for the circulating-air blower is a centrifugal blower with forwardcurved blades powered by a PSC induction motor. The LCC analysis considered three design options to improve blower efficiency: 1) an improved PSC motor (PSC+); 2) an electronicallycommutated motor (ECM); and 3) a backward-curved blower impeller with a different ECM 
motor $(\mathrm{BC} / \mathrm{ECM}+)$.

The PSC + is a motor with a dedicated lamination design using higher-grade electrical steel and tighter windings, with proportionately more copper to limit winding losses. ECM motors have permanent magnets on the rotor. By changing the frequency and voltage on the stator coils, the speed and torque of the motor can be adjusted. The BC/ECM+ motor operates at a higher speed, has a smaller diameter, and has improved magnets and electronics. Furnaces with $\mathrm{ECM}$ and $\mathrm{BC} / \mathrm{ECM}+$ blower motors are programmed to take advantage of the adjustable speed and torque of ECM motors to provide constant airflow, regardless of the static pressure. This is the equivalent of a vertical fan curve at the nominal airflow of the furnace.

Calculation of BE varies with each electricity design option.

For the PSC+ design option,

$$
B E=\frac{A P}{\text { noverall } \times \text { scalar }}
$$

where:

$$
\begin{array}{lll}
A P & = & \begin{array}{l}
\text { air power }(\mathrm{W}), \\
\text { overall efficiency, and }
\end{array} \\
\text { Toverall } & = & \begin{array}{l}
\text { the incremental motor efficiency gain from the PSC }+ \text { design } \\
\text { option. }
\end{array}
\end{array}
$$

AP and $\eta_{\text {overall }}$ depend on static pressure and airflow, as described in section 6.3 on Overall Air-Moving Efficiency.

For the ECM design option, we developed a series of equations to calculate the blower speed and shaft power from the furnace static pressure and airflow, the blower-motor efficiency from the shaft power and speed, and the blower-motor power consumption from the efficiency and shaft power. We developed these equations for ECM motors from product literature of a motor manufacturer. ${ }^{15}$ See Appendix G, Power Consumption of ECM Blower Motors.

For the $\mathrm{BC} / \mathrm{ECM}+$ design option, we developed an equation for $\mathrm{BE}$ as a function of static pressure and airflow from a prototype backward-inclined blower developed by General Electric. ${ }^{16}$ The static pressure and airflow is determined from the intersection of the duct system curve and the vertical fan curve of a furnace, as with an ECM motor. This is explained further in Appendix $\mathrm{H}$, Power Consumption of BC/ECM+ Blower Motors. 


\subsection{Fuel Consumption}

For each design option, the BOH is different, since the AFUE, and blower-motor electricity consumption are different. Therefore, each design option and efficiency level requires a different operating time to heat the same house. We calculated $\mathrm{BOH}$ as:

$$
B O H=\frac{H H L}{Q i n \times A F U E+3.412 \times y \times B E}
$$

where:

$\begin{array}{lll}Q_{i n} & = & \text { input capacity of existing furnace }(\mathrm{kBTU} / \mathrm{h}) ; \\ \text { AFUE } & = & \text { AFUE of design option or efficiency level being considered; } \\ 3.412 & = & \text { a constant to convert } \mathrm{kW} \text { to } \mathrm{kBTU} / \mathrm{h} ; \\ y & = & \text { the ratio of blower on-time to burner on-time; and } \\ B E & = & \text { the power consumption of the blower motor }(\mathrm{kW}) .\end{array}$

$\mathrm{BE}$ varies with airflow and static pressure, which are determined by the intersection of the furnace fan curve and the duct system curve.

We calculated the furnace fuel consumption for each design option and efficiency level using the following formula:

$$
\text { Fuel_Use }=\text { BOHxQin }
$$

where:

$$
\begin{array}{lll}
B O F & = & \text { burner operating hours }(\mathrm{h}) \\
Q_{i n} & = & \text { input capacity of existing furnace }(\mathrm{kBTU} / \mathrm{h}) .
\end{array}
$$

\subsection{Electricity Consumption}

We calculated furnace electricity consumption for the blower, the draft inducer, and the igniter. ${ }^{a}$ The blower moves heated air through the house whenever the furnace is on. It also operates in the cooling season (summer) if the house is air-conditioned. Since the efficiency of the blower will have different impacts on the overall energy consumption of the furnace in different seasons, the electricity use calculation must be carried out separately for winter and summer. We calculated the winter electricity consumption as:

\footnotetext{
a The DOE and ASHRAE test procedures do not count the electricity used by controls when the furnace is not firing.
} 


$$
\text { ElecWinUse }=B O H \times\left(y \times B E+y_{p} \times P E+y_{i g} \times P E_{i g}\right)
$$

where:

$\begin{array}{lll}B O H & = & \text { burner operating hours }(\mathrm{h}) ; \\ y & = & \text { ratio of blower on-time to burner on-time; } \\ B E & = & \text { power consumption of the blower motor }(\mathrm{kW}) ; \\ y_{P} & = & \text { ratio of induced-draft blower on-time to burner on-time; } \\ P E & = & \text { power consumption of the draft-inducer blower-motor }(\mathrm{kW}) ; \\ y_{I G} & = & \text { ratio of ignitor on-time to burner on-time; and } \\ P E_{I G} & = & \text { power consumption of the ignitor }(\mathrm{kW}) .\end{array}$

The ratio of blower on-time to burner on-time and the ratio of induced draft blower ontime to burner on-time are from the ASHRAE test procedure ${ }^{17}$ using delay times for the virtual model furnaces. The ratio of ignitor on-time to burner on-time comes from the DOE test procedure $^{18}$ and the ignition time of the virtual model furnaces. ${ }^{a}$

The details for calculating energy consumption of modulating furnaces appear in Appendix I, Electricity and Gas Use for Modulating Furnaces.

The summer furnace electricity consumption is only the electricity use by the circulatingair blower fan that moves the air cooled by the air conditioner. During cooling mode, the blower motor will operate at a higher speed, so the airflow and static pressure conditions will be different from the heating mode. We calculated summer electricity use as:

$$
\text { ElecSimUse }=\text { ACOHexisting } \times B E c o o l
$$

where:

$$
\begin{array}{ll}
A C O \text { Hexisting } & =\text { air-conditioner operating hours }(\mathrm{h} / \mathrm{yr}) ; \text { and } \\
B E_{\text {cool }} & =\text { power consumption of the blower-motor in cooling mode }(\mathrm{kW}) .
\end{array}
$$

A more efficient blower and blower-motor will reduce the air conditioning hours, since not as much heat from the blower and blower motor will be added to the cooled airstream. However, the annual household cooling load does not change. The cooling provided by the airconditioning system must remain the same, so the air-conditioner operating hours are reduced. See Appendix J, Air Conditioner Operating Hours, for the derivation of these calculations. We

\footnotetext{
a The ASHRAE test procedure does not deal with ignitor energy consumption.
} 
calculated the new air-conditioner operating hours as:

$$
A C_{-} O H_{n e w}=\frac{A C_{-} O H_{\text {exiting }}}{1+\left(\frac{\dot{Q}_{\text {heating_ensting }}-\dot{Q}_{\text {heating new }}}{A C_{\text {capacity }}}\right)}
$$

where:

$$
\begin{aligned}
& \dot{Q}_{\text {heating }}=\quad \text { rate at which the blower and blower motor add heat to the air } \\
& \text { stream (Btu/h); and } \\
& A C_{\text {capacity }}=\text { cooling capacity of the air conditioner }(\mathrm{Btu} / \mathrm{h}) \text {. }
\end{aligned}
$$

\section{BOILER ENERGY CONSUMPTION}

To assign the input capacity for the energy consumption calculation for hot-water boilers, we used the input capacities of the virtual model furnaces for boilers, weighted according to the shipment data from GAMA. ${ }^{3}$ We calculated the heating load for the house and the energy consumption of different model designs in a similar manner as for furnaces. The power consumption of the circulating pump motor is fixed at 62 watts for the baseline model design. ${ }^{19}$ The improved circulating pump uses 42 watts.

We calculated the winter fuel consumption for each design option for boilers using the same approach as for furnaces.

\section{ENERGY CONSUMPTION RESULTS}

The tables in this section present average annual gas or oil consumption, winter electricity consumption, and summer electricity consumption (where relevant) for selected design options in each product class. Lekov et al. provide a discussion of the design options. ${ }^{14}$

As explained in Lutz et al., ${ }^{2}$ the average consumption in each product class considers those sample households that use that type of heating equipment. Thus, the values reflect house characteristics and climate zone as well as equipment efficiency.

Table 10.1 shows the average consumption in each product class for the most common type of equipment. The average fuel use is higher for oil-fired than for gas-fired equipment because the former are used in houses in colder climates. The high winter electricity use of oilfired furnaces reflects the greater fan utilization over a long heating season. The relatively low fuel use of weatherized gas furnaces and manufactured home furnaces reflects their location in warm climates, whereas the high summer electricity use of weatherized gas furnaces reflects greater fan utilization during the cooling season. 
Table 10.1 Annual Energy Consumption of Typical Heating Equipment in Each Product Class

\begin{tabular}{|l|c|c|c|}
\hline \multicolumn{1}{|c|}{ Product Class (AFUE) } & $\begin{array}{c}\text { Average Annual } \\
\text { Gas or Oil Use } \\
\text { (MMBtu) }\end{array}$ & $\begin{array}{c}\text { Average } \\
\text { Winter } \\
\text { Electricity } \\
\text { Use (kWh) }\end{array}$ & $\begin{array}{c}\text { Average Summer } \\
\text { Electricity Use } \\
\text { (kWh) }\end{array}$ \\
\hline Non-weatherized gas furnaces (80\%) & 64.8 & 476 & 157 \\
\hline Weatherized gas furnaces (80\%) & 39.3 & 291 & 372 \\
\hline Manufactured-home furnaces (80\%) & 45.0 & 405 & 229 \\
\hline Oil-fired furnaces (81\%) & 84.7 & 759 & 71 \\
\cline { 1 - 1 } Hot water gas boilers (82\%) & 87.7 & 375 & n.a. \\
\cline { 1 - 1 } Hot water oil-fired boilers $(84 \%)$ & 103.6 & 363 & n.a.
\end{tabular}


Table 10.2 Annual Energy Consumption of Non-Weatherized Gas Furnaces by Design Option

\begin{tabular}{|c|c|c|c|}
\hline $\begin{array}{c}\text { Design Option } \\
\text { (AFUE and technology description) }\end{array}$ & $\begin{array}{l}\text { Average Annual Gas } \\
\text { Use (MMBtu) }\end{array}$ & $\begin{array}{l}\text { Average Winter } \\
\text { Electricity Use } \\
\text { (kWh) }\end{array}$ & $\begin{array}{l}\text { Average Summer } \\
\text { Electricity Use } \\
(\text { kWh })\end{array}$ \\
\hline $78 \%$ Baseline & 66.4 & 488 & 157 \\
\hline $80 \%$ & 64.8 & 476 & 157 \\
\hline $80 \% \mathrm{PSC}+$ & 64.8 & 459 & 149 \\
\hline $80 \% \mathrm{ECM}$ & 65.5 & 399 & 118 \\
\hline $80 \% \mathrm{BC} / \mathrm{ECM}+$ & 66.8 & 240 & 77 \\
\hline $80 \%$ 2-stage Modulation. & 63.4 & 475 & 157 \\
\hline $80 \%$ 2-stage Modulation. ECM & 64.8 & 246 & 118 \\
\hline $80 \%$ 2-stage Modulation. $\mathrm{BC} / \mathrm{ECM}+$ & 65.3 & 201 & 77 \\
\hline $81 \%$ & 64.1 & 470 & 154 \\
\hline $81 \% \mathrm{PSC}+$ & 64.1 & 454 & 149 \\
\hline $81 \% \mathrm{ECM}$ & 64.7 & 296 & 118 \\
\hline $81 \% \mathrm{BC} / \mathrm{ECM}+$ & 65.0 & 237 & 77 \\
\hline $81 \% 2$-stage Modulation & 62.7 & 470 & 157 \\
\hline $81 \%$ 2-stage Modulation ECM & 64.0 & 243 & 118 \\
\hline $81 \%$ 2-stage Modulation BC/ECM+ & 64.5 & 198 & 77 \\
\hline $82 \%$ & 63.2 & 465 & 157 \\
\hline $82 \% \mathrm{PSC}+$ & 63.3 & 448 & 149 \\
\hline $82 \% \mathrm{ECM}$ & 63.9 & 293 & 118 \\
\hline $82 \% \mathrm{BC} / \mathrm{ECM}+$ & 64.2 & 234 & 77 \\
\hline $82 \% 2$-stage Modulation & 62.0 & 464 & 157 \\
\hline $82 \% 2$-stage Modulation ECM & 63.3 & 240 & 118 \\
\hline $82 \%$ 2-stage Modulation $\mathrm{BC} / \mathrm{ECM}+$ & 63.7 & 196 & 77 \\
\hline $83 \%$ & 62.5 & 459 & 157 \\
\hline $90 \%$ Condensing & 57.8 & 421 & 157 \\
\hline $90 \% \mathrm{PSC}+$ & 57.9 & 407 & 149 \\
\hline $90 \% \mathrm{ECM}$ & 58.3 & 278 & 118 \\
\hline $90 \% \mathrm{BC} / \mathrm{ECM}+$ & 58.5 & 224 & 77 \\
\hline 91\% 2-stage Modulation ECM & 57.2 & 239 & 118 \\
\hline $91 \%$ 2-stage Modulation $\mathrm{BC} / \mathrm{ECM}+$ & 57.5 & 197 & 77 \\
\hline
\end{tabular}




\begin{tabular}{|l|c|c|c|}
\hline \multicolumn{1}{|c|}{$\begin{array}{c}\text { Design Option } \\
\text { (AFUE and technology description) }\end{array}$} & $\begin{array}{c}\text { Average Annual Gas } \\
\text { Use (MM Btu) }\end{array}$ & $\begin{array}{l}\text { Average Winter } \\
\text { Electricity Use } \\
\text { (kWh) }\end{array}$ & $\begin{array}{c}\text { Average Summer } \\
\text { Electricity Use } \\
\text { (kWh) }\end{array}$ \\
\hline $91 \%$ Step Modulation ECM & 56.8 & 237 & 118 \\
$91 \%$ Step Modulation BC/ECM+ & 57.3 & 196 & 77 \\
\hline $92 \%$ Increased HX Area & 56.6 & 412 & 157 \\
$92 \%$ PSC+ & 56.6 & 398 & 149 \\
$92 \%$ ECM & 57.1 & 272 & 118 \\
$92 \%$ BC/ECM+ & 57.3 & 234 & 77 \\
\hline $93 \%$ 2-stage Modulation ECM & 56.0 & 193 & 118 \\
$93 \%$ 2-stage Modulation BC/ECM+ & 56.3 & 232 & 77 \\
$93 \%$ Step Modulation ECM & 55.6 & 192 & 77 \\
\hline $93 \%$ Step Modulation BC/ECM+ & 56.1 & 225 & 118 \\
\hline $96 \%$ Step Modulation ECM & 53.9 & 186 & 77 \\
\hline $96 \%$ Step Modulation BC/ECM+ & 54.3 & \\
\hline
\end{tabular}


Table 10.3 Annual Energy Consumption of Weatherized Furnaces by Design Option

\begin{tabular}{|c|c|c|c|}
\hline $\begin{array}{c}\text { Design Option } \\
\text { (AFUE and technology description) }\end{array}$ & $\begin{array}{l}\text { Average Annual Gas } \\
\text { Use (MMBtu) }\end{array}$ & $\begin{array}{c}\text { Average Winter } \\
\text { Electricity Use } \\
(\mathbf{k W h})\end{array}$ & $\begin{array}{c}\text { Average Summer } \\
\text { Electricity Use } \\
(\mathbf{k W h})\end{array}$ \\
\hline $78 \%$ Baseline & 40.3 & 298 & 372 \\
\hline $80 \%$ Increased HX Area & 39.3 & 291 & 372 \\
\hline $80 \%$ Improved Insulation & 39.1 & 290 & 372 \\
\hline $80 \% \mathrm{PSC}+$ & 39.3 & 281 & 354 \\
\hline $80 \% \mathrm{ECM}$ & 39.7 & 182 & 281 \\
\hline $80 \%$ Improved Heat Transfer & 39.3 & 291 & 372 \\
\hline $81 \%$ Increased HX Area & 38.8 & 288 & 372 \\
\hline $81 \%$ Improved Insulation & 38.7 & 286 & 372 \\
\hline $81 \% \mathrm{PSC}+$ & 38.9 & 277 & 354 \\
\hline $81 \% \mathrm{ECM}$ & 39.3 & 180 & 281 \\
\hline $81 \%$ Improved Heat Transfer & 38.8 & 288 & 372 \\
\hline $82 \%$ Increased HX Area & 38.3 & 284 & 372 \\
\hline $82 \%$ Improved Insulation & 38.2 & 283 & 372 \\
\hline $82 \% \mathrm{PSC}+$ & 38.4 & 274 & 354 \\
\hline $82 \% \mathrm{ECM}$ & 38.8 & 178 & 281 \\
\hline $82 \%$ Improved Heat Transfer & 38.3 & 284 & 372 \\
\hline $83 \%$ Increased HX Area & 37.9 & 281 & 372 \\
\hline $83 \%$ Improved Insulation & 37.8 & 280 & 372 \\
\hline $83 \% \mathrm{PSC}+$ & 37.9 & 271 & 354 \\
\hline $83 \% \mathrm{ECM}$ & 38.3 & 176 & 281 \\
\hline $83 \%$ Improved Heat Transfer & 37.9 & 281 & 372 \\
\hline
\end{tabular}


Table 10.4 Annual Energy Consumption of Manufactured-Home Gas Furnaces by Design Option

\begin{tabular}{|l|c|c|c|}
\hline \multicolumn{1}{|c|}{$\begin{array}{c}\text { Design Option } \\
\text { (AFUE and technology description) }\end{array}$} & $\begin{array}{c}\text { Average Annual } \\
\text { Gas Use (MM Btu) }\end{array}$ & $\begin{array}{c}\text { Average Winter } \\
\text { Electricity Use } \\
\text { (kWh) }\end{array}$ & $\begin{array}{c}\text { Average Summer } \\
\text { Electricity Use } \\
\text { (kWh) }\end{array}$ \\
\hline $75 \%$ Baseline & 50.8 & 374 & 229 \\
\hline $80 \%$ & 45.0 & 405 & 229 \\
$80 \%$ ECM & 45.8 & 221 & 229 \\
$80 \%$-stage Modulation & 43.9 & 398 & 229 \\
\hline $81 \%$ & 44.5 & 400 & 126 \\
$81 \%$ ECM & 45.3 & 218 & 229 \\
\hline $81 \%$ 2-stage Modulation & 43.4 & 393 & 229 \\
\hline $82 \%$ & 44.0 & 395 & 126 \\
\hline $82 \%$ ECM & 44.7 & 389 & 229 \\
\hline $82 \%$ 2-stage Modulation & 42.9 & 359 & 233 \\
\hline $90 \%$ & 40.2 & & 229 \\
\hline
\end{tabular}


Table 10.5 Annual Energy Consumption of Oil Furnaces by Design Option

\begin{tabular}{|c|c|c|c|}
\hline $\begin{array}{c}\text { Design Option } \\
\text { (AFUE and technology description) }\end{array}$ & $\begin{array}{c}\text { Average Annual } \\
\text { Oil Use } \\
\text { (MMBtu) }\end{array}$ & $\begin{array}{c}\text { Average Winter } \\
\text { Electricity Use } \\
(\mathrm{kWh})\end{array}$ & $\begin{array}{c}\text { Average } \\
\text { Summer } \\
\text { Electricity Use } \\
(\mathbf{k W h})\end{array}$ \\
\hline $78 \%$ Baseline & 87.8 & 787 & 71 \\
\hline $80 \%$ & 85.7 & 768 & 71 \\
\hline $81 \%$ Increased HX Area & 84.7 & 759 & 71 \\
\hline $81 \%$ Atomized Burner 2-stage Modulation. & 82.6 & 845 & 71 \\
\hline $81 \%$ Interrupted Ignition & 84.8 & 727 & 71 \\
\hline $81 \%$ ImprovedS upplyF an Motor (ECM) & 85.6 & 534 & 57 \\
\hline $82 \%$ & 83.7 & 750 & 71 \\
\hline $82 \%$ Atomized Burner 2-stage Modulation. & 81.6 & 836 & 71 \\
\hline $82 \%$ Interrupted Ignition & 83.8 & 719 & 71 \\
\hline $82 \%$ ImprovedS upplyF an Motor (ECM) & 84.6 & 527 & 57 \\
\hline $83 \%$ & 82.7 & 741 & 71 \\
\hline $83 \%$ Atomized Burner 2-stage Modulation. & 80.7 & 826 & 71 \\
\hline $83 \%$ Interrupted Ignition & 82.8 & 710 & 71 \\
\hline $83 \%$ ImprovedSupplyF an Motor (ECM) & 83.6 & 521 & 57 \\
\hline $84 \%$ & 81.7 & 733 & 71 \\
\hline $84 \%$ Atomized Burner 2-stage Modulation. & 79.8 & 817 & 71 \\
\hline $84 \%$ Interrupted Ignition & 81.8 & 702 & 71 \\
\hline $84 \%$ ImprovedSupplyF an Motor (ECM) & 82.6 & 515 & 57 \\
\hline $85 \%$ & 80.8 & 724 & 71 \\
\hline $85 \%$ Atomized Burner 2-stage Modulation. & 78.9 & 807 & 71 \\
\hline $85 \%$ Interrupted Ignition & 80.9 & 694 & 71 \\
\hline $85 \%$ ImprovedSupplyF an Motor (ECM) & 81.6 & 509 & 57 \\
\hline
\end{tabular}


Table 10.6 Annual Energy Consumption of Hot Water Gas Boilers by Design Option

\begin{tabular}{|c|c|c|}
\hline $\begin{array}{c}\text { Design Option } \\
\text { (AFUE and technology description) }\end{array}$ & $\begin{array}{c}\text { Average Annual Gas Use } \\
\text { (MMBtu) }\end{array}$ & $\begin{array}{c}\text { Average Winter Electricity Use } \\
(\mathrm{kWh})\end{array}$ \\
\hline $80 \%$ Baseline & 93.5 & 379 \\
\hline $81 \%$ & 88.8 & 380 \\
\hline $81 \%$ 2-stage Modulation + Induced Draft & 87.4 & 562 \\
\hline $81 \%$ Improved Circulation Pump & 89.0 & 338 \\
\hline $82 \%$ & 87.7 & 375 \\
\hline $82 \%$ 2-stage Modulation + Induced Draft & 86.4 & 555 \\
\hline $82 \%$ Improved Circulation Pump & 87.9 & 334 \\
\hline $\begin{array}{l}83 \% \text { Improved Heat Transfer / Elec. } \\
\text { Ignition }\end{array}$ & 86.7 & 371 \\
\hline $83 \%$ 2-stage Modulation + Induced Draft & 85.4 & 549 \\
\hline $83 \%$ Improved Circulation Pump & 86.9 & 330 \\
\hline $84 \%$ & 85.7 & 367 \\
\hline $84 \%$ 2-stage Modulation + Induced Draft & 84.4 & 542 \\
\hline 84\% Improved Circulation Pump & 85.8 & 326 \\
\hline $88 \%$ & 81.8 & 350 \\
\hline $91 \%$ & 79.3 & 301 \\
\hline $99 \%$ & 73.0 & 277 \\
\hline
\end{tabular}


Table 10.7 Annual Energy Consumption of Hot Water Oil Boilers by Design Option

\begin{tabular}{|c|c|c|}
\hline $\begin{array}{c}\text { Design Option } \\
\text { (AFUE and technology description) }\end{array}$ & $\begin{array}{l}\text { Average Annual Oil Use } \\
\text { (MMBtu) }\end{array}$ & $\begin{array}{c}\text { Average Winter } \\
\text { Electricity Use } \\
(\mathrm{kWh})\end{array}$ \\
\hline $80 \%$ Baseline & 108.7 & 381 \\
\hline $81 \%$ & 107.4 & 377 \\
\hline $81 \%$ Atomized Burner 2-stage Modulation & 105.9 & 567 \\
\hline $81 \%$ Interrupted Ignition & 107.5 & 345 \\
\hline $81 \%$ Improved Circulation Pump & 107.5 & 338 \\
\hline $82 \%$ & 106.1 & 372 \\
\hline $82 \%$ Atomized Burner 2-stage Modulation & 104.6 & 560 \\
\hline $82 \%$ Interrupted Ignition & 106.2 & 341 \\
\hline $82 \%$ Improved Circulation Pump & 106.2 & 334 \\
\hline $83 \%$ & 104.8 & 368 \\
\hline $83 \%$ Atomized Burner 2-stage Modulation & 103.4 & 554 \\
\hline $83 \%$ Interrupted Ignition & 104.9 & 337 \\
\hline $83 \%$ Improved Circulation Pump & 105.0 & 330 \\
\hline $84 \%$ & 103.6 & 363 \\
\hline $84 \%$ Atomized Burner 2-stage Modulation. & 102.2 & 548 \\
\hline $84 \%$ Interrupted Ignition & 103.7 & 333 \\
\hline $84 \%$ Improved Circulation Pump & 103.7 & 326 \\
\hline $86 \%$ & 101.2 & 355 \\
\hline $86 \%$ Atomized Burner 2-stage Modulation. & 99.9 & 535 \\
\hline $86 \%$ Interrupted Ignition & 101.3 & 325 \\
\hline $86 \%$ Improved Circulation Pump & 101.3 & 319 \\
\hline $90 \%$ & 97.0 & 276 \\
\hline $95 \%$ & 91.9 & 262 \\
\hline
\end{tabular}

\section{Acknowledgments}

This work was supported by the Office of Building Technologies and Community Systems of the U.S. Department of Energy, under Contract No. DE-AC03-76SF00098. We acknowledge the guidance of the DOE Program manager, Mohammed Khan, and the comments of John Busch of LBNL. Diana Morris and Karen Olson assisted with production. 


\section{REFERENCES}

1. U.S. Department of Energy-Office of Building Technologies, Technical Support Document: Energy Conservation Program for Consumer Products: Energy Conservation Standards for Residential Furnaces and Boilers - ANOPR Version, 2003, U.S. Department of Energy. Washington, DC. Report No. LBNL-53984.

2. Lutz, J., A. Lekov, P. Chan, and S. Meyers, Life-Cycle Cost Analysis of Energy Efficiency Design Options for Residential Furnaces and Boilers, 2003, Lawrence Berkeley National Laboratory. Berkeley, CA. Report No. LBNL-53950.

3. Kendall, M., Appendix A - Furnace Shipments; Appendix B - Boiler. Comment \# 24 submitted to Docket Number: EE-RM/STD-01-350 Shipments, April 10, 2002, GAMA. Arlington, VA.

4. Gas Appliance Manufacturers Association, Consumers' Directory of Certified Efficiency Ratings for Residential Heating and Water Heating Equipment, including First Supplement, April, 2002. Cortland, NY. Prepared by Intertek Testing Services.

5. U.S. Department of Energy - Energy Information Administration, Residential Energy Consumption Survey: Household Energy Consumption and Expenditures 1997, 1999. Washington, DC. Report No. DOE/EIA-0321(97).

$<$ http://www.eia.doe.gov/emeu/recs/recs97/publicusefiles.html>

6. American Society of Heating Refrigeration and Air-Conditioning Engineers, ASHRAE 1997 Handbook - Fundamentals. 1997, Atlanta, GA.p. 3.12.

7. Proctor, J. and D. Parker, Hidden Power Drains: Residential Heating and Cooling Fan Power Demand. In ACEEE 2000 Summer Study on Energy Efficiency in Buildings.2000. Asilomar, CA, August 20-25: American Council for an Energy-Efficient Economy. 1: pp. 225-234.

8. Lennox Industries Inc., Lennox Industries Engineering Data: 90UGF (Elite 90-S Upflow Gas Furnace) Bulletin \#210171., 1997. Lennox Industries Inc.

9. Lennox Industries Inc., Lennox Engineering Data: G26 (Elite 90 Series Upflow Gas Furnace), Bulletin \#210027, 1998. Lennox Industries Inc.

10. Lennox Industries Inc., Lennox Engineering Data: GHR26 (Elite 90 Series Horizontal/Downflow Gas Furnace) Bulletin \# 210093, 1998. Lennox Industries, Inc.

11. Lennox Industries Inc., Lennox Engineering Data: G23 (Elite 80 Upflow Gas Furnace) Bulletin \#210026, 1998. Lennox Industries Inc. 
12. Lennox Industries Inc., Lennox Engineering Data: G40DF (Merit Series Downflow Gas Furnace) Bulletin No. 210320., 2002. Lennox Industries, Inc. (Last accessed July, 2003). $<\mathrm{http}: / /$ www.lennoxcommercial.com/tech_pdf/ehb_g40df_0206.pdf $>$

13. Lennox Industries Inc., Lennox Engineering Data: G40UH (Merit Series Upflow/Horizontal Gas Furnace) Bulletin No. 210320., 2002. Lennox Industries, Inc. (Last accessed July, 2003).

$<$ http://www.lennoxcommercial.com/tech_pdf/ehb_g40uh_0206.pdf $>$

14. Lekov, A., G. Stevens, J. Lutz, and S. Meyers, Cost and Energy Consumption of Energy Efficiency Design Options for Residential Furnaces and Boilers, 2003, Lawrence Berkeley National Laboratory. Berkeley, CA. Report No. LBNL-52762.

15. General Electric Company, General Electric Brochure, 2002. General Electric Company. (Last accessed August 28, 2002).

$<$ http://www.geindustrial.com/products/brochures/GET-8068.pdf $>$

16. Wang, S. and H. Wiegman, Topical Progress Report for the Variable Speed Integrated Intelligent HVAC Blower, November 14, 2001, GE Corporate Research and Development. Niskayuna, NY.

17. American Society for Heating Refrigeration and Air-Conditioning Engineers, Method of Testing for Annual Fuel Ultilization Efficiency of Residential Central Furnaces and Boilers, 1993, ANSI/ASHRAE. Atlanta, GA. Report No. Standard 103-1993.

18. Title 10, Code of Federal Regulations, Part 430- Energy Conservation Program for Consumer Products, Appendix N to Subpart B of Part 430-Uniform Test Method for Measuring the Energy Consumption of Furnaces and Boilers, January 1, 1999. Chapter II.

19. Taco Inc., 110-120 Red Baron Circulators, 2003. 


\section{APPENDIX A: DATABASE OF REDUCED SET OF FURNACE MODELS}

\section{TABLE OF CONTENTS}

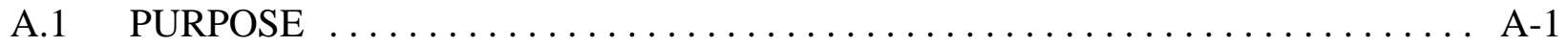

A.2 DATABASE DEVELOPMENT $\ldots \ldots \ldots \ldots \ldots \ldots \ldots \ldots \ldots \ldots \ldots \ldots \ldots$ A-1

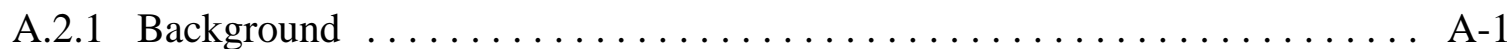

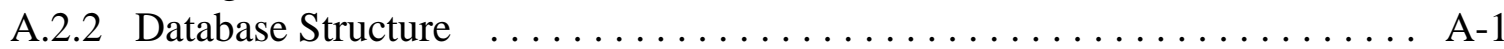

\section{LIST OF TABLES}

Table A.2.1 Furnace Data Table Field Names and Definitions . . . . . . . . . . . . . . A-5

Table A.2.2 Pressure Table Field Names and Definitions . . . . . . . . . . . . . . A-6

Table A.2.3 Power Table Field Names and Definitions $\ldots \ldots \ldots \ldots \ldots \ldots \ldots \ldots$ A-6

Table A.2.4 Series Table Field Names and Definitions $\ldots \ldots \ldots \ldots \ldots \ldots \ldots \ldots$ A-7

\section{LIST OF FIGURES}

Figure A.2.1 Map Showing Relationship Between the Furnace Data Table, Pressure Table, and Power Table ................................ 1-3

Figure A.2.2 Map Showing Relationship Between the Furnace Data Table, Series Table, and Delay Times Table ......................... 1-3

Figure A.2.3 Map Showing Relationship Between the GAMA Directory April 2002 Table Model Translation Table and the Furnace Data Table ............ 1-4

Figure A.2.4 Map Showing Relationship Between the GAMA Directory April 2002 Table Model Translation Table and the Furnace Data Table ........... 1-4 


\section{APPENDIX A: DATABASE OF REDUCED SET OF FURNACE MODELS}

\section{A.1 PURPOSE}

The Reduced Set of Furnace Models Database was developed to create a base for two aspects of the Furnace/Boiler LCC analysis: 1) to identify furnace models which represent units with different design characteristics and 2) expand the GAMA directory data for each furnace model by adding information provided in the manufacturers product literature. One application of the database was to develop generic models for the sizes of residential furnaces which were used in the LCC analysis.

The April 2002 GAMA Directory of Certified Heating Equipment Database ${ }^{1}$ contains more than 19,000 gas furnace models. Many models represent essentially identical units which differ only by a brand name. In the LCC analysis we use generic furnace models which are representative of specific design characteristics. The newly developed database of furnace models (further referred as the reduced set of furnace models or simply the reduced set), represent non-repetitive furnace models only. After examining the April 2002 GAMA directory database we determined that about 2,400 models may be considered sufficiently different to be listed as unique models. This database is the first published attempt to comprehensively list unique furnace models together with available manufacturer's data.

Once the reduced set was identified, we examined the manufacture literature and added additional data related to the airflow results at different static pressure, power data for the blower, blower motor type, blower wheel dimensions, furnace dimensions, low fire heating input and output capacity for modulating furnaces, delay times, etc. For a more detailed discussion of the fields available in the database see the tables below.

\section{A.2 DATABASE DEVELOPMENT}

\section{A.2.1 Background}

In 2002, we began to develop a database of product specifications (such as different design characteristics) for residential furnaces currently sold in the U.S. A preliminary version of the Database was completed at the end of 2002. Subsequent changes were made to include data from the manufacturer literature.

\section{A.2.2 Database Structure}

The Reduced Set of Furnace Models Database was developed using the Microsoft Access relational database application. A relational database provides the user with the means of sorting and extracting information from its tables through the use of queries; queries help isolate and view particular items of interest and can be used to display. In this database, for example, gas furnaces models that are condensing, have two-stage modulation, with a certain input capacity 
range, and that use ECM blower motors can be identified. There are four principal data tables in the database as described below. Furthermore, Figures A.1 and A.2 provide the relationship between them. The tables provide a list the variable names and definitions used in the database tables.

The Furnace Data Table contains furnace information gathered from the GAMA directory database and manufacturer product literature such as input capacity, output capacity, AFUE, blower motor type, and blower dimensions. The manufacturer name, brand names, and series names are also included by linking to the Series Table. The field SeriesID is included in the Furnace Data Table to serve as a linking variable to the Series Table (see Figure A.2). Furthermore, the Model Translation Table provides a link between data Furnace Data Table and the GAMA Directory April 2002 Table (see Figure A.3).

The Pressure Table contains information on Airflow (CFM) at different static pressures (in.w.g.) for different blower motor speeds. The field FurnaceDataID is also included in this table; it is the linking variable between the Furnace Data Table and the Pressure Table (see Figure A.1).

The Power Table contains information on power consumption in watts for the furnace blower motor at different static pressures (in.w.g.) for different blower motor speeds. The P field Pressure_ID is also included in the Power Table; it is the linking variable between the Pressure Table and the Power Table (see Figure A.1).

The Series Table contains furnace information related to a series of furnaces including manufacturer, related brands, warranty information, etc. This table also links to the Delay Times Table, which includes pre-purge, post-purge, on-delay, off-delay and ignitor on-time information. (see Figure A.2). In addition, the References Table provides a link between the Series Table and the Bibliographies Table, which has all the product literature bibliographies (see Figure A.4) 


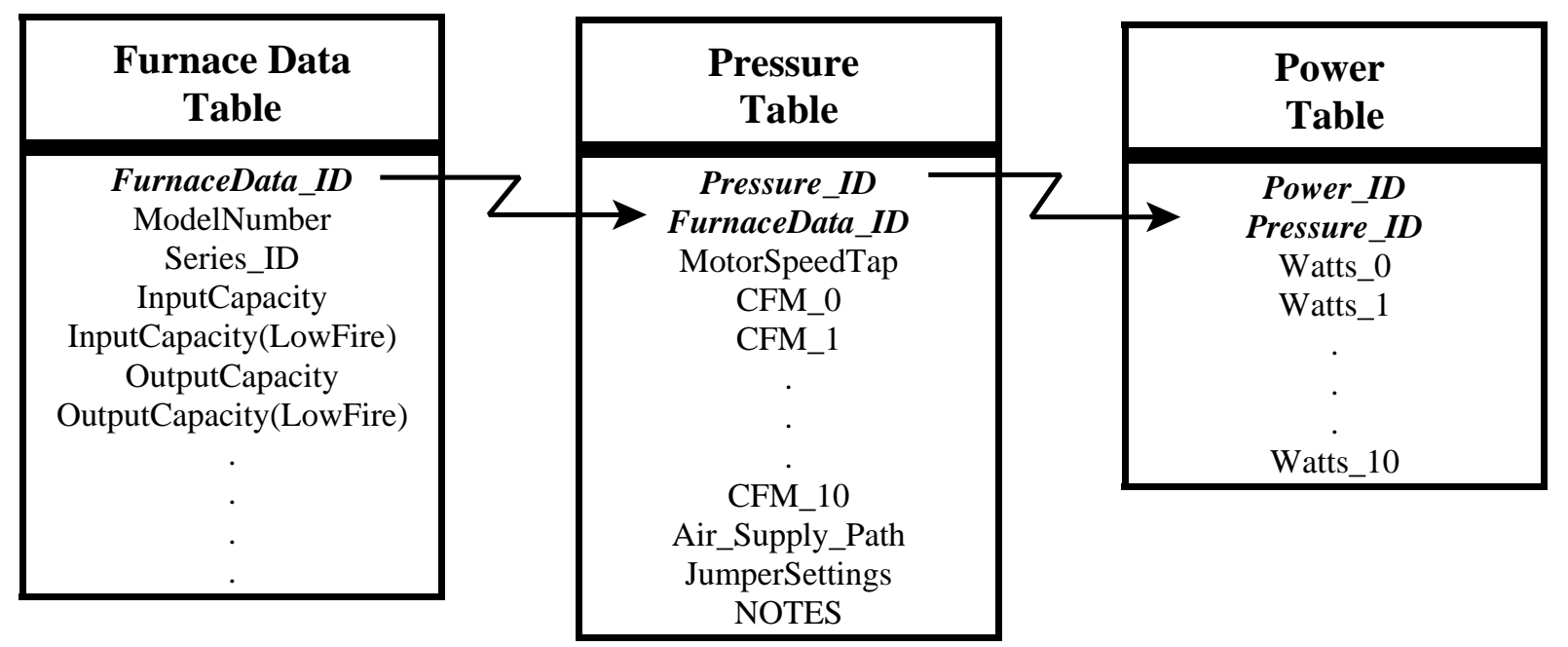

Figure A.1 Map Showing Relationship Between the Furnace Data Table, Pressure Table, and Power Table

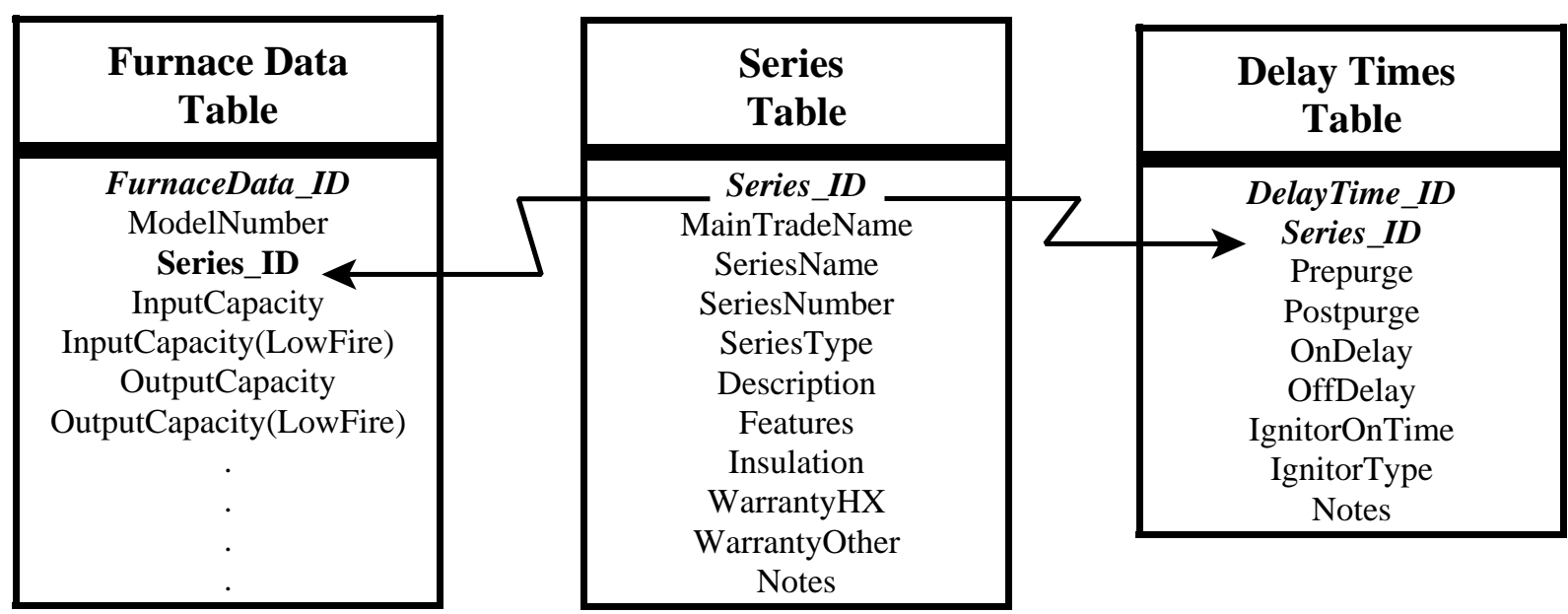

Figure A.2 Map Showing Relationship Between the Furnace Data Table, Series Table, and Delay Times Table 


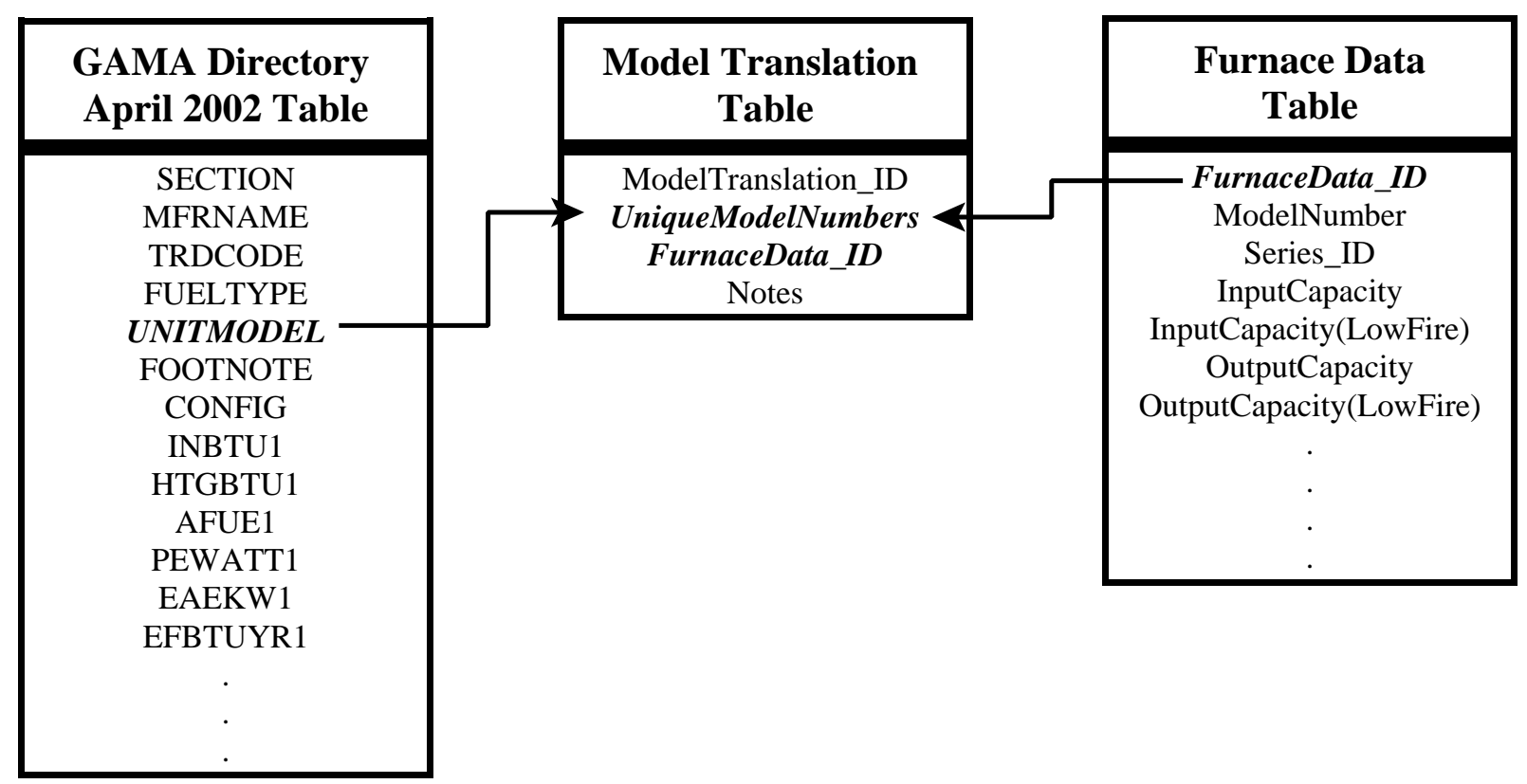

Figure A.3 Map Showing Relationship Between the GAMA Directory April 2002 Table Model Translation Table and the Furnace Data Table

\begin{tabular}{|c|c|c|}
\hline $\begin{array}{c}\text { Series } \\
\text { Table }\end{array}$ & $\begin{array}{c}\text { References } \\
\text { Table }\end{array}$ & $\begin{array}{c}\text { References } \\
\text { Table }\end{array}$ \\
\hline $\begin{array}{c}\text { Series_ID } \\
\text { MainTradeName } \\
\text { SeriesName } \\
\text { SeriesNumber } \\
\text { SeriesType } \\
\text { Description } \\
\text { Features } \\
\text { Insulation } \\
\text { WarrantyHX } \\
\text { WarrantyOther } \\
\text { Notes }\end{array}$ & $\begin{array}{c}\text { Ref_ID } \\
\text { BibliographyID } \\
\text { Series_ID } \\
\text { Notes } \\
\end{array}$ & $\begin{array}{c}\text { _BibliographyID } \\
\text { Series_ID } \\
\text { Title } \\
\text { Author } \\
\text { PublicationNumber } \\
\text { EndNoteCitation } \\
\text { Type } \\
\text { URL } \\
\text { LastAccessDate } \\
\text { LiteratureDate } \\
\text { Notes }\end{array}$ \\
\hline
\end{tabular}

Figure A.4 Map Showing Relationship Between the GAMA Directory April 2002 Table Model Translation Table and the Furnace Data Table 
Table A.2.1 Furnace Data Table Field Names and Definitions

\begin{tabular}{|c|c|}
\hline Field Name & Field Definitions \\
\hline Furnace_ID & Unique identification number for each record \\
\hline ModelNumber & Actual Model Number from GAMA database \\
\hline Series_ID & Connects the individual model with the Series Table \\
\hline InputCapacity & Input Capacity as reported by GAMA database (field name INBTU1) \\
\hline InputCapacity(LowFire) & Input Capacity during low fire for Two-Stage or modulating furnaces \\
\hline OutputCapacity & Output Capacity as reported by GAMA database (field name HTGBTU1) \\
\hline OutputCapacity(LowFire) & Output Capacity during low fire for Two-Stage or modulating furnaces \\
\hline AFUE & Annual Fuel Utilization Efficiency (AFUE) as reported by GAMA database (field name AFUE1) \\
\hline PE & PE value in watts as reported by GAMA database (field name PEWATT1) \\
\hline EAE & Eae value in kilowatts as reported by GAMA database (field name EAEKW1) \\
\hline EF & EF value in BTU/year as reported by GAMA database (field name EFBTUYR1) \\
\hline AC_Tons(Max) & Reported maximum number of Tons of AC delivered by Furnace \\
\hline AC_Tons(Min) & Reported minimum number of Tons of AC delivered by Furnace \\
\hline TempMax(HighFire) & Temperature range maximum value reported during High Fire Heating \\
\hline TempMax(LowFire) & Temperature range maximum value reported during Low Fire Heating (Two-Stage/mod. furnaces) \\
\hline TempMin(HighFire) & Temperature range minimum value reported during High Fire Heating \\
\hline TempMin(LowFire) & Temperature range minimum value reported during Low Fire Heating (Two-Stage/mod. furnaces) \\
\hline BlowerMotorType & Indoor Blower motor type (either PSC, ECM, or Shaded Pole) \\
\hline BlowerMotorDriveType & Indoor Blower motor type (either Direct Drive or Belt Driven) \\
\hline BlowerMotor_HP & Indoor Blower motor horsepower (nominal) \\
\hline BlowerMotorSpeedTaps & Number of speeds of indoor blower $(1,2,3,4,5$ or variable) \\
\hline BlowerWheelSize & Blower Wheel Diameter \& Width [in] \\
\hline BlowerMotorNotes & Indoor Blower notes \\
\hline CoolingBlowerTap & Indoor Blower Tap default factory setting for Cooling \\
\hline HighFireBlowerTap & Indoor Blower Tap default factory setting for High Fire Heating \\
\hline LowFireBlowerTap & Indoor Blower Tap default factory setting for Low Fire Heating (for Two-Stage or mod. furnaces) \\
\hline NoAirFilter & CFM Tested without filter (YES/NO field) \\
\hline AirflowNotes & Notes regarding AirFlow data \\
\hline InducerType & Draft inducer blower type \\
\hline InducerSize & Draft inducer blower size \\
\hline InducerMotorType & Draft inducer blower motor type \\
\hline InducerMotorSize & Draft inducer blower motor size \\
\hline InducerMotorSpeedTaps & Draft inducer blower motor speed taps $(1,2,3,4,5$ or variable $)$ \\
\hline InducerNotes & Draft inducer blower notes \\
\hline SupplyAir_OutletDepth & Supply Air Outlet dimensions (depth) [in] \\
\hline SupplyAir_OutletWidth & Supply Air Outlet dimensions (width) [in] \\
\hline HeatExchanger(Primary) & Heat Exchanger Type (Tubular, Clam Shell, Serpentine) \\
\hline HeatExchanger(Secondary) & Second Heat Exchanger Type (Tubular, Clam Shell, Serpentine) for condensing furnaces \\
\hline HeatExchangerNotes & Notes for Heat Exchanger \\
\hline Burners & Number of Burners \\
\hline FurnaceHeight & Height of Furnace \\
\hline FurnaceWidth & Width of Furnace \\
\hline FurnaceDepth & Depth of Furnace \\
\hline FurnaceWeight & Weight of Furnace \\
\hline
\end{tabular}




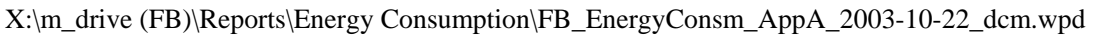

printed June 21, 2004

\begin{tabular}{|c|c|}
\hline Configuration & Configuration of Furnace (Upflow, Downflow, Horizontal) \\
\hline NOx_Model & Whether Model meets California Air Quality Management District NOx emissions requirements \\
\hline FuelType & $\mathrm{G}=\mathrm{Gas}, \mathrm{L}=$ Propane $. \mathrm{O}=$ Oil (from GAMA database) \\
\hline FurnaceType & Either Weatherized $(\mathrm{W})$ or Non-Weatherized $(\mathrm{N})$ from GAMA database \\
\hline 1_Electroniclgnition & GAMA standard footnote 1: Electronic Ignition \\
\hline 2_Electro_MechVent & GAMA standard footnote 2: Electro-Mechanical Vent Damper(s) specified by the Furnace Mfr. \\
\hline 3_PowerVent & GAMA standard footnote 3: Power Combustion or Power Vent \\
\hline 4_Condensing & GAMA standard footnote 4: Condensing Type \\
\hline 5_DirectVent & GAMA standard footnote 5: Direct Vent (Includes Venting and Combustion Air Systems). \\
\hline 6_Packaged & GAMA standard footnote 6: Single Package unit (Combination Heating/Cooling). \\
\hline Modulation & Type of modulation: (Single Stage, Two-Stage, Continuous Modulating) \\
\hline VentingFootnotes & GAMA non-standard footnote: May be installed as Direct Vent, Non-direct vent, etc... \\
\hline ManufacturedHome & $\begin{array}{l}\text { GAMA non-standard footnote: Manufactured Housing Only or Manufactured (mobile) home approved } \\
\text { with accessory kit. }\end{array}$ \\
\hline BlowerMotorFootnotes & GAMA non-standard footnote: Variable Speed Motor \\
\hline HighAltitudeDerated & If model was input was derated for high altitude (YES/NO) \\
\hline SEER & SEER value \\
\hline DateAdded & Date Added to GAMA Directory (Default Date is set to Apr-02) \\
\hline DateDiscontinued & Date marked discontinued or deleted from GAMA Directory (Earliest date is Apr-02) \\
\hline Notes & otes related to individual model \\
\hline
\end{tabular}

\section{Table A.2.2 Pressure Table Field Names and Definitions}

\begin{tabular}{|l|l|}
\hline \multicolumn{1}{|c|}{ Field Name } & \multicolumn{1}{c|}{ Field Definitions } \\
\hline Pressure_ID & Unique identification number for each record \\
FurnaceData_ID & Connects to the Furnace Data Table \\
MotorSpeedTap & Name of the Series \\
CFM_0 to CFM_10 & 10 Field Names CFM_\# which represent Airflow @ 0.0 in w.g. through 1.0 in w.g. (CFM) \\
Air_Supply_Path & Configuration of the return air supply, e.g. single-side, two-sides, bottom, etc \\
JumperSettings & Jumper Settings \\
Notes & Notes
\end{tabular}

\section{Table A.2.3 Power Table Field Names and Definitions}

\begin{tabular}{|l|l|}
\hline \multicolumn{1}{|c|}{ Field Name } & \multicolumn{1}{c|}{ Field Definitions } \\
\hline Power_ID & Unique identification number for each record \\
Pressure_ID & Connects to the Pressure Table \\
Watts_0 to Watts_10 & 10 Field Names Watts_\# which represent Watts @ 0.0 in w.g. through 1.0 in w.g. (CFM) \\
Notes & Notes
\end{tabular}




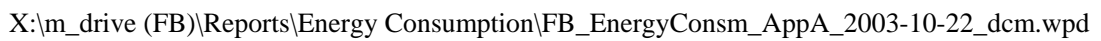

Table A.2.4 Series Table Field Names and Definitions

\begin{tabular}{|l|l|}
\hline \multicolumn{1}{|c|}{ Field Name } & \multicolumn{1}{c|}{ Field Definitions } \\
\hline Series_ID & Unique identification number for each record \\
MainTradeName & $\begin{array}{l}\text { Main Trade Name Associated with Series. For other tradenames associated to some series go to the } \\
\text { SeriesTradeNames table. } \\
\text { Name of the Series }\end{array}$ \\
Series Name & Number of the Series \\
Series Number & Product Category (Baseline, Deluxe, Premium) \\
Series Type & Description of the series from manufacturer literature \\
Description & Features \\
Features & Insulation used \\
Insulation & Warranty Information for the Heat Exchanger \\
WarrantyHX & Warranty Information for other furnace parts \\
WarrantyOther & Notes \\
Notes &
\end{tabular}




\section{REFERENCES}

1. Gas Appliance Manufacturers Association, GAMA Directory Database, April 2002. Gas Appliance Manufacturers Association. <http://www.gamanet.org/consumer/certification/wd042002/install/Gama_web.EXE> 


\section{APPENDIX B: MANUFACTURER MODEL NUMBERS}

\section{LIST OF TABLES}

Table B.1.1 Amana Furnace Model Number Description for GUID045CA30 . . . . . . . . . B-1

Table B.1.2 Carrier Model Number Description for $58 \mathrm{WAV} \ldots \ldots \ldots \ldots \ldots \ldots \ldots \ldots \ldots$. . . . . . . . . . . . . . .

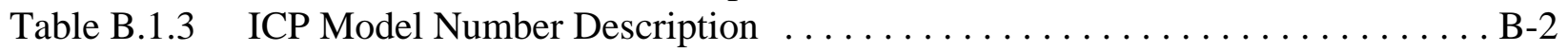

Table B.1.4 Goodman Model Number Description . . . . . . . . . . . . . . . . . . B-2

Table B.1.5 Lennox Model Number Description $\ldots \ldots \ldots \ldots \ldots \ldots \ldots \ldots \ldots \ldots \ldots$. . . . . . .

Table B.1.6 Armstrong Model Number Description . . . . . . . . . . . . . . . . . . . . . B-2

Table B.1.7 Trane/American Standard Model Number Description . . . . . . . . . . . . . . . B-3

Table B.1.8 Rheem Non-Condensing Model Number Description . . . . . . . . . . . . . . . B-3

Table B.1.9 Rheem Condensing Model Number Description . . . . . . . . . . . . . . . B-3

Table B.1.10 York Furnace Model Number Description $\ldots . . \ldots \ldots \ldots \ldots \ldots \ldots$. . . . . B-4

Table B.1.11 Nordyne Model Number Description $\ldots \ldots \ldots \ldots \ldots \ldots \ldots \ldots \ldots$. . . . . . 


\section{APPENDIX B: MANUFACTURER MODEL NUMBERS}

Manufacturers often code furnace specifications into their model numbers. This appendix illuminates the furnace specifications from their model numbers.

An Amana model number is as an example of how one manufacturer codes furnace characteristics. Table B.1.1 shows the Amana model number "GUID045CA30." The first row of the table shows the model number broken into eight cells. The fifth, sixth, and seventh characters of the model number are grouped together. The tenth and eleventh characters are grouped together. The second row gives an explanation for each character or group of characters. Row three deciphers the character or group. Deciphering the model number shows that this Amana furnace model is an upflow gas furnace with induced draft, a nominal output of $45 \mathrm{~K}$ Btuh, that is not $\mathrm{NO}_{\mathrm{x}}$ certified, and has an airflow capability of 3 tons.

Table B.1.1 Amana Furnace Model Number Description for GUID045CA30

\begin{tabular}{|l|l|l|l|l|l|l|l|}
\hline $\mathbf{G}$ & $\mathbf{U}$ & $\mathbf{I}$ & $\mathbf{D}$ & $\mathbf{0 4 5}$ & $\mathbf{C}$ & $\mathbf{A}$ & $\mathbf{3 0}$ \\
\hline $\begin{array}{l}\text { Product } \\
\text { Type }\end{array}$ & Supply Type & $\begin{array}{l}\text { Furnace } \\
\text { Type }\end{array}$ & $\begin{array}{l}\text { Model } \\
\text { Features }\end{array}$ & $\begin{array}{l}\text { Nominal } \\
\text { Input }\end{array}$ & $\begin{array}{l}\text { Design } \\
\text { Series }\end{array}$ & $\begin{array}{l}\text { Additional } \\
\text { Features }\end{array}$ & $\begin{array}{l}\text { Airflow } \\
\text { Capability }\end{array}$ \\
\hline $\begin{array}{l}\text { G: Gas } \\
\text { Furnace }\end{array}$ & U: Upflow & $\begin{array}{l}\text { I: Induced } \\
\text { Draft } \\
(80 \%)\end{array}$ & $\begin{array}{l}\text { D: Air } \\
\text { Command } \\
\text { 80 SV } \\
\text { (Category I } \\
\text { Venting) }\end{array}$ & $\begin{array}{l}\text { 045: } \\
45,000 \\
\text { Btuh }\end{array}$ & $\begin{array}{l}\text { C: Third } \\
\text { Series }\end{array}$ & $\begin{array}{l}\text { A: } \\
\text { Standard } \\
\text { Unit (not } \\
\text { NOx } \\
\text { certified) }\end{array}$ & 30: 3 Tons \\
\end{tabular}

All manufacturers have similar coding schemes for their furnace model numbers. Tables B.1.1-B.1.11 show model numbers from the major manufacturers and an explanation of their conventions.

Table B.1.2 Carrier Model Number Description for 58WAV

\begin{tabular}{|c|c|c|c|}
\hline 58WAV & 045 & 150 & 08 \\
\hline Furnace Series Configuration/Type & $\begin{array}{l}\text { Input Capacity } \\
\text { (btu/h) }\end{array}$ & Series Number & $\begin{array}{l}\text { Nominal Cooling Size (Airflow) } \\
\text { (400 CFM per 12,000 btu/h) }\end{array}$ \\
\hline $\begin{array}{l}\text { 58WAV = High Efficiency Induced } \\
\text { Combustion Upflow Furnace }\end{array}$ & $\begin{array}{l}045=44,000 \\
070=66,000 \\
091=88,000 \\
111=110,000 \\
136=132,000 \\
155=154,000\end{array}$ & & $\begin{array}{l}08=800 \text { CFM } \\
12=1200 \text { CFM } \\
14=1400 \text { CFM } \\
16=1600 \text { CFM } \\
20=2000 \text { CFM }\end{array}$ \\
\hline
\end{tabular}


Table B.1.3 ICP Model Number Description

\begin{tabular}{|c|c|c|c|c|c|c|c|c|}
\hline $\mathbf{N}$ & 9 & MP & 2 & 075 & $\mathbf{F}$ & 12 & A & $\#$ \\
\hline $\begin{array}{l}\text { Brand } \\
\text { Identifier }\end{array}$ & Model Identifier & Installatin Configuration & $\begin{array}{l}\text { Major Design } \\
\text { Feature }\end{array}$ & $\begin{array}{l}\text { Heating } \\
\text { Input } \\
\text { (mbtu/h) }\end{array}$ & $\begin{array}{l}\text { Cabinet } \\
\text { Width } \\
\text { (inches) }\end{array}$ & $\begin{array}{l}\text { Cooling } \\
\text { Airflow }\end{array}$ & $\begin{array}{c}\text { Marketing } \\
\text { Digit }\end{array}$ & $\begin{array}{c}\text { Engineering } \\
\text { Rev. }\end{array}$ \\
\hline $\begin{array}{l}\mathrm{N}=\text { Non-Brand } \\
\text { Specific } \\
\text { (Generic) } \\
\mathrm{T}=\text { Tempstar }\end{array}$ & $\begin{array}{l}8=\text { Non- } \\
\text { Condensing } \\
9=\text { Condensing }\end{array}$ & $\begin{array}{l}\text { MP = Multiposition } \\
\text { UP = Upflow } \\
\text { DN = Downflow } \\
\text { UH = Uplfow } / \text { Horizontal } \\
\text { HZ = Horizontal } \\
\text { DH = Downflow } / \\
\text { Horizontal }\end{array}$ & $\begin{array}{l}1=\text { One pipe } \\
2=\text { Two pipe } \\
\text { D = } 1 \text { or } 1 \text { pipe } \\
\text { L = Low Nox } \\
\text { N = Single Stage } \\
\text { P PVC Vent } \\
\text { T = Two Stage } \\
\text { V = Variable Speed }\end{array}$ & & $\begin{array}{l}B=15.5^{\prime \prime} \\
J=22.8^{\prime \prime} \\
F=19.1^{\prime \prime} \\
L=24.5^{\prime \prime}\end{array}$ & $\begin{array}{l}08=800 \\
12=1200 \\
14=1400 \\
16=1600 \\
20=2000\end{array}$ & $\begin{array}{l}\text { Denotes } \\
\text { minor } \\
\text { change }\end{array}$ & $\begin{array}{l}\text { Denotes } \\
\text { minor } \\
\text { change }\end{array}$ \\
\hline
\end{tabular}

Table B.1.4 Goodman Model Number Description

\begin{tabular}{|c|c|c|}
\hline GMNT & $\mathbf{0 4 0}$ & $\mathbf{3}$ \\
\hline Unit Type & $\begin{array}{c}\text { Input Capacity } \\
\text { (Btu/h) }\end{array}$ & $\begin{array}{c}\text { Nominal Cooling Capacity } \\
\text { (tons) }\end{array}$ \\
\hline GMNT = Multi-position gas furnace & $040=40,000 \mathrm{Btu} / \mathrm{h}$ & $3=3$ tons \\
\hline
\end{tabular}

Table B.1.5 Lennox Model Number Description

\begin{tabular}{|c|c|c|c|c|c|c|}
\hline G & 40 & UH & 24 & A & 045 & $\mathbf{X}$ \\
\hline Unit Type & Series & Configuration & $\begin{array}{l}\text { Nominal Ad- } \\
\text { On Cooling } \\
\text { Capacity }\end{array}$ & $\begin{array}{l}\text { Cabinet } \\
\text { Width }\end{array}$ & $\begin{array}{l}\text { Heating Input } \\
\text { (btu/h) }\end{array}$ & $\begin{array}{l}\text { CA emission } \\
\text { requirements }\end{array}$ \\
\hline $\begin{array}{l}\mathrm{G}=\text { Gas } \\
\text { Furnace }\end{array}$ & $\begin{array}{l}40=\text { Merit Series } 80 \% \\
50=\text { Elite } 80 \% \\
60=\text { 2-stage } 80 \%\end{array}$ & $\begin{array}{l}\mathrm{UH}=\text { Upflow/Horizontal } \\
\mathrm{DF}=\text { Downflow/Horizontal }\end{array}$ & $\begin{array}{l}24=2 \text { Tons } \\
36=3 \text { Tons } \\
48=4 \text { Tons } \\
60=5 \text { Tons }\end{array}$ & $\begin{array}{l}\mathrm{A}=14-1 / 2 \\
\mathrm{~B}=17-1 / 2 \\
\mathrm{C}=21 \\
\mathrm{D}=24-1 / 2\end{array}$ & $\begin{array}{l}045=44,000 \\
070=66,000 \\
090=88,000 \\
110=110,000 \\
135=132,000 \\
155=154,000\end{array}$ & $\begin{array}{l}\mathrm{X}=\text { meets } \\
\text { California NOX } \\
\text { standards }\end{array}$ \\
\hline
\end{tabular}

Table B.1.6 Armstrong Model Number Description

\begin{tabular}{|c|c|c|c|c|c|c|c|c|c|c|}
\hline G & $1 \mathrm{~N}$ & 80 & $\mathbf{A}$ & $\mathbf{H}$ & 100 & D & 20 & B & & $1 \mathrm{~A}$ \\
\hline $\begin{array}{c}\text { Product } \\
\text { Family }\end{array}$ & Furnace Type & $\begin{array}{l}\text { Nominal } \\
\text { AFUE }\end{array}$ & Series & Configuration & $\begin{array}{c}\text { Heating } \\
\text { Input } x \\
1000 \\
\text { (btu/h) }\end{array}$ & $\begin{array}{l}\text { Motor } \\
\text { Type }\end{array}$ & $\begin{array}{c}\text { Nominal } \\
\text { Maximum } \\
\text { CFM x } 100\end{array}$ & $\begin{array}{l}\text { Cabinet } \\
\text { Width }\end{array}$ & $\begin{array}{l}\text { Low } \\
\text { NOx } \\
\text { Model }\end{array}$ & Series \\
\hline & $\begin{array}{l}1 \mathrm{~N}=\text { Single Stage } \\
\text { Heat, Non-Direct Vent } \\
1 \mathrm{D}=\text { Single Stage } \\
\text { Heat, Direct Vent } \\
2 \mathrm{D}=\text { Two Stage Heat, } \\
\text { Direct Vent }\end{array}$ & & & $\begin{array}{l}\mathrm{H}=\text { Horizontal } \\
\mathrm{U}=\text { Upflow } \\
\mathrm{T}=\text { Upflow/ } \\
\text { Horizontal } \\
\mathrm{R}=\text { Downflow/ } \\
\text { Horixontal }\end{array}$ & & $\begin{array}{l}\mathrm{D}=\text { Direct } \\
\text { Drive }\end{array}$ & & $\begin{array}{l}\mathrm{A}=13-1 / 2 \\
\mathrm{~B}=17 \\
\mathrm{C}=20-1 / 2\end{array}$ & $\begin{array}{l}\mathrm{L}= \\
\text { Low } \\
\text { NOx } \\
\text { Model }\end{array}$ & \\
\hline
\end{tabular}


Table B.1.7 Trane/American Standard Model Number Description

\begin{tabular}{|c|c|c|c|c|c|c|c|c|}
\hline $\mathbf{T}$ & $\mathbf{U}$ & $\mathbf{Y}$ & 080 & $\mathbf{R}$ & 9 & V3 & $\mathbf{V}$ & 0 \\
\hline $\begin{array}{l}\text { Brand } \\
\text { Identifier }\end{array}$ & $\begin{array}{c}\text { Furnace } \\
\text { Configuration }\end{array}$ & Type & $\begin{array}{l}\text { Heating } \\
\text { Input } \\
(\mathrm{mbtu} / \mathrm{h})\end{array}$ & $\begin{array}{l}\text { Major Design } \\
\text { Change }\end{array}$ & $\begin{array}{c}\text { Power } \\
\text { Supply } \\
\text { and Fuel }\end{array}$ & $\begin{array}{l}\text { Airflow Capacity } \\
\text { for Cooling } \\
\text { (400 CFM/Ton) }\end{array}$ & $\begin{array}{l}\text { Minor Design } \\
\text { Change or }\end{array}$ & $\begin{array}{l}\text { Service } \\
\text { Digit }\end{array}$ \\
\hline $\begin{array}{l}\mathrm{T}=\text { Trane } \\
\mathrm{A}=\text { American } \\
\text { Standard }\end{array}$ & $\begin{array}{l}\mathrm{U}=\text { Upflow/ } \\
\text { Horizontal } \\
\mathrm{D}=\text { Downflow/ } \\
\text { Horizontal }\end{array}$ & $\begin{array}{l}\mathrm{C}=\text { Condensing } \\
\mathrm{D}=\text { Induced Draft } \\
\mathrm{E}=\text { Electronic Ignition } \\
\mathrm{X}=\text { Direct Vent } \\
\text { Condensing } \\
\mathrm{Y}=\text { Direct Vent } \\
\text { Condensing Variable } \\
\text { Speed }\end{array}$ & & $\begin{array}{l}\mathrm{C}=\text { Single Stage } \\
\mathrm{R}=\text { Two-Stage } \\
\text { All other = } \\
\text { Standard system }\end{array}$ & $\begin{array}{l}115 \\
\text { Volt/ } \\
\text { Natural } \\
\text { Gas }\end{array}$ & \begin{tabular}{|l}
$3=3$ Tons \\
V3 = 11/2-3 Tons, \\
Variable Speed \\
Motor (ICM) \\
V4 = 2 - 4 Tons, \\
Variable Speed \\
Motor (ICM) \\
V5 = 3 - 5 Tons, \\
Variable Speed \\
Motor (ICM)
\end{tabular} & $\begin{array}{l}\mathrm{H}=\text { Upflow/ } \\
\text { Horizontal } \\
\mathrm{V}=\text { Variable } \\
\text { Speed Motor }\end{array}$ & \\
\hline
\end{tabular}

Table B.1.8 Rheem Non-Condensing Model Number Description

\begin{tabular}{|c|c|c|c|c|c|c|c|c|c|}
\hline $\mathbf{R}$ & $\mathbf{G}$ & $\mathbf{P}$ & $\mathbf{J}$ & 07 & $\mathbf{E}$ & A & $\mathbf{U}$ & $\mathbf{E}$ & $\mathbf{R}$ \\
\hline $\begin{array}{l}\text { Brand } \\
\text { Identifier }\end{array}$ & Fuel Type & $\begin{array}{l}\text { Condensing } \\
\text { Furnace Type }\end{array}$ & Design Series & $\begin{array}{c}\text { Heating } \\
\text { Input } \\
\text { (kbtu/h) }\end{array}$ & $\begin{array}{l}\text { Ignition } \\
\text { Type }\end{array}$ & Variations & $\begin{array}{l}\text { Blower } \\
\text { Size }\end{array}$ & $\begin{array}{l}\text { Cooling } \\
\text { Designation } \\
\text { (CFM) }\end{array}$ & $\begin{array}{l}\text { Natural Gas } \\
\text { Fuel Code }\end{array}$ \\
\hline $\begin{array}{l}\mathrm{R}=\text { Rheem } \\
\mathrm{U}=\text { Ruud } \\
\mathrm{W}= \\
\text { Weatherking }\end{array}$ & $\begin{array}{l}\text { G = Natural } \\
\text { Gas }\end{array}$ & $\begin{array}{l}\mathrm{D}=\text { Upflow } \\
\mathrm{L}=\text { Downflow } \\
\mathrm{P}=\text { Upflow/ } \\
\text { Horizontal }\end{array}$ & $\begin{array}{l}\mathrm{J}=\text { Acclaim } \\
\mathrm{A}=\text { Acclaim II } \\
\mathrm{K}=\text { Acclaim II } \\
\text { Plus 2 } \\
\text { L = Acclaim II } \\
\text { Plus 2 LXE }\end{array}$ & $\begin{array}{l}04=45 \\
05=50 \\
06=67.5 \\
07=75 \\
10=100 \\
12=125 \\
15=150\end{array}$ & $\begin{array}{l}\text { E = Electric } \\
\text { Ignition } \\
\mathrm{N}=\text { Electric } \\
\text { Ignition - } \\
\text { NOx Model }\end{array}$ & $\begin{array}{l}\mathrm{A}= \\
\text { Standard } \\
\mathrm{B}=\text { Wide } \\
\text { Cabinet }\end{array}$ & $\begin{array}{l}\mathrm{U}=11 \mathrm{x} 6 \\
\mathrm{M}=11 \mathrm{x} 7 \\
\mathrm{R}=11 \mathrm{x} 10\end{array}$ & $\begin{array}{l}S=500-1200 \\
E=1100-1300 \\
G=1450-1750 \\
J=1900-2075\end{array}$ & $\begin{array}{l}\mathrm{R}=\mathrm{US} \\
\mathrm{A}=\text { Canada }\end{array}$ \\
\hline
\end{tabular}

Table B.1.9 Rheem Condensing Model Number Description

\begin{tabular}{|c|c|c|c|c|c|c|c|c|c|}
\hline $\mathbf{R}$ & G & $\mathbf{T}$ & $\mathbf{J}$ & 07 & $\mathbf{E}$ & $\mathbf{M}$ & $\mathbf{A}$ & $\mathbf{E}$ & S \\
\hline $\begin{array}{l}\text { Brand } \\
\text { Identifier }\end{array}$ & Fuel Type & $\begin{array}{c}\text { Condensing } \\
\text { Furnace Type }\end{array}$ & Design Series & $\begin{array}{c}\text { Heating } \\
\text { Input } \\
(\mathrm{kbtu} / \mathrm{h})\end{array}$ & $\begin{array}{l}\text { Ignition } \\
\text { Type }\end{array}$ & $\begin{array}{l}\text { Blower } \\
\text { Size }\end{array}$ & Variations & $\begin{array}{l}\text { Cooling } \\
\text { Designation } \\
\text { (CFM) }\end{array}$ & $\begin{array}{l}\text { Natural Gas } \\
\text { Fuel Code }\end{array}$ \\
\hline $\begin{array}{l}\mathrm{R}=\text { Rheem } \\
\mathrm{U}=\text { Ruud } \\
\mathrm{W}= \\
\text { Weatherking }\end{array}$ & $\begin{array}{l}\text { G = Natural } \\
\text { Gas }\end{array}$ & $\begin{array}{l}\mathrm{T}= \\
\text { Downflow/ } \\
\text { Horizontal } \\
\mathrm{R}=\text { Upflow } \\
\mathrm{M}=\text { Upflow } \\
\text { Modulating }\end{array}$ & $\begin{array}{l}J=\text { Classic } 90 \\
\text { A = Classic } 90 \\
\text { Plus } \\
D=\text { Classic } 90 \\
\text { Plus Modulating }\end{array}$ & $\begin{array}{l}04=45 \\
06=60 \\
07=75 \\
09=90 \\
10=105 \\
12=120\end{array}$ & $\begin{array}{l}\mathrm{E}=\text { Electric } \\
\text { Ignition } \\
\mathrm{N}=\text { Electric } \\
\text { Ignition - } \\
\text { (Low NOx) }\end{array}$ & $\begin{array}{l}\mathrm{M}=11 \mathrm{x} 7 \\
\mathrm{R}=11 \times 10 \\
\mathrm{Z}=12 \times 11 \\
\mathrm{Y}=12 \times 7\end{array}$ & $\begin{array}{l}\mathrm{A}= \\
\text { Standard } \\
\mathrm{B}=\text { Wide } \\
\text { Cabinet } \\
\mathrm{C}= \\
\text { Single/Mul } \\
\text { ti Zone }\end{array}$ & $\begin{array}{l}E=1100-1300 \\
G=1500-1700 \\
J=1900-2100 \\
K=600-1200 \\
M=1200-2000\end{array}$ & $\begin{array}{l}\mathrm{S}=\mathrm{US} \\
\mathrm{B}=\text { Canada }\end{array}$ \\
\hline
\end{tabular}


Table B.1.10 York Furnace Model Number Description

\begin{tabular}{|c|l|l|l|l|l|l|}
\hline $\mathbf{P 4}$ & HU & \multicolumn{1}{|c|}{$\mathbf{A}$} & $\mathbf{1 2}$ & $\mathbf{N}$ & $\mathbf{0 3 2}$ & $\mathbf{0 1}$ \\
\hline & $\begin{array}{c}\text { Furnace } \\
\text { Configuration }\end{array}$ & Cabinet Size Width & Design Series & & $\begin{array}{c}\text { Output Capacity } \\
\text { (btu/h) }\end{array}$ & \\
\hline & HU = Upflow & $\begin{array}{l}\mathrm{A}=14-1 / 2 \\
\mathrm{~B}=17-1 / 2 \\
\mathrm{C}=21 \\
\mathrm{D}=24-1 / 2\end{array}$ & $\begin{array}{l}12=1200 \text { CFM } \\
16=1600 \text { CFM } \\
20=2000 \text { CFM }\end{array}$ & & & $032=32,000$ \\
\end{tabular}

\section{Table B.1.11 Nordyne Model Number Description}

\begin{tabular}{|c|c|c|c|c|c|c|c|}
\hline G & 6 & $\mathbf{R}$ & $\mathbf{A}$ & 144 & C & 20 & C \\
\hline $\begin{array}{l}\text { Furnace } \\
\text { Fuel Type }\end{array}$ & $\begin{array}{c}\text { Design } \\
\text { Series }\end{array}$ & Furnace Type & Furnace Configuration & $\begin{array}{l}\text { Heating Input } \\
\text { (btu/h) }\end{array}$ & $\begin{array}{l}\text { Certification } \\
\text { Type }\end{array}$ & Nominal CFM & $\begin{array}{l}\text { Cabinet } \\
\text { Width }\end{array}$ \\
\hline $\begin{array}{l}\text { G, FG, } \\
\text { KG, L = } \\
\text { Gas }\end{array}$ & 6 or 1 & $\begin{array}{l}\mathrm{R}=\text { Residential } \\
\mathrm{T}=\text { Residential, two- } \\
\text { stage }\end{array}$ & $\begin{array}{l}\mathrm{A}=\text { Upflow } \\
\mathrm{C}=\text { Upflow, Condensing } \\
\mathrm{K}=\text { Downflow } \\
\mathrm{L}=\text { Downflow, condensing }\end{array}$ & $\begin{array}{l}045=45,000 \\
060=60,000 \\
072=72,000 \\
096=96,000 \\
120=120,000 \\
144=144,000\end{array}$ & $\begin{array}{l}\mathrm{C}=\text { US/Canada } \\
\mathrm{N}=\text { NOx US }\end{array}$ & $\begin{array}{l}08=800 \text { CFM } \\
12=1200 \text { CFM } \\
\text { V }=\text { Variable Speed }\end{array}$ & $\begin{array}{l}\mathrm{A}=14-1 / 4 \\
\mathrm{~B}=19-3 / 4 \\
\mathrm{C}=22-1 / 2\end{array}$ \\
\hline
\end{tabular}

We used this information along with product literature and installation manuals to develop a detailed database of furnace characteristics for models that are currently being sold. The database is available at http://www.eere.energy.gov/???? 


\section{APPENDIX C: BASIC FURNACE MODEL DETERMINATION}

\section{LIST OF FIGURES}

Figure C.1 Number of Non-Weatherized Furnace Models by Input Capacity . . . . . . . . C-2

Figure C.2 Frequency of Weatherized Gas Furnace Models by Input Capacity . . . . . . . . C-2

Figure C.3 Frequency of Manufactured Housing Gas Furnace Models by

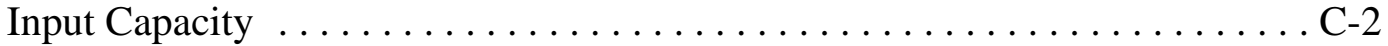

Figure C.4 Frequency of Oil Furnace Models by Input Capacity $\ldots \ldots \ldots \ldots \ldots \ldots \ldots$. . C-2 


\section{APPENDIX C: BASIC FURNACE MODEL DETERMINATION}

To determine basic furnace models, we selected 24 airflow/capacity bins. We selected the bins by looking at "common” (popular) sizes of input capacity and air handler size in the Gas Appliances Manufacturers Association (GAMA) Certified Efficiency Ratings database for the period April 2002 to October 2002 ${ }^{1}$. We assumed the frequency of models of a particular size indicated how common or popular the size was. Product literature and furnace manufacturer web sites helped in further determining series of furnaces considered to be "basic models". Therefore, we first reviewed the specifications for models as a precursor to picking the bins.

To determine the characteristics of basic furnace models of non-condensing non-weatherized gas furnace models (NWGF), we examined non-modulating, single-stage natural gas furnaces that are not intended for manufactured homes. In addition, we selected upflow and horizontal models since they represent the majority of models and often have similar or identical specifications and efficiency values as downflow models from the same manufacturer. (Of the 8342 models in the GAMA directory $77 \%$ were either horizontal or upflow). Similarly, only furnaces at or above $80 \%$ AFUE were picked since they represent the majority of non-weatherized gas furnaces. To further refine the basic model selection criteria, we used product literature to select models with non-variable speed PSC motors. Manufacturer web sites provided information categorizing their furnaces. This information further helped distinguish between the different series of models.

We used a similar process to select basic models for condensing non-weatherized gas furnaces. Model characteristics included non-modulating, single-stage furnace not intended for manufactured homes. Since many condensing gas furnaces series are multi-position (upflow, horizontal, downflow), we included downflow, upflow and horizontal models. We gleaned this information from the GAMA database. To further refine the selection criteria, we used product literature to select models with non-variable speed PSC motors.

We selected similar models that had the same capacity and nominal airflow (CFM). Most of the furnaces fit into four air flow sizes: 800 CFM (2 ton), 1200 CFM (3 ton), 1600 CFM (4 ton), 2000CFM (5 ton).

In terms of input capacity, most models fit into the 12 input capacity bins. Some models did not exactly match the bins, but had similar enough values to be considered in the same bin. For example, $40 \mathrm{KBtu} / \mathrm{h}$ and $45 \mathrm{KBtu} / \mathrm{h}$ models are grouped together into a single $45 \mathrm{KBtu} / \mathrm{h}$ bin. The 4 nominal airflow sizes and 12 input capacities were combined into bins. Only 24 of these bins are used in the analysis. Some combinations of nominal airflow size and input capacity are not manufactured.

Each of the 24 bins has at least two models, with the exception of 2 ton $50 \mathrm{KBtu} / \mathrm{h}$ noncondensing bin, $45 \mathrm{KBtu} / \mathrm{h} 2$ ton condensing bin, and 4 ton 115, 120, and $125 \mathrm{KBtu} / \mathrm{h}$ condensing bins. Finally, the $150 \mathrm{KBtu} / \mathrm{h} 5$ ton bin was not selected, since there are very few condensing models that are over $125 \mathrm{KBtu} / \mathrm{h}$ and none that are close to $150 \mathrm{KBtu} / \mathrm{h}$. 
The 12 different input capacities from $45 \mathrm{KBtu} / \mathrm{h}$ to $140 \mathrm{KBtu} / \mathrm{h}$ give a good range to match different home sizes.

Figures C.1 - C.4 show the frequency of models by input capacity for four of the six product classes

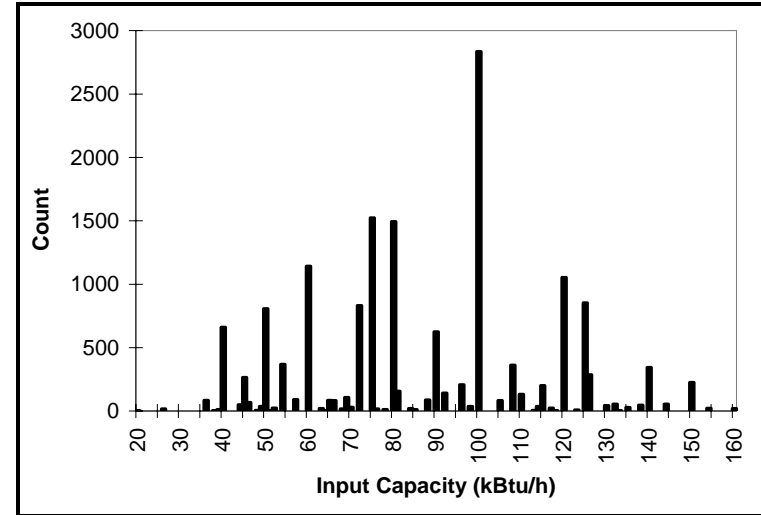

Figure C.1 Number of Non-Weatherized Furnace Models by Input Capacity

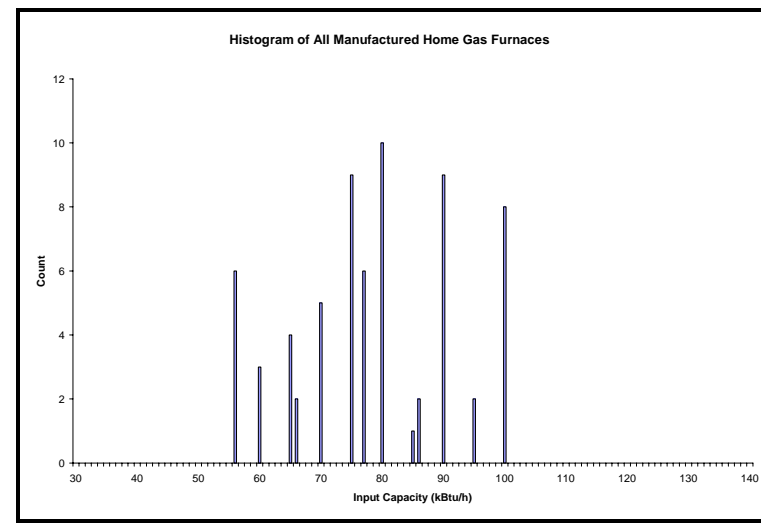

Figure C.3

\section{Frequency of Manufactured Housing Gas Furnace Models by Input Capacity}

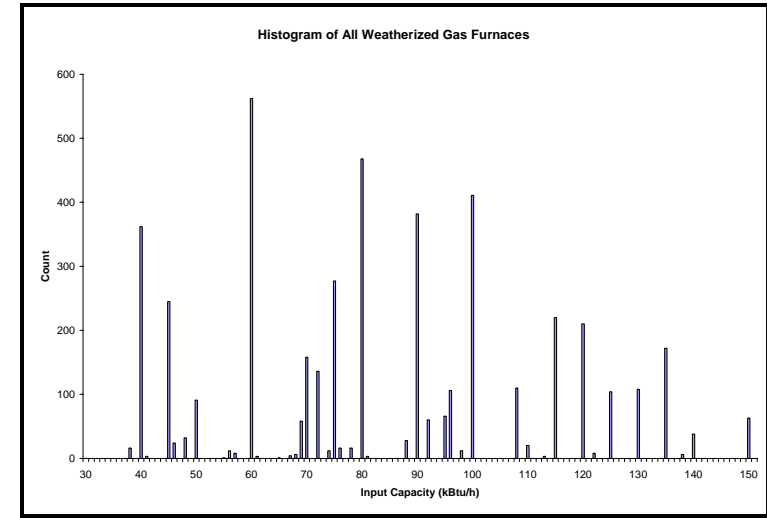
Figure C.2
Frequency of Weatherized Gas Furnace Models by Input Capacity

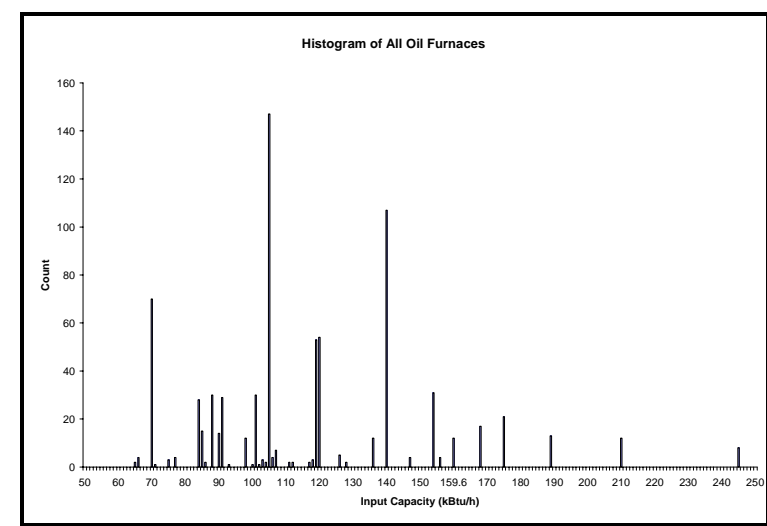

Figure C.4 Frequency of Oil Furnace Models by Input Capacity

The tables at the end of this appendix present model numbers and specifications for the non-condensing and condensing basic model non-weatherized gas furnaces used for the LCC analysis. 


\section{REFERENCES}

1. Gas Appliance Manufacturers Association, GAMA Directory Database, April 2002. Gas Appliance Manufacturers Association.

<http://www.gamanet.org/consumer/certification/wd042002/install/Gama_web.EXE> 


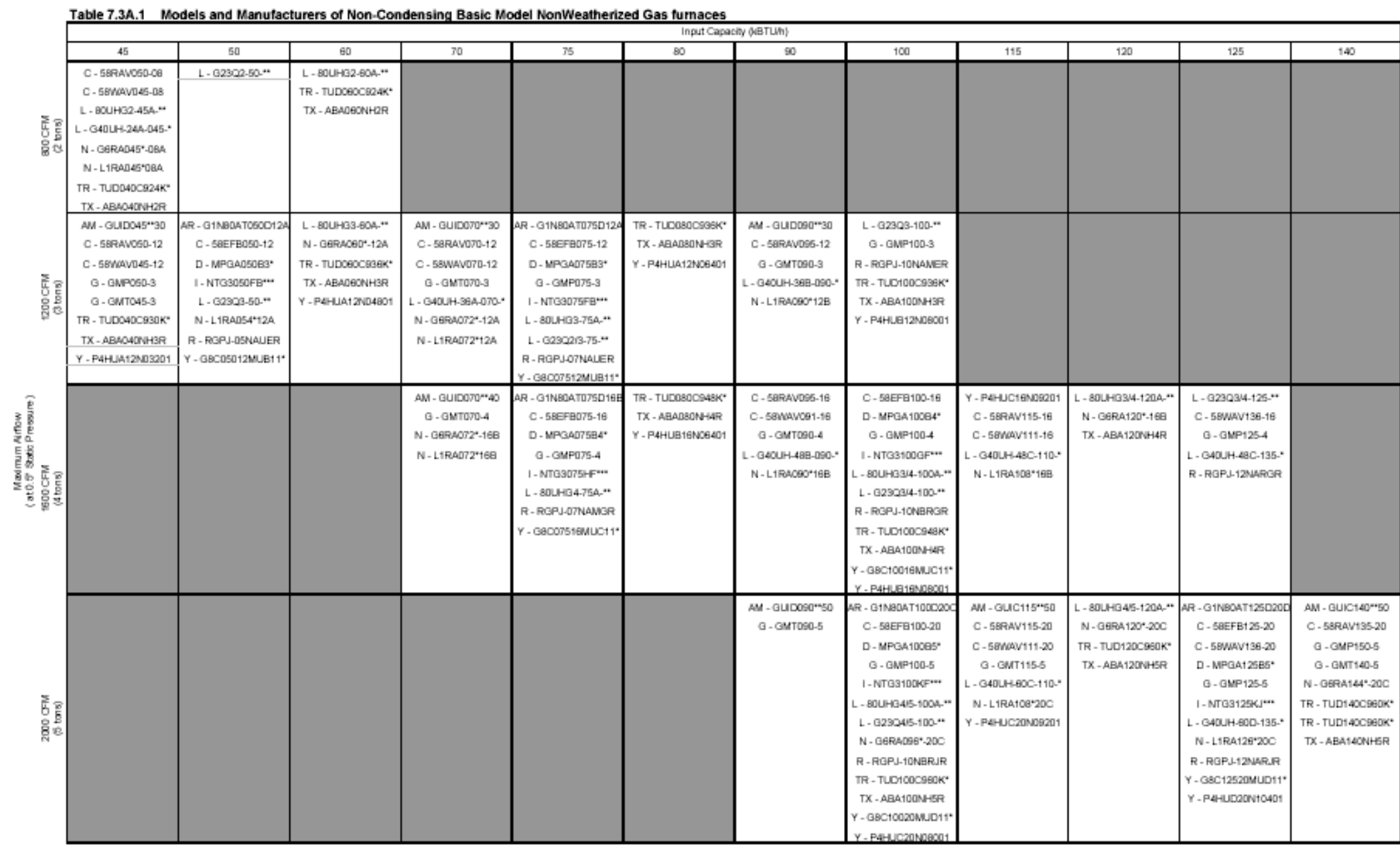

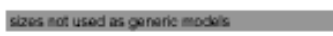

Manufacterer Key:

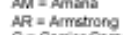

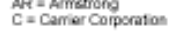

$D=$ Ducane
$Q=$ Goodiman

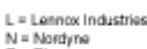

TR $=$ Trane
TX $=$ Toeses Fumace
$Y=$ York 


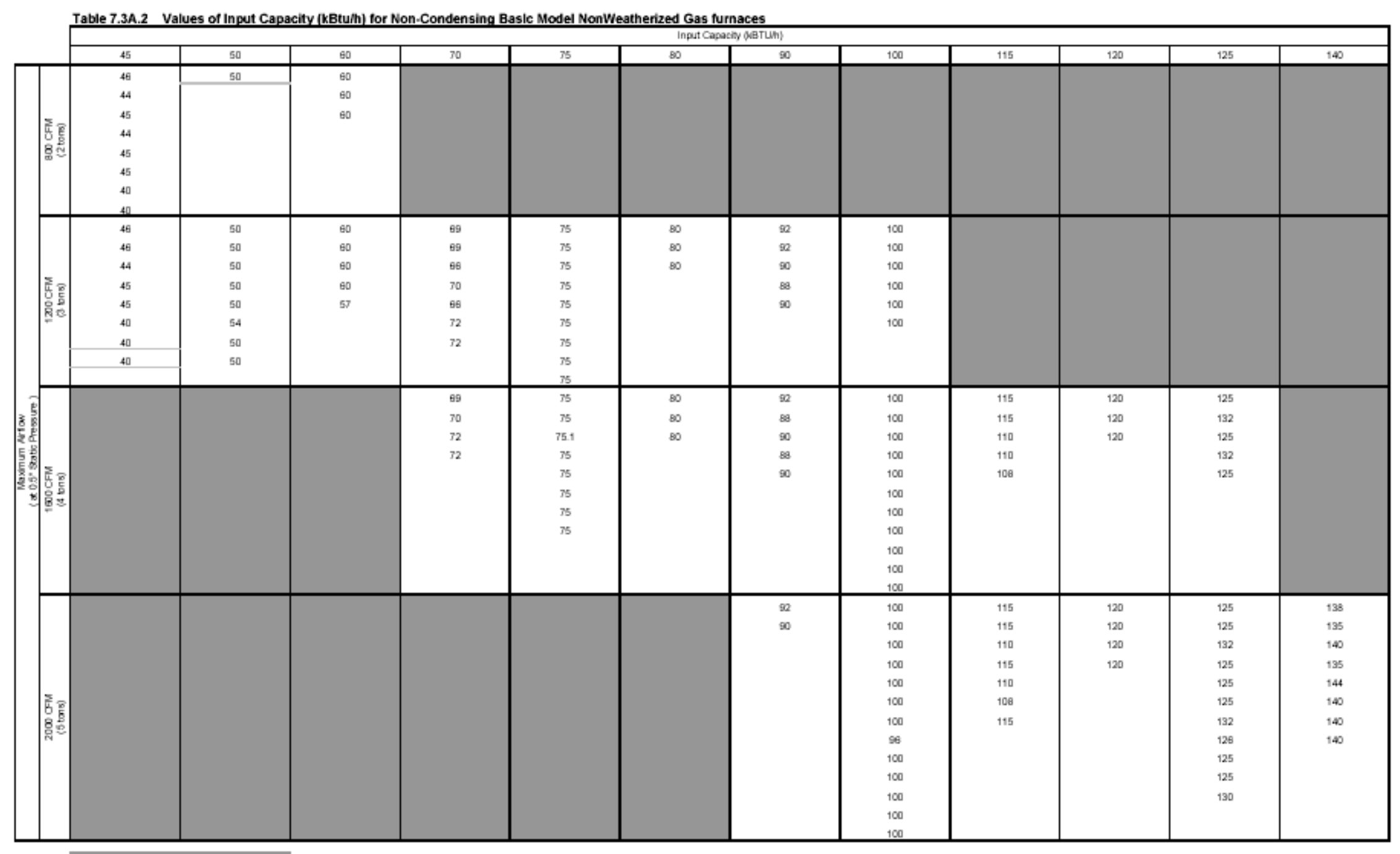

sizes not used as goneric modes 


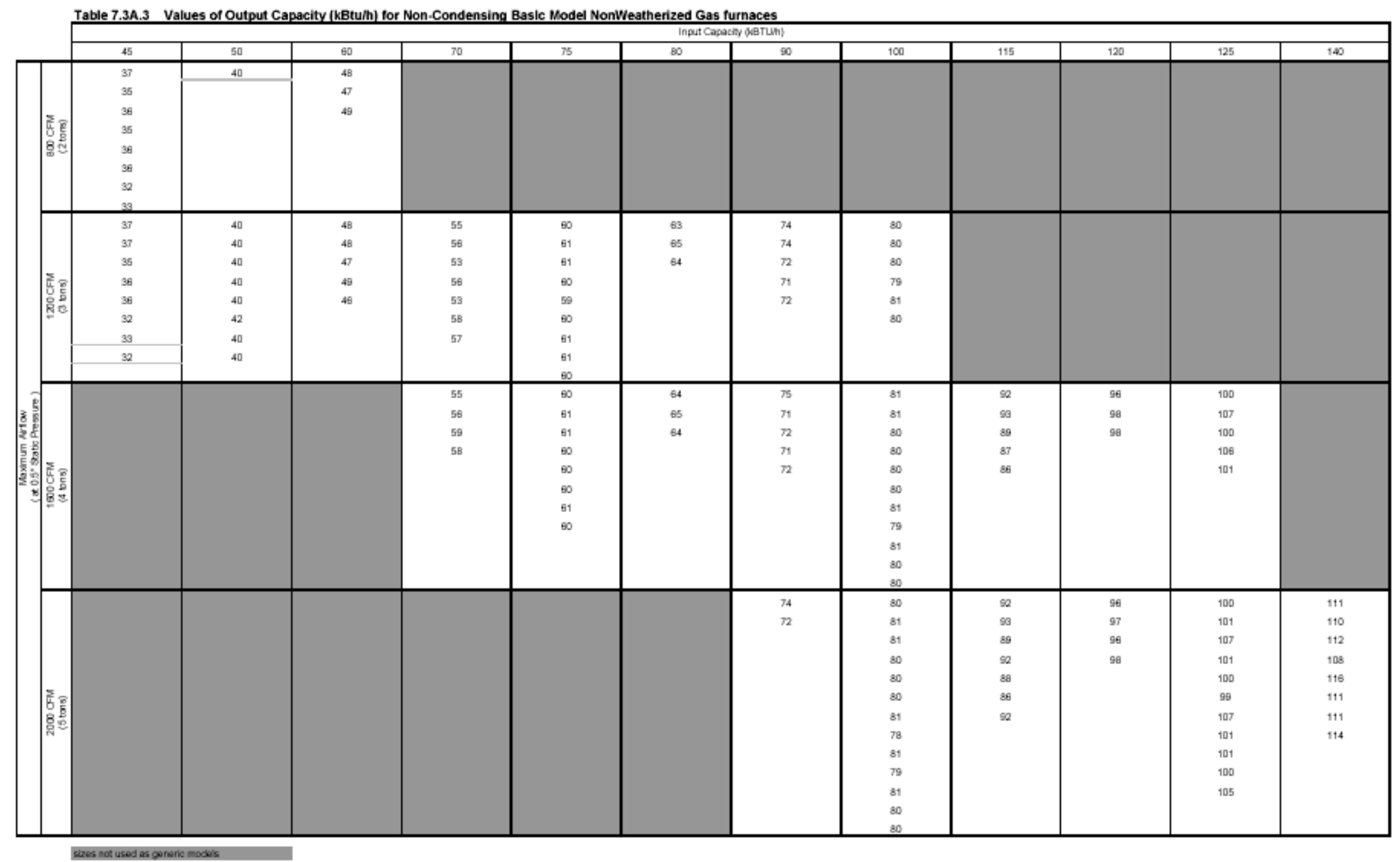


Table 7.3A.4 Values of Maximum CFM Q 0.5 In.w.c. for Non-Condensing Baslc Model NonWleatherized Gas furnaces

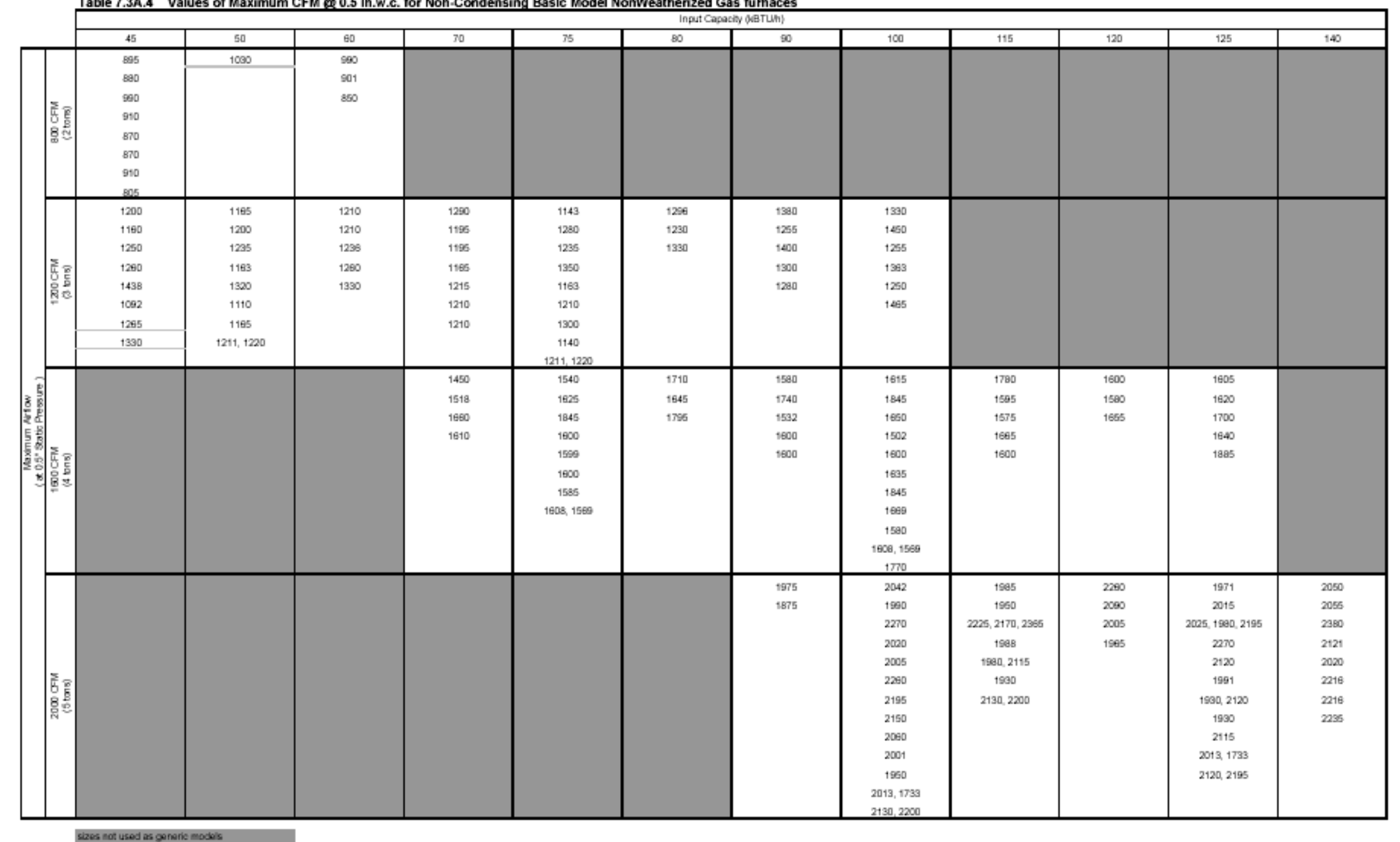


Table 7.3A.5 Values of Low CFM P 0.5 in.w.c. for Non-Condensing Baslc Model NonWleatherized Gas furnaces

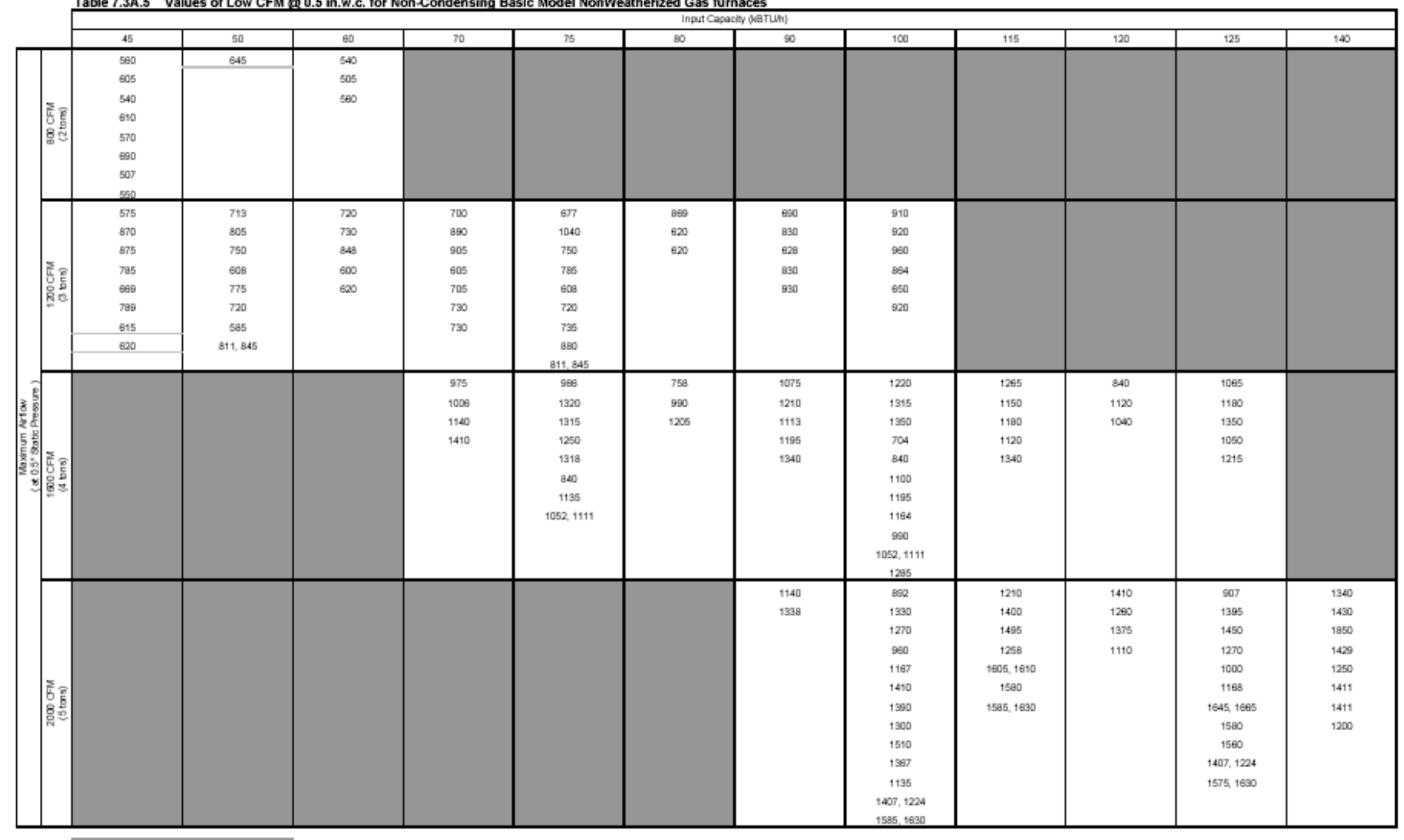

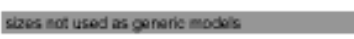


Table 7.3A.6 Values of Blower SIze (dlam X width) for Non-Condensing Baslc Model NonWheatherized Gas furmaces

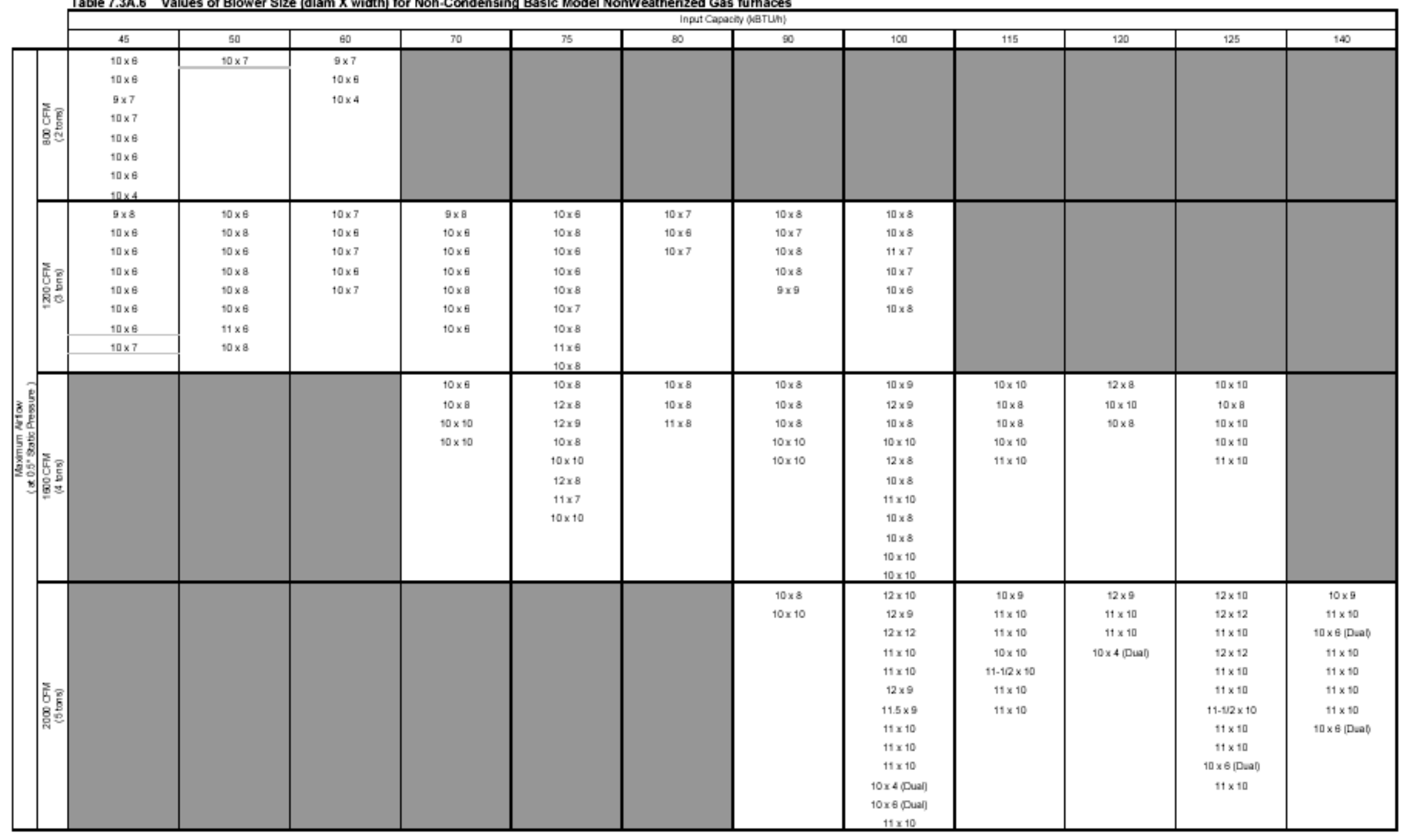

sizes not used as gonarie modes 
Table 7.3A.7 Values of Motor Size (hp) for Non-Condensing Basic Model NonWeatherized Gas fumaces

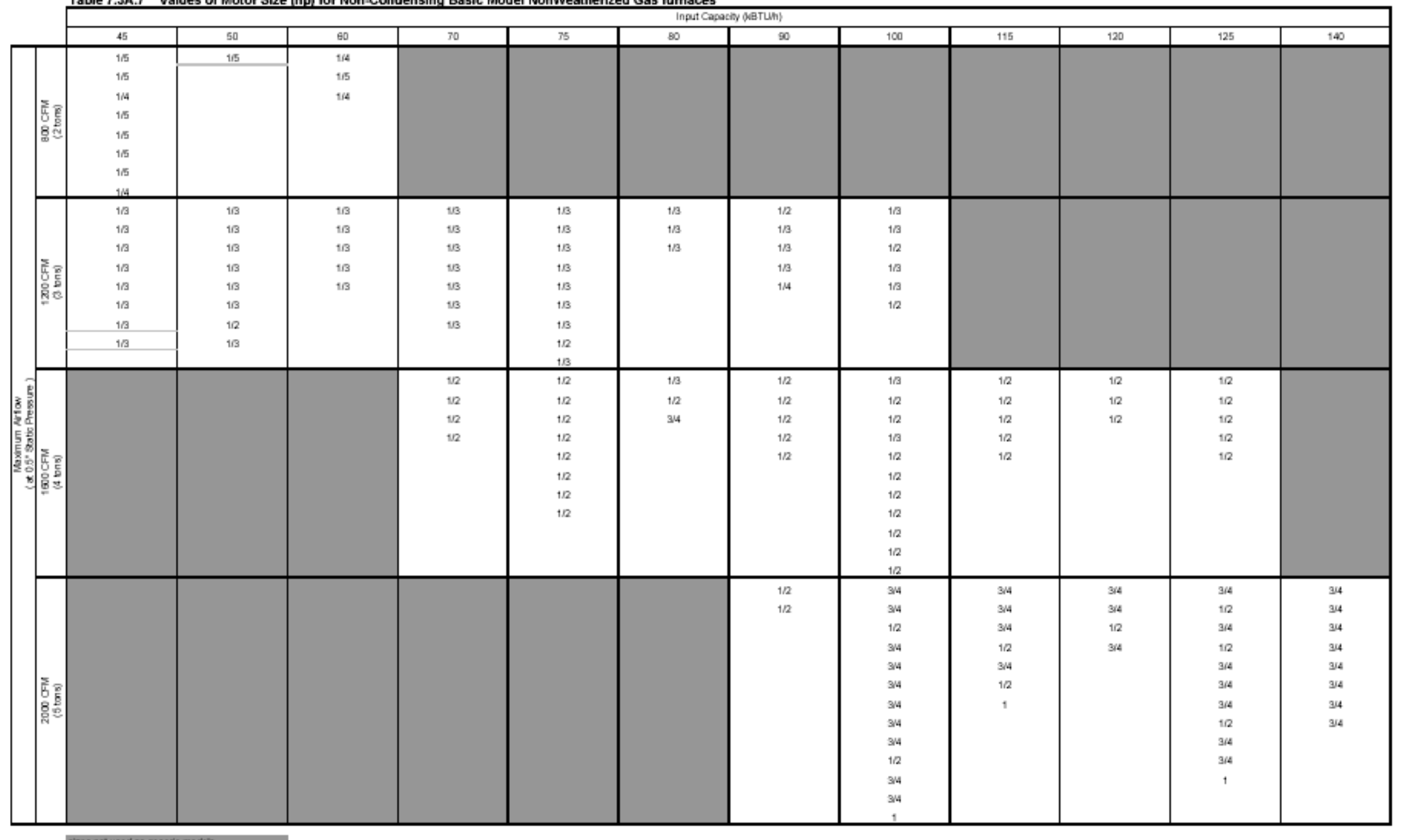

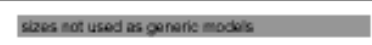


Table 7.3A.8 Number of Speed Taps for Non-Condensing Basic Model NonWeatherized Gas fumaces

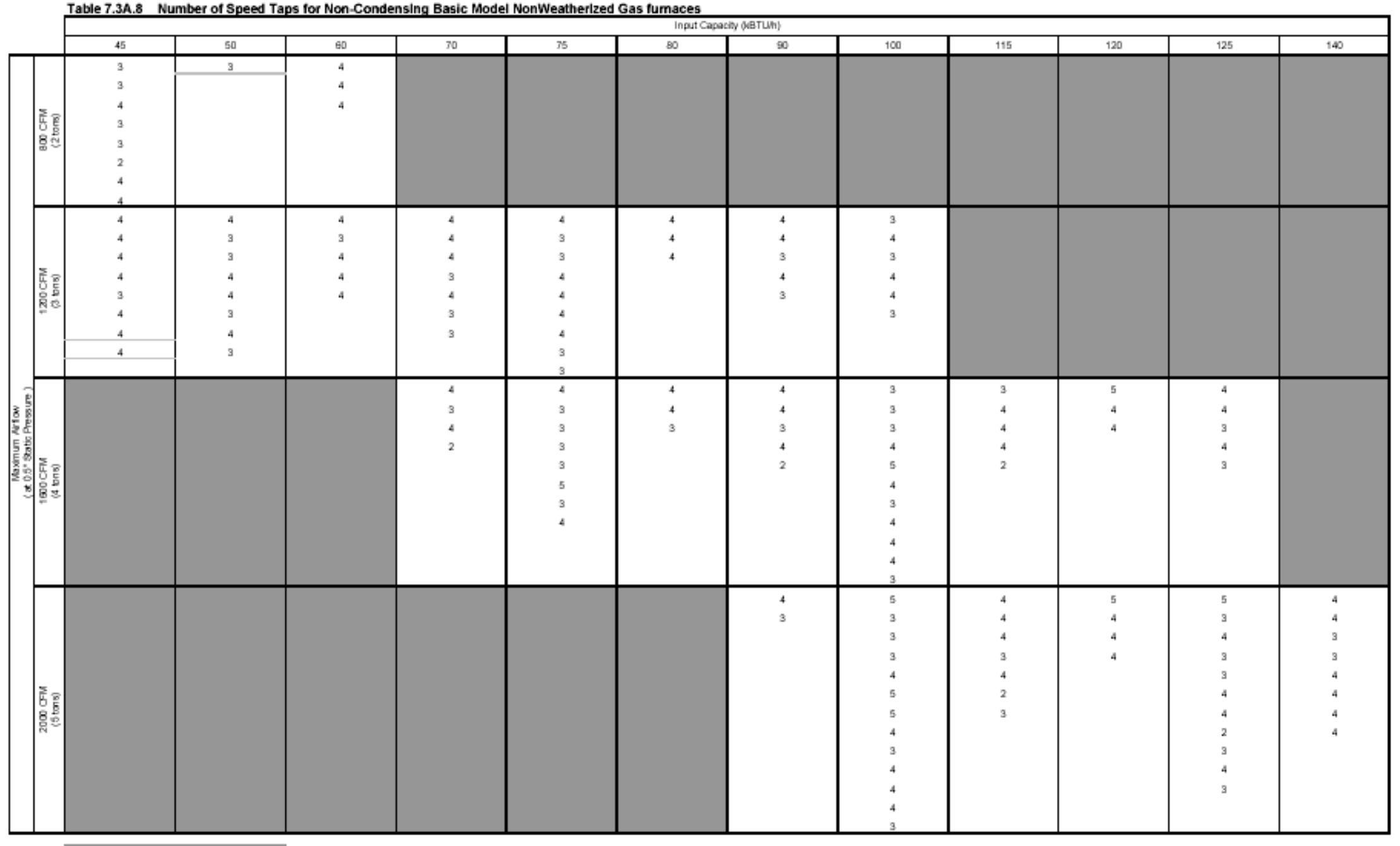

sices not used as gonerie moders 


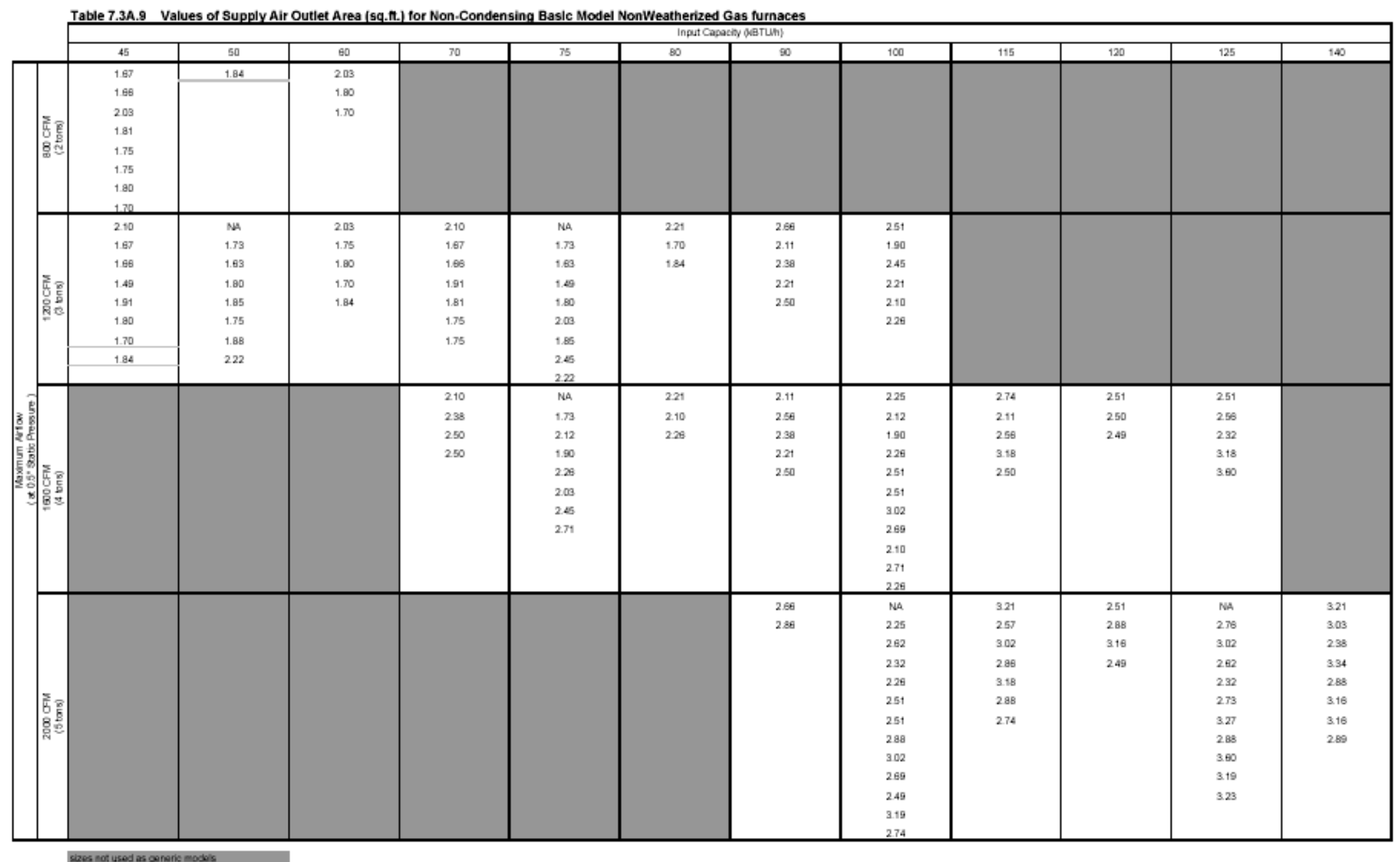




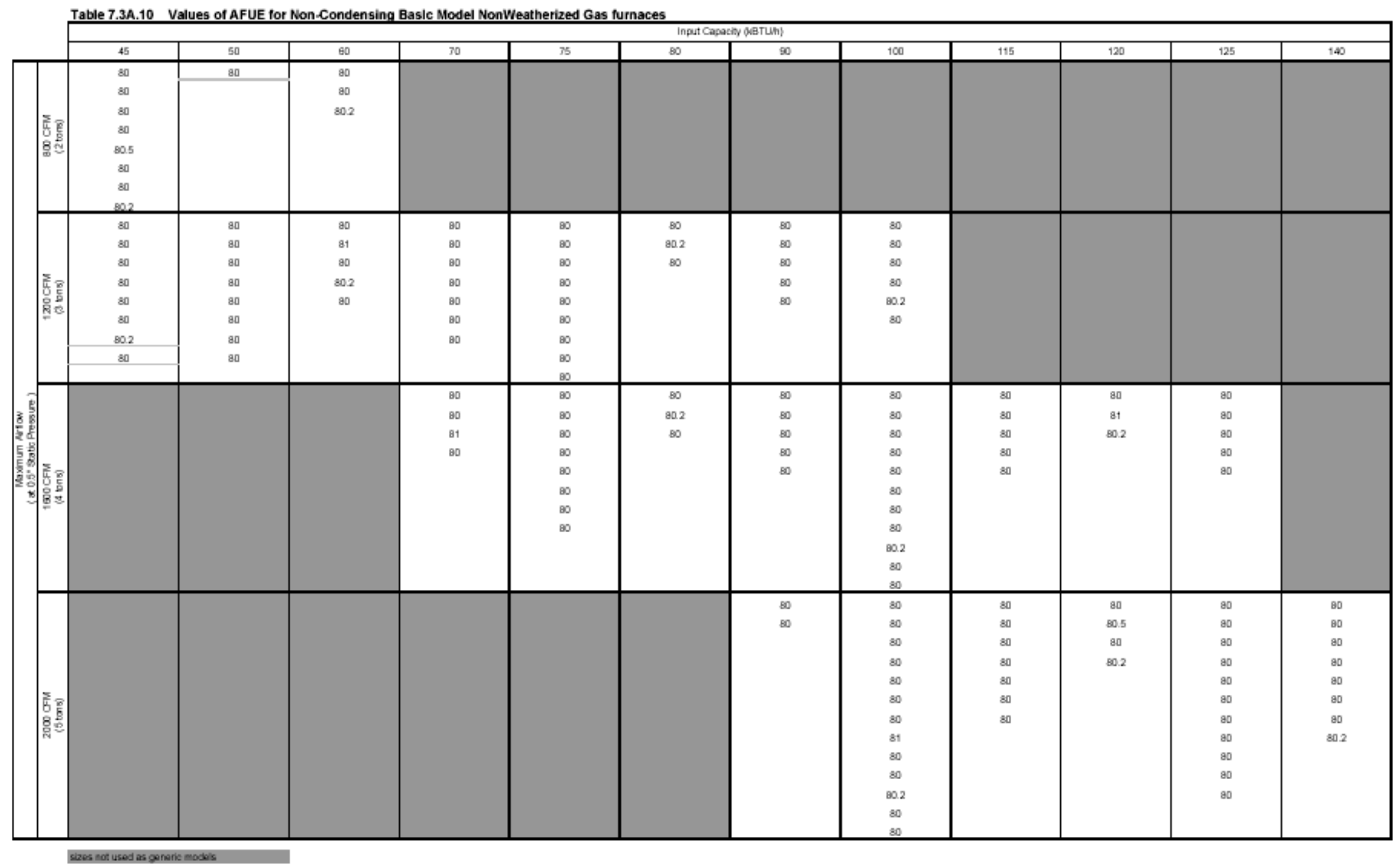

C-14 
Table 7.3A.13 Values of Pre-Purge Time (secs) for Non-Condensing Basic Model NonWeatherized Gas fumaces

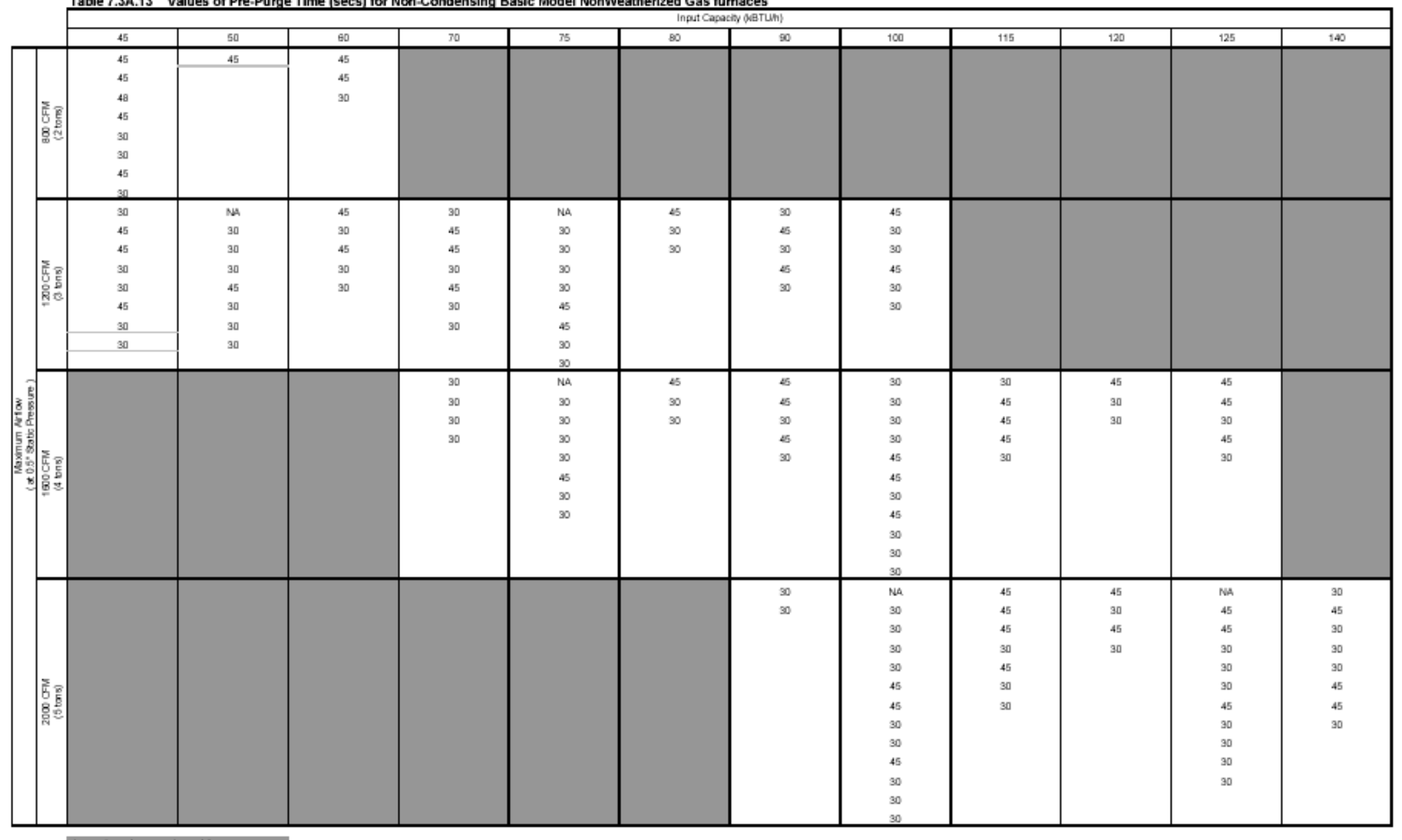

sizes not used as gonarie modes 


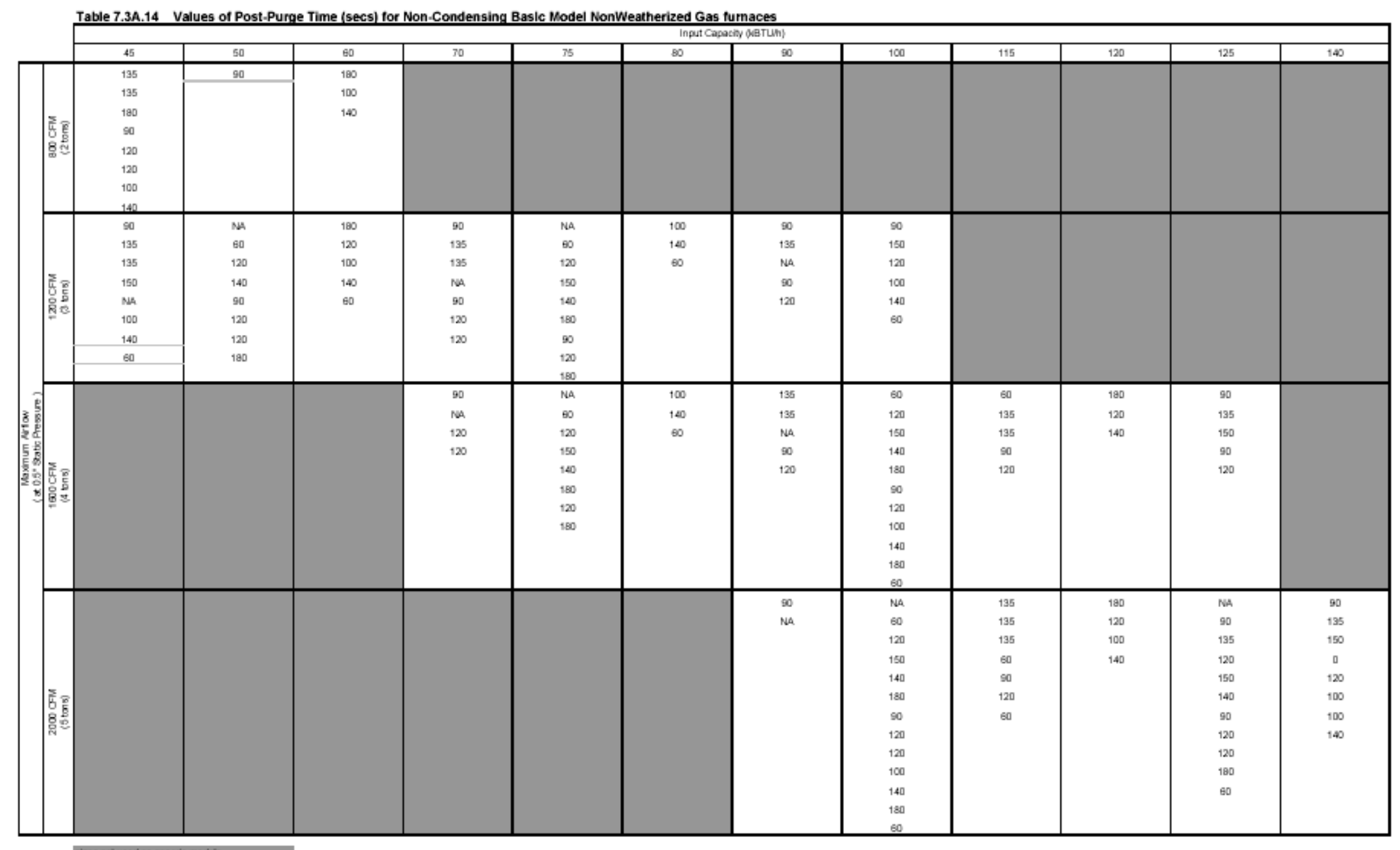


Table 7.3A.15 Values of On-Delay Time (secs) for Non-Condensing Baslc Model NonWeatherized Gas furnaces

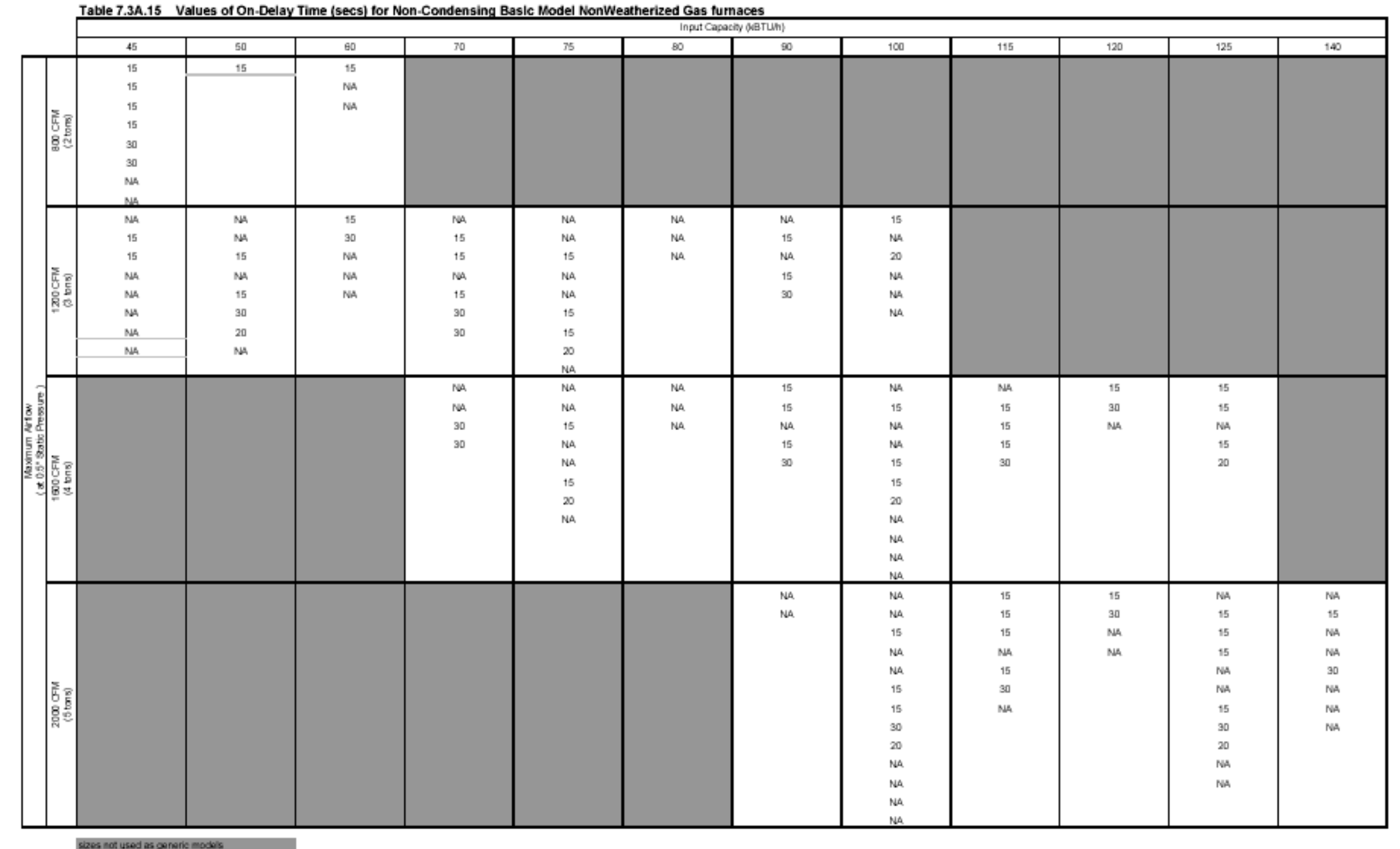

sizes not used as on pronte modes 


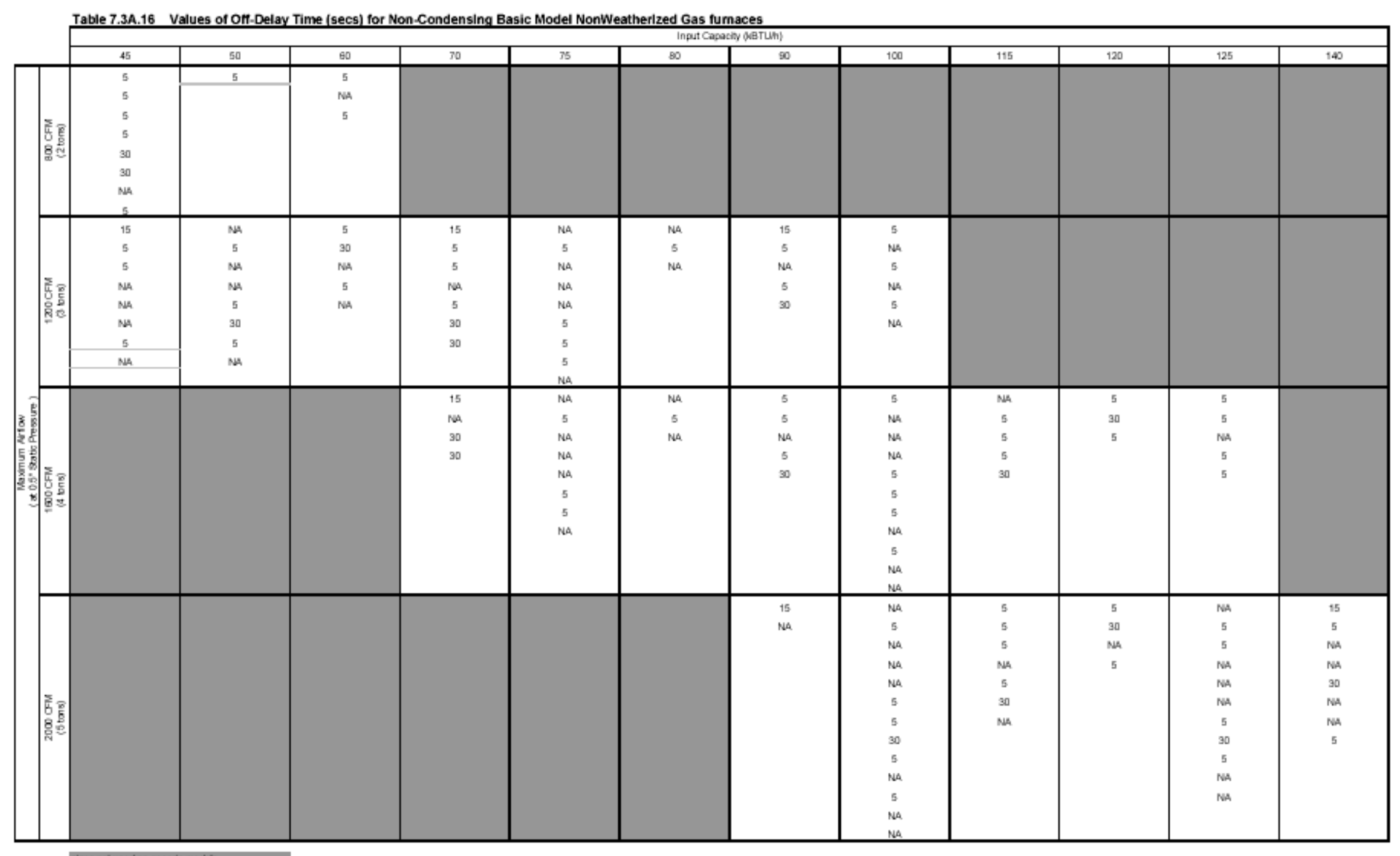

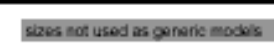




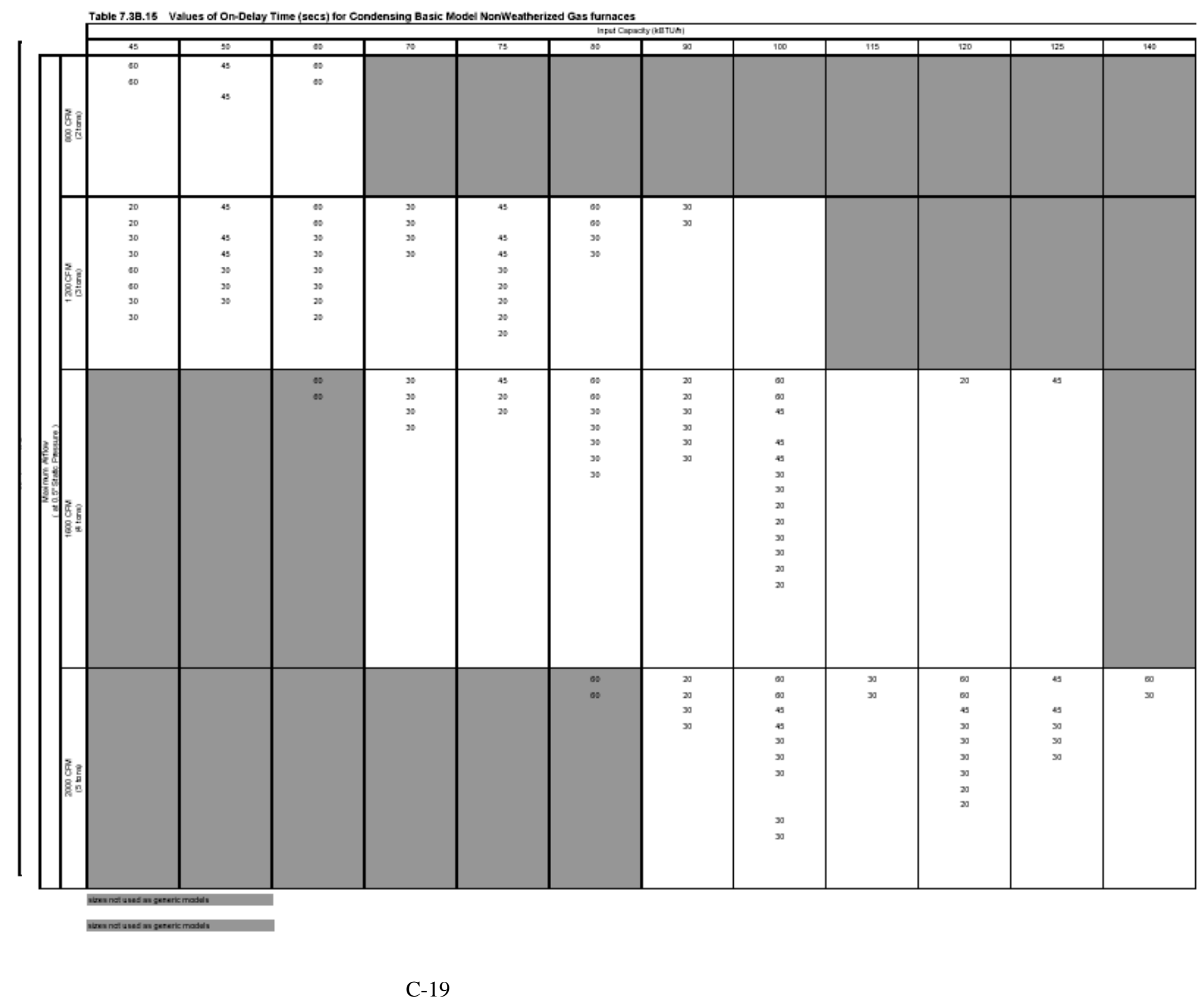




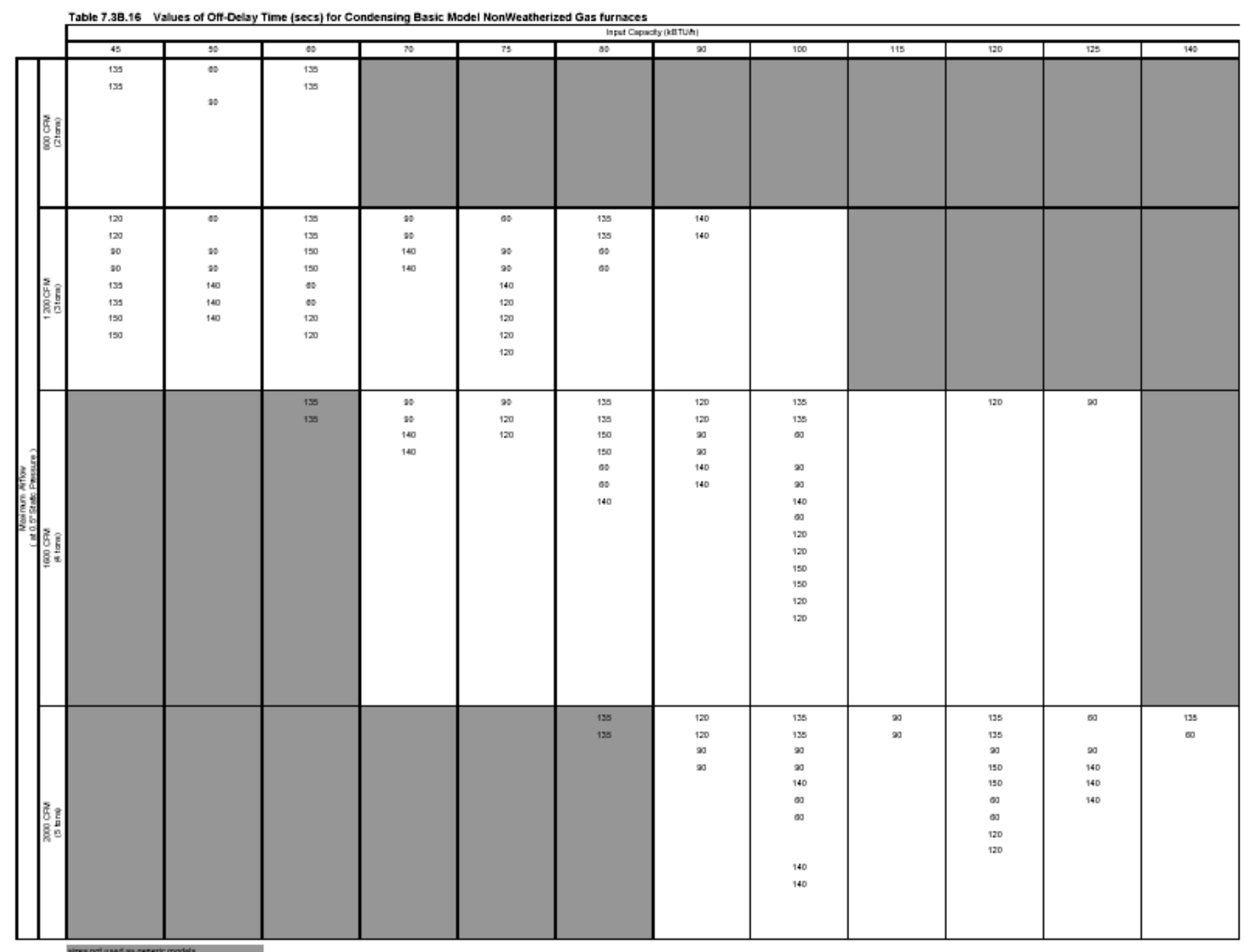

C-20 


\section{APPENDIX D: FURNACE FAN CURVES}

TABLE OF CONTENTS

D.1 GENERAL AIR SPEED AND AIRFLOW RELATIONSHIP . . . . . . . . . . D-1

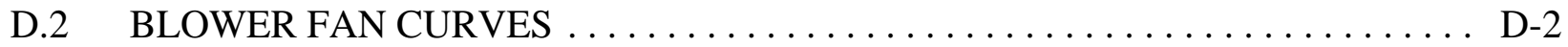

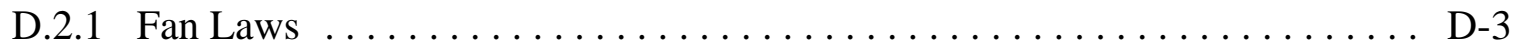

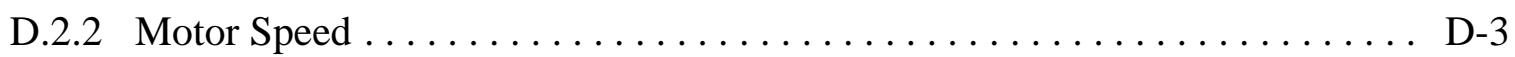

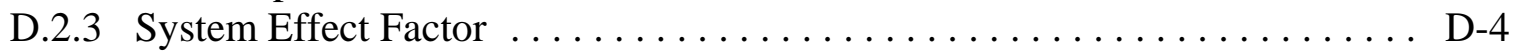

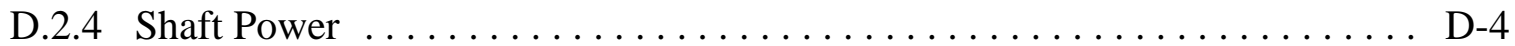

D.2.5 Fan Curves for Generic Model Furnaces ... . . . . . . . . . . . D

\section{LIST OF TABLES}

Table D.2.1 Coefficients for Static Pressure as a Function of Airflow $\ldots \ldots \ldots \ldots$. . D.1-5 


\section{APPENDIX D: FURNACE FAN CURVES}

Furnace energy consumption includes motor electricity from the motor of the circulating air blower. The furnace blower electricity use depends on air flow through the furnace and the pressure rise across the furnace. A fan curve is a graphical representation of the pressure rise, called static pressure, compared to the airflow through the fan or blower. The blower fan curve shows the static pressure and airflow that the blower will provide at a given motor speed. A blower fan curve represents the performance of the blower alone without the furnace. The furnace fan curve shows the static pressure compared to airflow through the furnace.

A furnace fan has three operational modes: cooling (when central air conditioning is present), normal heating, and low-fire heating. This appendix details the Department's methods for determining the generic model furnace fan curves for cooling operation type. For the normal heating or low-fire heating operation, DOE fit the basic model fan curves directly to develop equations of static pressure versus air flow across the furnace.

Blower manufacturers provide blower fan curves for both static pressure and shaft power as functions of airflow. The Department combined the blower fan curves with assumptions about the furnace airflow and motor performance to derive furnace fan curves for generic model furnaces.

\section{D.1 GENERAL AIR SPEED AND AIRFLOW RELATIONSHIP}

Blowers are the component inside the furnace that moves the air through the furnace. All the air that moves through the furnaces also goes through the blower.

Many furnace components, such as the heat exchangers, the inlet and outlet openings, and the geometry of the enclosure, partially obstruct or restrict the airflow. The decrease in the pressure rise due to putting a blower into the furnace enclosure is a system effect factor (SEF). SEF a pressure loss which recognizes the effect of fan inlet restrictions, fan outlet restrictions, or other conditions influencing fan performance when installed in the system. ${ }^{1}$ The difference between the blower pressure and the external static pressure across the furnace at the same airflow is due to the SEF. The SEF varies as the square of the air velocity.

For any given furnace model, the air velocity at the blower is directly proportional to airflow through the furnace. Thus, the pressure across the furnace can be calculated as

$$
P_{\text {furn }}=P_{\text {blower }}(Q, N)-S E F \times Q^{2}
$$


where

$$
\begin{array}{ll}
P_{\text {furn }} & =\text { furnace static pressure (in.w.g.) } \\
P_{\text {blower }} & =\text { static pressure across blower alone (in.w.g.) } \\
Q & =\text { airflow (cfm) } \\
N & =\text { motor speed (rpm) } \\
S E F & =\text { system effect factor }
\end{array}
$$

\section{D.2 BLOWER FAN CURVES}

The Department chose four blowers from Lau Industries, a manufacturer that supplies blowers to the furnace industry, to match with four generic model furnace blowers ${ }^{2}$ (see section 7.2 for a discussion of generic furnaces). The Department first determined equations for the blower fan curves. The Department fit third- and fourth-order polynomial equations of air flow to the pressure and shaft power curves of these blowers. (See Appendix 5, Blower Fan Curves, for more details.)

$$
P\left(Q, N_{\text {test }}\right)=c_{p 0}+c_{p 1} \cdot\left(\frac{Q}{1000}\right)+c_{p 2} \cdot\left(\frac{Q}{1000}\right)^{2}+c_{p 3} \cdot\left(\frac{Q}{1000}\right)^{3}+c_{p 4} \cdot\left(\frac{Q}{1000}\right)^{4}
$$

where

$$
\begin{array}{ll}
P_{\text {blower }} & =\text { static pressure (in.w.g.) } \\
Q & =\text { airflow }(\mathrm{cfm}) \\
N_{\text {test }} & =\text { motor speed at the test speed (rpm) } \\
\mathrm{C}_{\mathrm{p},}, \mathrm{C}_{\mathrm{p} 1}, \mathrm{C}_{\mathrm{p} 2}, \mathrm{C}_{\mathrm{p} 3} & =\text { empirical coefficients }
\end{array}
$$

$$
H\left(Q, N_{\text {test }}\right)=c_{h 0}+c_{h 1} \cdot\left(\frac{Q}{1000}\right)+c_{h 2} \cdot\left(\frac{Q}{1000}\right)^{2}+c_{h 3} \cdot\left(\frac{Q}{1000}\right)^{3}+c_{h 4} \cdot\left(\frac{Q}{1000}\right)^{4}
$$

where

$$
\begin{array}{ll}
H_{\text {blower }} & =\text { shaft power }(\mathrm{W}) \\
Q & =\text { airflow }(\mathrm{cfm}) \\
\mathrm{N}_{\text {test }} & =\text { motor speed at the test speed }(\mathrm{rpm}) \\
\mathrm{C}_{\mathrm{h} 0}, \mathrm{C}_{\mathrm{h} 1}, \mathrm{C}_{\mathrm{h} 2}, \mathrm{C}_{\mathrm{h} 3} & =\text { empirical coefficients }
\end{array}
$$




\section{D.2.1 Fan Laws}

Using the relationships between blower speed, airflow, static pressure, and shaft power, DOE determined the fan curves for speeds other than those at which they were tested.

$$
\frac{N_{1}}{N_{2}}=\frac{Q_{1}}{Q_{2}}\left(\frac{N_{1}}{N_{2}}\right)^{2}=\frac{P_{1}}{P_{2}} \quad\left(\frac{N_{1}}{N_{2}}\right)^{3}=\frac{H_{1}}{H_{2}}
$$

where

$$
\begin{array}{ll}
N & =\text { blower speed }(\mathrm{rpm}) \\
Q & =\text { airflow }(\mathrm{cfm}) \\
P & =\text { static pressure (in.w.g.) } \\
H & =\text { shaft power }(\mathrm{W})
\end{array}
$$

Using the blower equations and the fan laws, the blower pressure and shaft power can be determined for any speed and airflow.

$$
\begin{aligned}
& P(Q, N)=P\left(Q, \frac{N_{\text {test }}}{N}\right) \times\left(\frac{N}{N_{\text {test }}}\right)^{2} \\
& H(Q, N)=H\left(Q, \frac{N_{\text {test }}}{N}\right) \times\left(\frac{N}{N_{\text {test }}}\right)^{3}
\end{aligned}
$$

\section{D.2.2 Motor Speed}

The PSC motors used in the baseline furnaces do not operate at constant speed. The difference between actual operating speed and the synchronous speed of an induction motor is referred to as slip. For six pole induction motors, the synchronous speed is $1200 \mathrm{rpm}$. The rated speed of these motors is $1075 \mathrm{rpm}$, so the slip is $125 \mathrm{rpm}$.

$$
S=N_{\text {sync }}-N
$$

For a broad operating range, the slip on induction motors is proportional to the load. For blower motors the load is the shaft power of the blower. ${ }^{3}$

$$
\frac{S_{1}}{S_{2}}=\frac{H_{1}}{H_{2}}
$$

where

$$
\begin{array}{ll}
S & =\operatorname{slip}(\mathrm{rpm}) \\
N & =\text { motor speed }(\mathrm{rpm})
\end{array}
$$




$$
H \quad \text { = shaft power (hp or W) }
$$

\section{D.2.3 System Effect Factor}

The Department assumed that furnaces are designed so the blower motors operate at rated power at the nominal maximum air flow with 0.5 in.w.g. static pressure. Following this assumption, the Department adjusted the speed until the shaft power of the blower (nominal airflow) matched the rated power output of the motor.

Once DOE found the motor speed necessary to produce the nominal airflow through the furnace at 0.5 in.w.g. external static pressure, the SEF was determined as:

$$
S E F=\frac{P_{\text {blower }}\left(Q_{\text {nom }}, N\right)-P_{\text {furn }}\left(Q_{\text {nom }}\right)}{\left(Q_{\text {nom }}\right)^{2}}
$$

\section{D.2.4 Shaft Power}

The shaft power to turn the blower must equal the shaft power produced by the motor, so the previous equation can be written as:

$$
H_{\text {blower }}(Q, N)=H_{\text {motor_rated }} \cdot \frac{\left(N_{\text {synch }}-N\right)}{\left(S_{\text {rated }}\right)}
$$

For any airflow, the speed can be adjusted iteratively until the equation is solved. Once the speed is known, then the external static pressure across the furnace can be calculated as:

$$
P_{\text {furn }}(Q)=P_{\text {blower }}(Q, N)-S E F \cdot Q^{2}
$$

\section{D.2.5 Fan Curves for Generic Model Furnaces}

For each of the four airflow capacities of generic model furnaces, the Department repeated this process for several values of airflow to determine motor speed and external static pressures during cooling operation. The Department fit a polynomial equation of $\mathrm{P}$ as a function of Q through these points to get the fan curve for each airflow capacity of generic model furnaces. The form of the equation is:

$$
P f_{\text {urn }}(Q)=C_{0}+C_{1} \times\left(\frac{Q}{1000}\right)+C_{2} \times\left(\frac{Q}{1000}\right)^{2}+C_{3} \times\left(\frac{Q}{1000}\right)^{3}
$$


To develop equations of static pressure across the furnace for normal heating or low-fire heating operation modes, DOE fit the pressure from the basic model fan curves directly to air flow.

Table D.2.1 Coefficients for Static Pressure as a Function of Airflow

\begin{tabular}{|c|c|c|c|c|}
\hline & $\mathrm{C}_{0}$ & $\mathrm{C}_{1}$ & $\mathrm{C}_{2}$ & $\mathrm{C}_{3}$ \\
\hline \multicolumn{5}{|c|}{ Cooling } \\
\hline 5 ton & 1.916151 & -0.87805 & 0.317813 & -0.11646 \\
\hline 4 ton & 0.631601 & 1.183158 & -0.90841 & 0.073442 \\
\hline 3ton & 0.259783 & 2.2545 & -2.11025 & 0.332181 \\
\hline 2ton & 1.452571 & -1.26789 & 0.41408 & -0.39707 \\
\hline \multicolumn{5}{|c|}{ Single-stage heating or high fire 2-stage heating } \\
\hline 5 ton & 1.6533 & -1.5622 & 1.6788 & -0.7274 \\
\hline 4 ton & 2.7447 & -6.1898 & 7.4999 & -3.1809 \\
\hline 3ton & 0.0778 & 2.8833 & -2.5288 & 0 \\
\hline 2 ton & 0.9753 & 1.0443 & -2.9451 & 0 \\
\hline \multicolumn{5}{|c|}{ Low-fire heating } \\
\hline 5 ton & 0.511338 & 1.356782 & -1.0186 & 0 \\
\hline 4 ton & -0.08841 & 3.268466 & -2.57168 & 0 \\
\hline 3ton & -0.56392 & 5.35246 & -5.04481 & 0 \\
\hline 2ton & 0.861904 & 1.106394 & -3.14531 & 0 \\
\hline
\end{tabular}




\section{REFERENCES}

1. Air Movement and Control Association International Inc., Fans and Systems, in AMCA Publication 201-90. 1990: Arlington Heights, IL.

2. Lau Industries Inc., e-mail from Michael J. Neely, Research and Development Engineer, to Jim Lutz, personal communication. August 29, 2002.

3. Nadel, S., M. Shepard, S. Greenberg, G. Katz, and A. T. d. Almeida, Energy-Efficent Motor Systems: A Handbook on Technology, Program, and Policy Opportunities. In Series on Energy Conservation and Energy Policy, C. Blumstein, Editor. 1992, American Council for an Energy-Efficient Economy: Washington, DC. p. 76-77. 


\section{APPENDIX E: BLOWER FAN CURVES}

\section{TABLE OF CONTENTS}

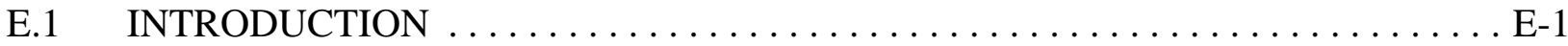

E.2 STATIC PRESSURE . . . . . . . . . . . . . . . . . . . . . . . . . . . . E-4

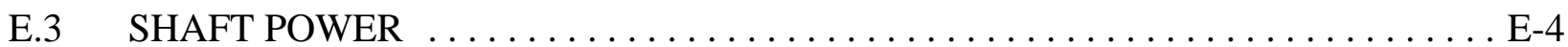

\section{LIST OF TABLES}

Table E.1.1 Models Used For Generic Furnace Blowers $\ldots \ldots \ldots \ldots \ldots \ldots \ldots \ldots$. . . . . . . . .

Table E.2.1 Coefficients to Calculate Pressure for Different Blower Sizes ........... E-4

Table E.3.1 Coefficients to Calculate Shaft Power for Different Blower Sizes . . . . . . . . E-5

\section{LIST OF FIGURES}

Figure E.1 Blower Fan Curves Lau \#DD10-8A $\ldots \ldots \ldots \ldots \ldots \ldots \ldots \ldots \ldots \ldots$ E-2 


\section{APPENDIX E: BLOWER FAN CURVES}

\section{E.1 INTRODUCTION}

Blower manufacturers provide blower fan curves for both pressure and shaft power as functions of airflow. The Department chose four blowers from Lau Industries, a manufacturer that supplies blowers to the furnace industry, to match the four generic model furnace blowers. ${ }^{1}$

The models DOE used for the different generic furnace blowers are listed in Table E.1.1.

Table E.1.1 Models Used For Generic Furnace Blowers

\begin{tabular}{|c|c|c|}
\hline Airflow Capacity & Blower Size & Lau Industries model \\
\hline $800 \mathrm{cfm}$ ( 2 ton) & $9 \times 8$ & DD9-8A \\
\hline $1200 \mathrm{cfm}(3$ ton $)$ & $10 \times 8$ & DD10-8A \\
\hline $1600 \mathrm{cfm}(4$ ton $)$ & $10 \times 10$ & DD10-10A \\
\hline $2000 \mathrm{cfm}$ (5 ton) & $11 \times 10$ & DD11-10AT \\
\hline
\end{tabular}

Pressure and shaft power curves of these blowers are available in a fan selection software from Lau Industries. ${ }^{2}$ Figure E.1 - E.1 shows the curves for these blowers. The Department fit polynomial equations of air flow to the static pressure and shaft power curves of these blowers. Knowing the equations permits the Department to calculate static pressure and shaft power at any airflow rate. 


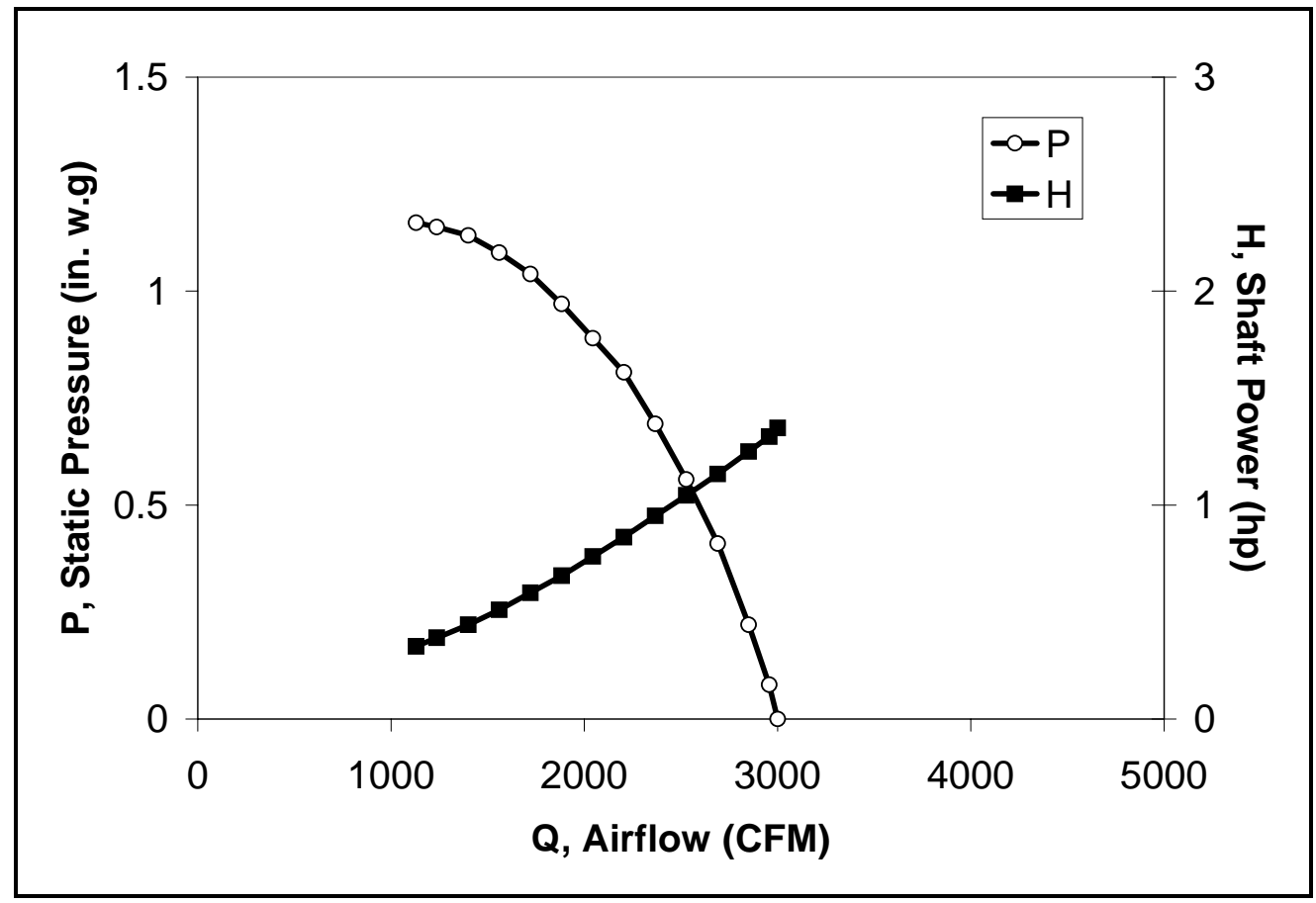

Figure E.1 Blower Fan Curves Lau \#DD10-8A 
INSERT OTHER FIGURES FROM TSD FOLDER FILE 


\section{E.2 STATIC PRESSURE}

The coefficients for the polynomial equation for static pressure rise across the blower as a function of airflow are shown in Table E.2.1. The speeds at which they were tested are included in the table as well. The coefficients vary depending on blower size. The equation used to fit static pressure is:

$$
P(Q)=c 0+c 1 *(Q / 1000)+c 2 *(Q / 1000)^{\wedge} 2+c 3 *(Q / 1000) \wedge 3+c 4 *(Q / 1000)^{\wedge} 4
$$

where

$$
\begin{array}{ll}
\mathrm{Q} & =\text { airflow }(\mathrm{cfm}) \\
\mathrm{P} & =\text { static pressure (in.w.g.) } \\
\mathrm{c} 0-\mathrm{c} 4 & =\text { coefficients }
\end{array}
$$

Table E.2.1 Coefficients to Calculate Pressure for Different Blower Sizes

\begin{tabular}{|c|c|c|c|c|c|c|}
\hline Blower Size & Speed & c0 & c1 & c2 & c3 & c4 \\
\hline $11 \times 10^{*}$ & 1055 & 2.816408 & -14.45755 & 50.06729 & -79.1925 & 57.93131 \\
\hline $10 \times 10$ & 1020 & 0.571842 & 0.952433 & -0.40526 & 0.027687 & 0 \\
\hline $10 \times 8$ & 1044 & 0.05092 & 2.51260 & -1.96989 & 0.64310 & -0.08909 \\
\hline $9 \times 8$ & 1084 & 1.25829 & -1.09850 & 1.17555 & -0.56167 & 0.06693 \\
\hline
\end{tabular}

*For this blower size, the coefficient Q was divided by 4000, not 1000 as shown in the equation.

\section{E.3 SHAFT POWER}

Shaft power is the mechanical power input to the blower. It is the power required to rotate the blower wheel at the rated speed under the rated static pressure and airflow conditions.

The Department determined shaft power using a second-order polynomial equation. The coefficients vary depending on blower size. Tables E.3.1 shows the different blower sizes and their corresponding coefficients that DOE used to determine shaft power.

$$
H(Q)=h 0+h 1 *(Q / 1000)+h 2 *(Q / 1000)^{\wedge} 2
$$

where

$$
\begin{array}{ll}
\mathrm{Q} & =\text { airflow }(\mathrm{cfm}) \\
\mathrm{H} & =\text { shaft power }(\mathrm{hp}) \\
\text { h0-h2 } & =\text { coefficients }
\end{array}
$$


Table E.3.1 Coefficients to Calculate Shaft Power for Different Blower Sizes

\begin{tabular}{|c|c|c|c|c|}
\hline Blower size & Speed & h0 & h1 & h2 \\
\hline $11 \times 10$ & 1055 & 0.02424 & 0.209691 & 0.073447 \\
\hline $10 \times 10$ & 1020 & 0.052032 & 0.195255 & 0.072613 \\
\hline $10 \times 8$ & 1044 & 0.012244 & 0.187546 & 0.086849 \\
\hline $9 \times 8$ & 1084 & 0.044483 & 0.100756 & 0.108843 \\
\hline
\end{tabular}




\section{REFERENCES}

1. Lau Industries Inc., e-mail from Michael J. Neely, Research and Development Engineer, to Jim Lutz, personal communication. August 29, 2002.

2. $\quad$ Lau Industries, Whirl Wind IV, Version 4.0, Fan Application Software. 2000. http://www.lau-ind.com/whirlwind.htm 


\section{APPENDIX F: OVERALL AIR MOVING EFFICIENCY}

\section{TABLE OF CONTENTS}

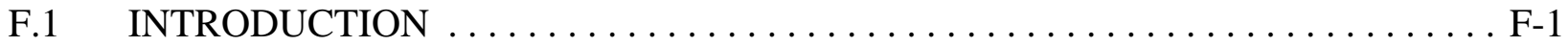

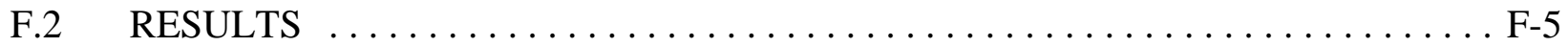

\section{LIST OF TABLES}

Table F.2.1 Coefficients for Overall Air Moving Efficiency of Non-Condensing Generic Model Furnaces ........................ F.1-5

Table F.2.2 Coefficients for Overall Air Moving Efficiency of Condensing

Generic Model Furnaces . . . . . . . . . . . . . . . . . . . . . . . . F.1-5

\section{LIST OF FIGURES}

Figure F.1 Overall Air Moving Efficiency (non-condensing, cooling mode) . . . . . . . F.1-2

Figure F.2 Overall Air Moving Efficiency (non-condensing, low-fire mode) . . . . . . F.1-2

Figure F.3 Overall Air Moving Efficiency (condensing, low-fire mode) .......... F.1-3

Figure F.4 Overall Air Moving Efficiency (non-condensing, heating mode) . . . . . . . F.1-3

Figure F.5 Overall Air Moving Efficiency (condensing, cooling mode) . . . . . . . . F.1-4

Figure F.6 Overall Air Moving Efficiency (condensing, heating mode) $\ldots . \ldots \ldots \ldots$ F.1-4 


\section{APPENDIX F: OVERALL AIR MOVING EFFICIENCY}

\section{F.1 INTRODUCTION}

The overall air moving efficiency is a variable in the calculation of blower motor electricity consumption. The overall air moving efficiency is a ratio of the air power divided by the electric power used by the blower motor. Air power is the power embodied in the air due to its motion and pressure increase. Air power at any operating condition can be calculated for any furnace from pressure, airflow, and supply air outlet area.

In addition to the pressure and airflow data that are available for all furnace models, one manufacturer reports fan motor electricity consumption as well. ${ }^{1,2,3,4,5,6}$ The model series used for these calculations are Lenox G23 and G40 for non-condensing furnaces and Lenox 90UGF, G26Q, and GHR26Q for condensing furnaces. For these models, we calculated air power and overall efficiency for each point in the fan operating tables for each of the models.

The relationships between air power and overall efficiency are only valid for these particular furnace models and vary by airflow capacity. To generalize the relationship of overall air moving efficiency to airflow in order to calculate efficiency for any furnace type, we transformed airflow to a percentage of airflow at free flow. Free flow signifies no pressure difference or drop. The free flow percentage transformation allowed all of the curves to be plotted together independently of cfm measurement. Figures F.1.1 through F.1.6 show the overall air moving efficiency as a function of airflow, where airflow is indicated as fraction of free flow. 


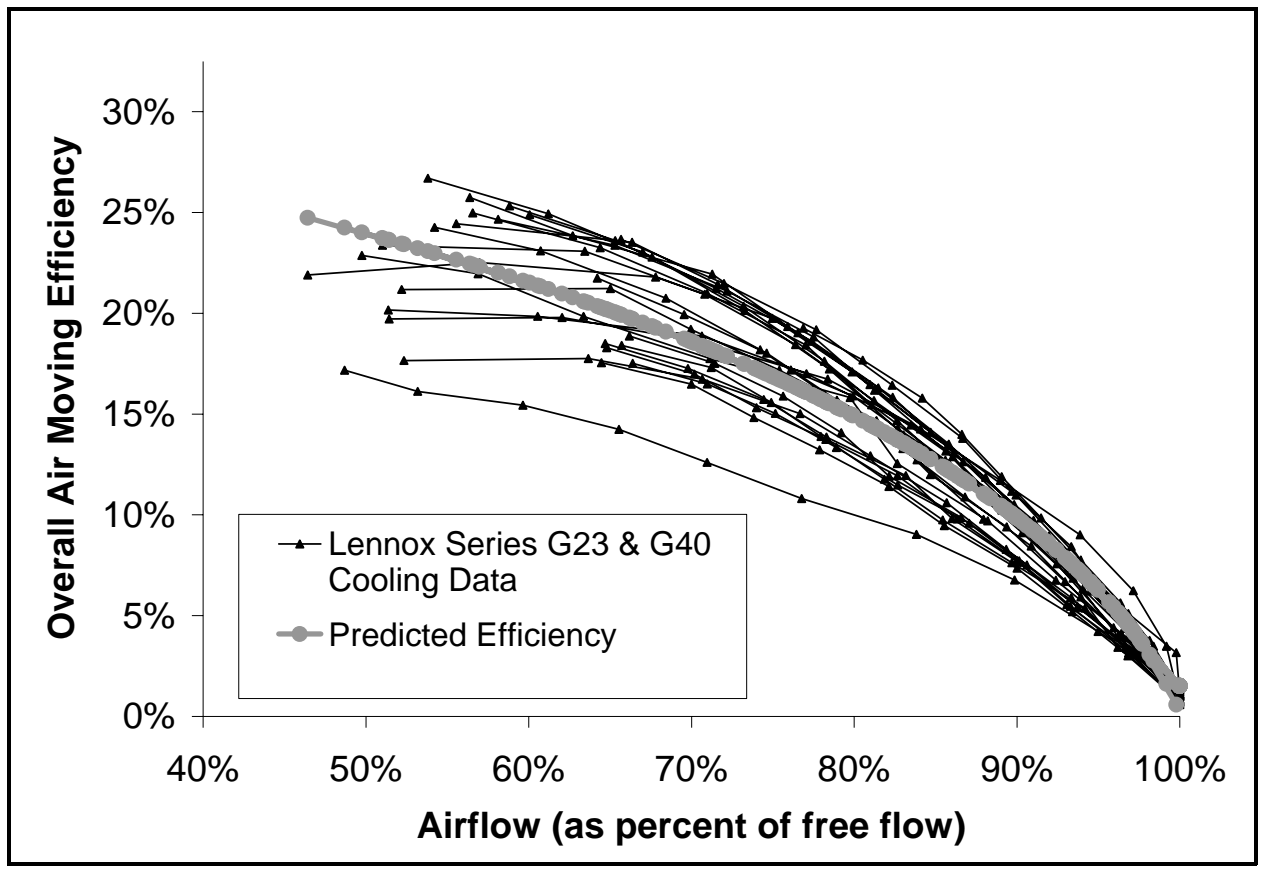

Figure F.1 Overall Air Moving Efficiency (non-condensing, cooling mode)

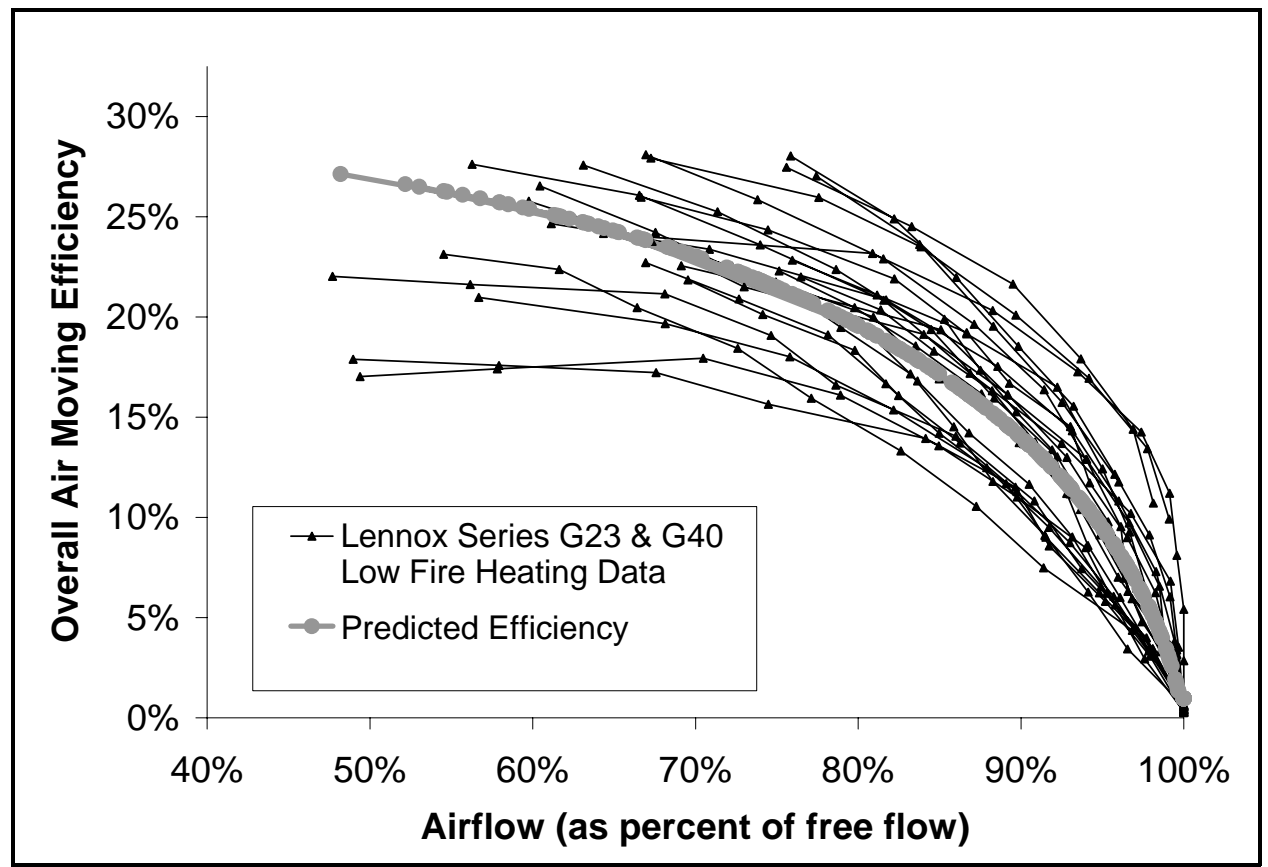

Figure F.2 Overall Air Moving Efficiency (non-condensing, low-fire mode) 


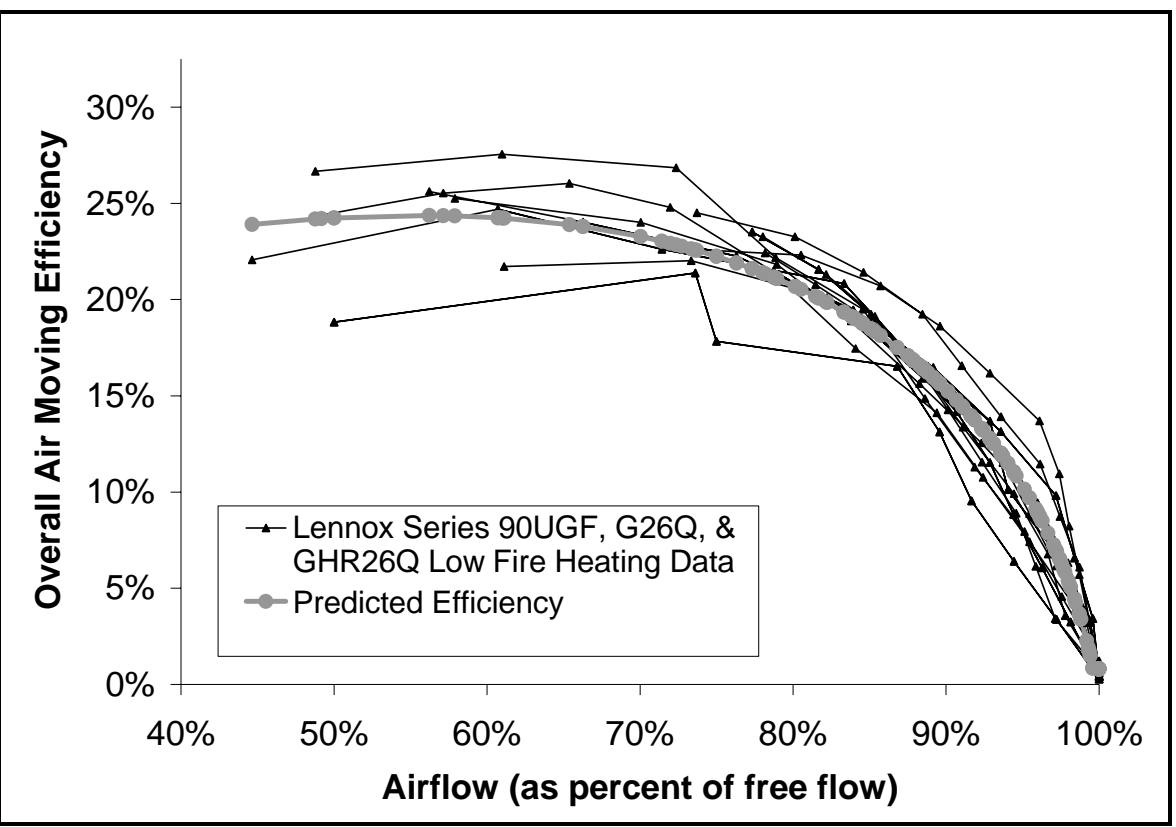

Figure F.3 Overall Air Moving Efficiency (condensing, low-fire mode)

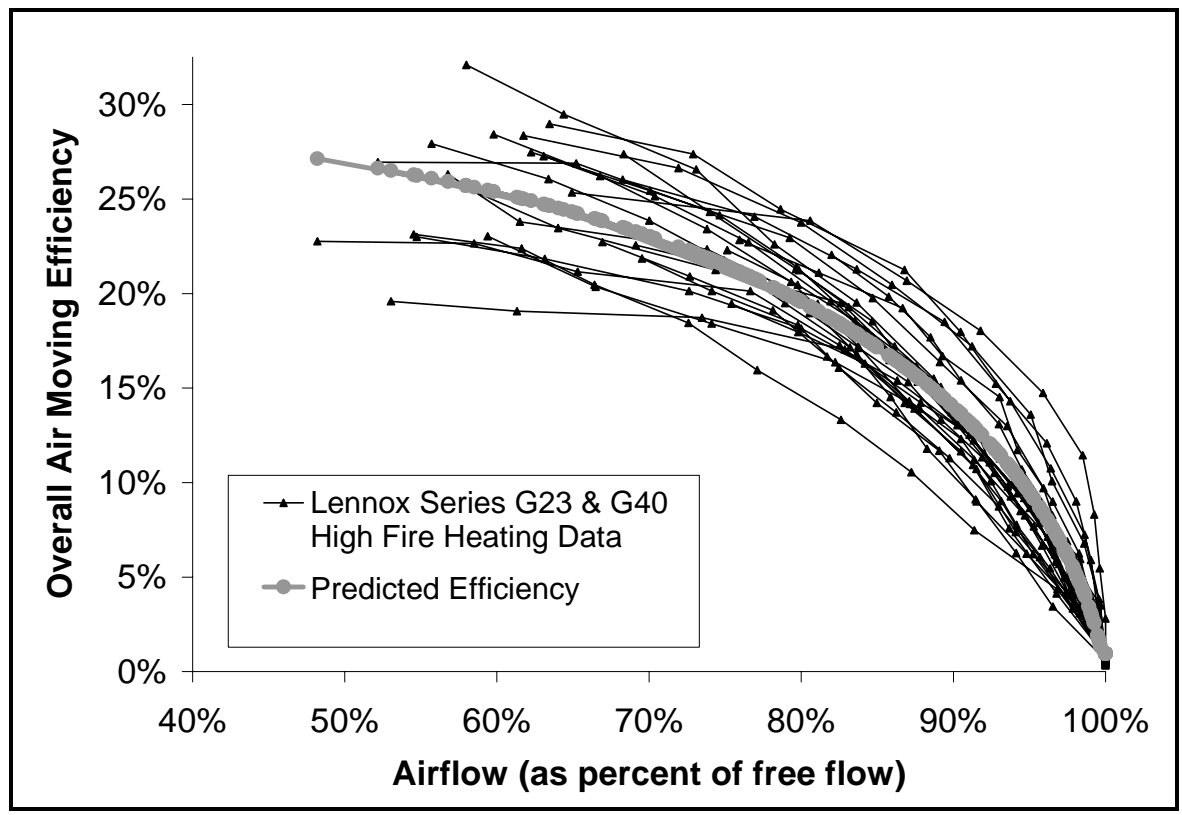

Figure F.4 Overall Air Moving Efficiency (non-condensing, heating mode) 


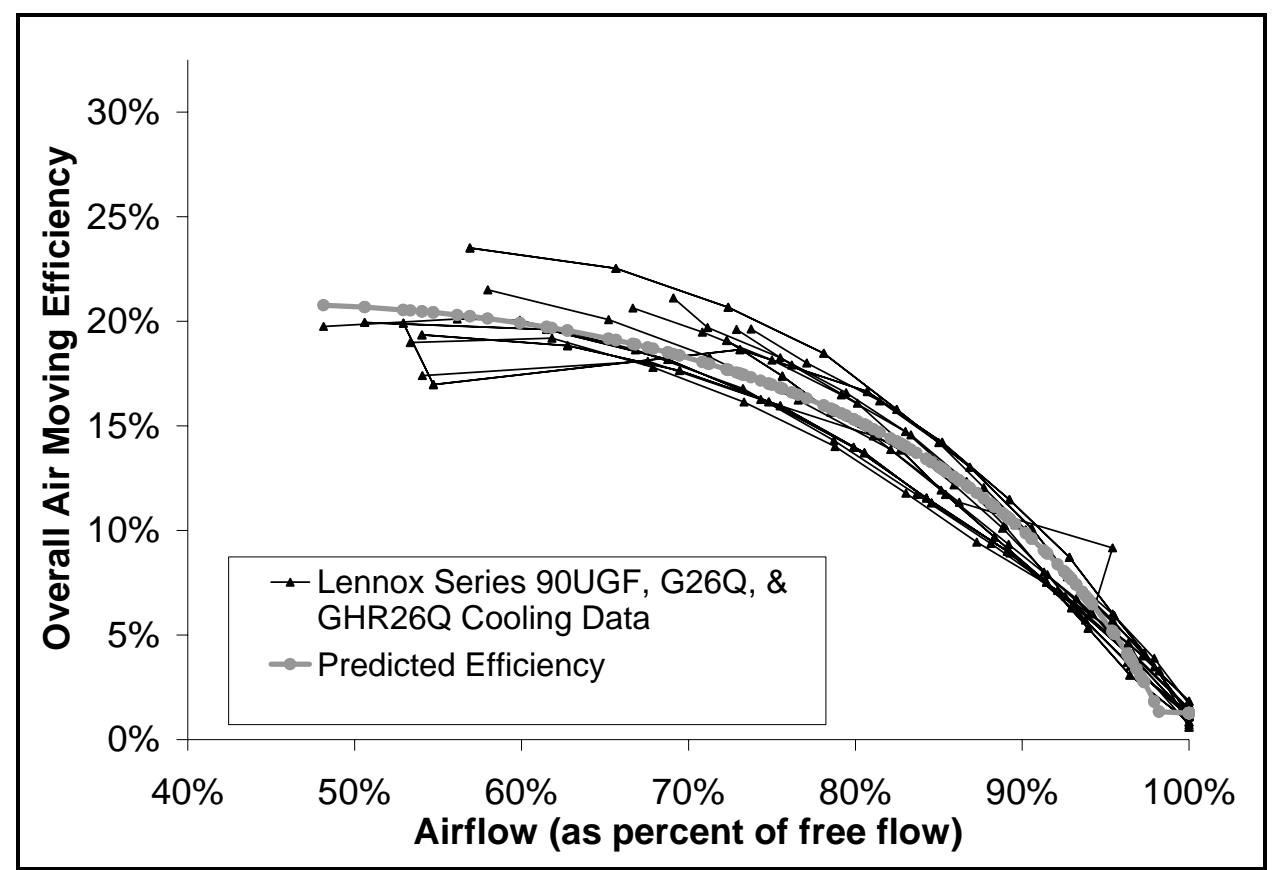

Figure F.5 Overall Air Moving Efficiency (condensing, cooling mode)

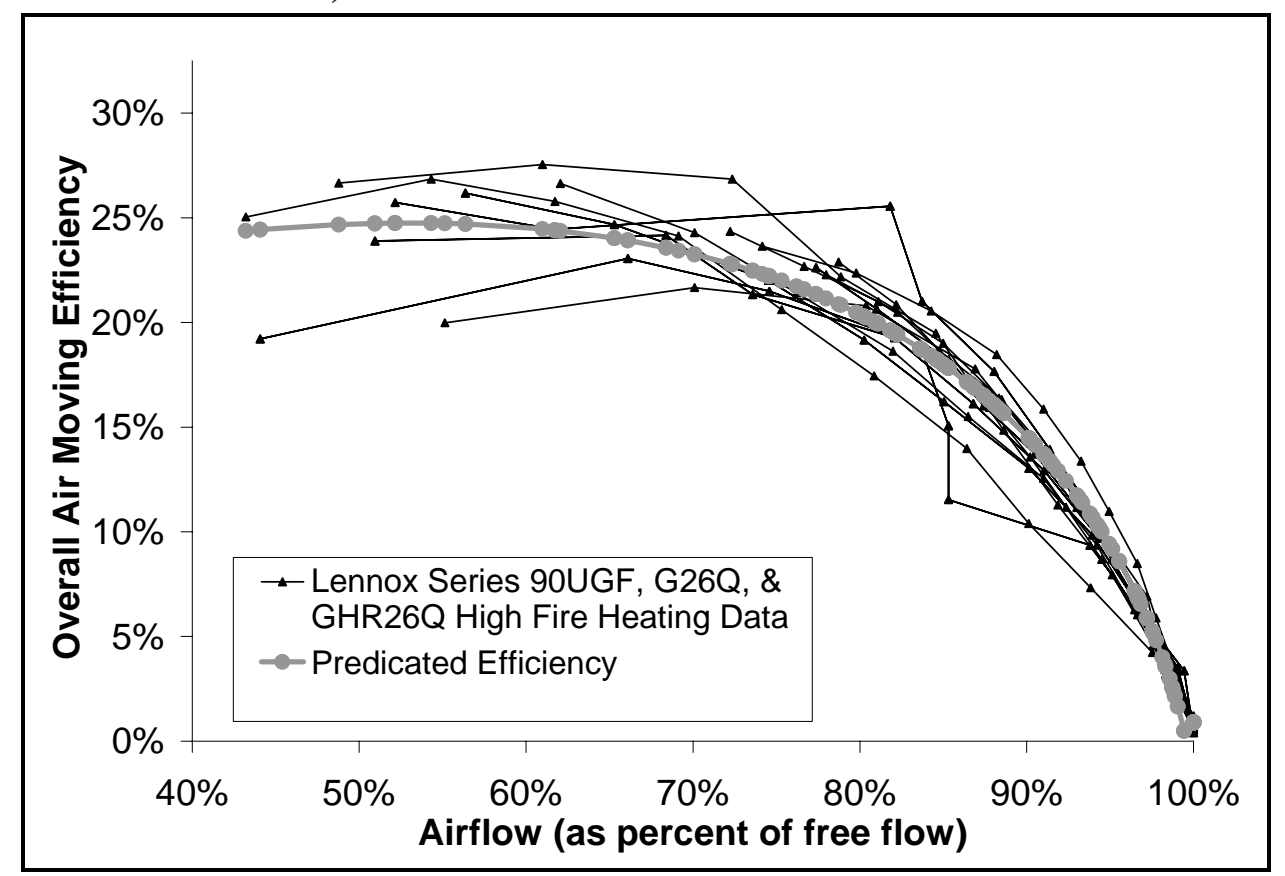

Figure F.6 Overall Air Moving Efficiency (condensing, heating mode) 
Also shown in each figure is a single curve that best fits the other curves in each plot. We fit these curves to an equation of overall efficiency as a function of the ratio of airflow to free airflow. The form of the equation was selected to match the general trends of the overall efficiency curves of the specific models. We found the best fit between the data points from the manufacturers' literature and the equation by adjusting the coefficients to minimize the rootmean-square error in overall efficiency.

$$
\eta_{\text {overall }}=C_{0}+c_{1} \times\left(1-Q_{0}\right)+c_{2} \times\left(1-Q_{0}\right)^{(1 / 2)}+c_{3} \times\left(1-Q_{0}\right)^{(1 / 3)}
$$

where

$$
\begin{array}{ll}
\eta_{\text {overall }} & =\text { overall air moving efficiency } \\
Q_{0} & =\text { ratio of airflow to free flow } \\
C_{0}, C_{1}, C_{2}, C_{3} & =\text { empirically determined coefficients }
\end{array}
$$

\section{F.2 RESULTS}

We calculated the results separately for condensing and non-condensing furnaces, and for each model. The coefficients for the six equations are shown in Tables F.2.1 and F.2.2.

Table F.2.1 Coefficients for Overall Air Moving Efficiency of Non-Condensing Generic Model Furnaces

\begin{tabular}{|c|c|c|c|}
\hline & Cooling & Heating & Low-Fire \\
\hline Coef() & 0.015169 & .0096357 & 0.010040 \\
\hline Coef1 & -0.21144 & -0.49263 & -0.75554 \\
\hline Coef2 & 0.91056 & 1.1948 & 1.4069 \\
\hline Coef3 & -0.39518 & -0.42712 & -0.49662 \\
\hline
\end{tabular}

Table F.2.2 Coefficients for Overall Air Moving Efficiency of Condensing Generic Model Furnaces

\begin{tabular}{|c|c|c|c|}
\hline & Cooling & Heating & Low-Fire \\
\hline Coef() & 0.012659 & 0.0090140 & 0.0079380 \\
\hline Coef1 & -0.74379 & -0.94689 & -0.90500 \\
\hline Coef2 & 1.7392 & 1.8971 & 1.7061 \\
\hline Coef3 & -0.83602 & -0.79362 & -0.65437 \\
\hline
\end{tabular}




\section{REFERENCES}

1. Lennox Industries Inc., Lennox Engineering Data: G26 (Elite 90 Series Upflow Gas Furnace), Bulletin \#210027, 1998. Lennox Industries Inc. (May).

2. Lennox Industries Inc., Lennox Engineering Data: GHR26 (Elite 90 Series Horizontal/Downflow Gas Furnace) Bulletin \# 210093, 1998. Lennox Industries, Inc. (May).

3. Lennox Industries Inc., Lennox Industries Engineering Data: 90UGF (Elite 90-S Upflow Gas Furnace) Bulletin \#210171., 1997. Lennox Industries Inc. (April).

4. Lennox Industries Inc., Lennox Engineering Data: G23 (Elite 80 Upflow Gas Furnace) Bulletin \#210026, 1998. Lennox Industries Inc. (Posted September 1998.) (September).

5. Lennox Industries Inc., Lennox Engineering Data: G40DF (Merit Series Downflow Gas Furnace) Bulletin No. 210320., 2002. Lennox Industries, Inc. (Last accessed June 2002, 2002). <http://www.lennoxcommercial.com/tech_pdf/ehb_g40df_0206.pdf>

6. Lennox Industries Inc., Lennox Engineering Data: G40DF (Merit Series Upflow/Horizontal Gas Furnace) Bulletin No. 210320., 2002. Lennox Industries, Inc. (Last accessed June 2002, 2002).

<http://www.lennoxcommercial.com/tech_pdf/ehb_g40df_0206.pdf> 


\section{APPENDIX G: POWER CONSUMPTION OF ECM BLOWER MOTORS}

\section{TABLE OF CONTENTS}

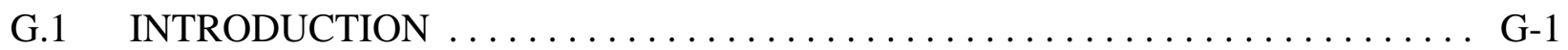

G.2 BLOWER SPEED AND SHAFT POWER $\ldots \ldots \ldots \ldots \ldots \ldots \ldots \ldots \ldots \ldots$ G-1

G.3 DEVELOPMENT OF EFFICIENCY EQUATION $\ldots \ldots \ldots \ldots \ldots \ldots \ldots \ldots$ G-3

G.4 BLOWER MOTOR POWER CONSUMPTION $\ldots \ldots \ldots \ldots \ldots \ldots \ldots \ldots \ldots$ G-10

\section{LIST OF TABLES}

Table G.2.1 Coefficients for Blower Speed Equation $\ldots \ldots \ldots \ldots \ldots \ldots \ldots \ldots$ G-2

Table G.2.2 Coefficients for Blower Shaft Power Equation ................ G-3

Table G.3.1 Coefficients for Equation of $\mathrm{Y}$ at 76\% Efficiency as a Function of X . . . . . G-7

Table G.3.2 Coefficients for Equation of Logistic Transform of Motor Efficiency ..... G-10

\section{LIST OF FIGURES}

Figure G.1 Iso-Efficiency Lines for GE ECM $2.3 \ldots \ldots \ldots \ldots \ldots \ldots \ldots \ldots$ G-4

Figure G.2 Plot of Iso-Efficiency Lines Against Speed and Shaft Power . . . . . . . . G-5

Figure G.3 Plot of Rotated Iso-Efficiency Lines ....................... G-6

Figure G.4 Residuals of Y After Subtracting Predicted 76\% Efficiency Y Values ...... . G-8

Figure G.5 Fit of Transformed Efficiency to Difference between $\mathrm{Y}$ and $76 \%$

Efficiency $Y$ Values ............................ G-9

Figure G.1 Comparison of Reported to Estimated Blower Motor Input Power . . . . . . G-11 


\section{APPENDIX G: POWER CONSUMPTION OF ECM BLOWER MOTORS}

\section{G.1 INTRODUCTION}

For the electronically commutated motor (ECM) design option, we calculated power consumption of blower motors as a function of furnace static pressure. We developed a series of equations to first calculate the blower speed and shaft power from the furnace static pressure. Using the values for shaft power and blower speed, we developed a second series of equations to calculate the blower motor efficiency. Building on the first and second series of equations, we then calculated the blower motor power consumption from the efficiency and shaft power.

\section{G.2 BLOWER SPEED AND SHAFT POWER}

This section explains how we determined blower speed and shaft power from the furnace static pressure.

For furnaces with ECM motors and standard forward-curved impellors in the blower, the airflow and static pressure at operating conditions are determined from the intersection of the fan curve of the furnace and the system curve of the ducts. Furnaces with these motors are programmed to provide a constant airflow regardless of static pressure. Thus, the fan curves for these furnaces are a vertical line of constant airflow.

We calculated the furnace static pressure at the nominal air flow for each of the virtual model furnaces for a range of blower speeds. (See Appendix D, Furnace Fan Curves, for an explanation of the furnace static pressure equation.)

$$
P_{\text {furn }}=P_{\text {blower }}(Q, N)-S E F \times Q^{2}
$$

where

$$
\begin{array}{lll}
P_{\text {furn }} & = & \text { furnace static pressure (in.w.g.), } \\
P_{\text {blower }} & = & \text { static pressure across blower alone (in.w.g.), } \\
Q & = & \text { airflow (cfm), } \\
N & = & \text { motor speed (rpm), and } \\
\text { SEF } & = & \text { system effect factor. }
\end{array}
$$

With the calculated static pressures, we developed an equation for blower speed as a function of static pressure at the nominal airflows of the generic model furnaces.

$$
N\left(P_{\text {furn }}\right)=C_{0}+C_{1} \times P_{\text {furn }}+C_{2} \times P_{\text {furn }}{ }^{2}+C_{3} \times P_{\text {furn }}{ }^{3}
$$


where

$$
\begin{aligned}
& N \quad=\quad \text { motor speed (rpm), } \\
& { }^{P} \text { furn } \quad=\quad \text { furnace static pressure (in.w.g.), and } \\
& C_{0}, C_{1}, C_{2}, C_{3}=\quad \text { empirical coefficients from curve fitting. }
\end{aligned}
$$

The coefficients for the equations of blower speed as a function of furnace static pressure for generic furnaces with ECM motors and forward-curved impellors are shown in Table G.2.1.

Table G.2.1 Coefficients for Blower Speed Equation

\begin{tabular}{|ccrrrc|}
\hline & $\mathbf{Q}$ & $\mathbf{C}_{\mathbf{0}}$ & \multicolumn{1}{c}{$\mathbf{C}_{\mathbf{1}}$} & $\mathbf{C}_{\mathbf{2}}$ & $\mathbf{C}_{\mathbf{3}}$ \\
\hline Cooling & & & & & \\
2-ton & 800 & 758.510902 & 818.311142 & -314.27103 & 88.0707484 \\
3-ton & 1200 & 749.383575 & 539.726313 & -113.76913 & 32.9063052 \\
4-ton & 1600 & 746.778132 & 462.47066 & -48.570713 & 0 \\
5-ton & 2000 & 853.498286 & 446.471489 & -43.055706 & 0 \\
\hline High Fire & & & & & \\
2-ton & 640 & 608.29206 & 994.40398 & -510.6498 & 173.2131 \\
3-ton & 960 & 600.52032 & 658.79742 & -172.3176 & 59.047199 \\
4-ton & 1280 & 598.34369 & 567.4097 & -77.75611 & 0 \\
5-ton & 1600 & 682.74296 & 558.79107 & -85.34107 & 0 \\
\hline Low Fire & & & & & \\
2-ton & 533.3 & 506.0368 & 1164.7986 & -727.0327 & 265.41284 \\
3-ton & 800.0 & 505.36184 & 716.89594 & -95.81477 & 0 \\
4-ton & 1066.7 & 500.31672 & 662.7684 & -106.8632 & 0 \\
5-ton & 1333.3 & 569.14764 & 666.9781 & -141.5275 & 0 \\
\hline
\end{tabular}

For the same air flow and speeds that were used to evaluate furnace static pressure, DOE evaluated the blower shaft power using the equation developed in Appendix E, Blower Fan Curves. From this evaluation, we developed an equation for blower shaft power as a function of furnace static pressure at the nominal airflows of the generic model furnaces.

$$
H\left(P_{\text {furn }}\right)=C_{0}+C_{1} \times P_{\text {furn }}+C_{2} \times P_{\text {furn }}{ }^{2}+C_{3} \times P_{\text {furn }}{ }^{3}
$$

where

$$
\begin{array}{ll}
H_{\text {furn }} & =\text { blower shaft power (which is also the motor output power) }(\mathrm{W}), \\
C_{0}, C_{1}, C_{2}, C_{3} & =\text { furnace static pressure (in.w.g.), and }
\end{array}
$$


The coefficients for the equations of blower shaft power as a function of furnace static pressure for generic furnaces with ECM motors and forward-curved impellors are shown in Table G.2.2.

Table G.2.2 Coefficients for Blower Shaft Power Equation

\begin{tabular}{|ccrrrr|}
\hline & $\mathbf{Q}$ & $\mathbf{C}_{\mathbf{0}}$ & $\mathbf{C}_{\mathbf{1}}$ & $\mathbf{C}_{\mathbf{2}}$ & $\mathbf{C}_{\mathbf{3}}$ \\
\hline Cooling & & & & & \\
2-ton & 800 & 0.0152708 & 0.050746 & 0.0257333 & -0.005583 \\
3-ton & 1200 & 0.2104571 & 0.2417293 & 0.0078857 & 0.0053584 \\
4-ton & 1600 & 0.323437 & 0.337503 & 0.0327196 & -0.000428 \\
5-ton & 2000 & 0.5250273 & 0.4308035 & 0.0462496 & -0.015896 \\
\hline High Fire & & & & & \\
2-ton & 640 & 0.0077478 & 0.0418898 & 0.0275575 & -0.00666 \\
3-ton & 960 & 0.1078423 & 0.1919758 & 0.0143375 & 0.0067217 \\
4-ton & 1280 & 0.1656094 & 0.2697001 & 0.0420681 & -0.001972 \\
5-ton & 1600 & 0.2687731 & 0.3456568 & 0.0540197 & -0.027583 \\
\hline Low Fire & & & & & \\
2-ton & 533.3 & 0.00452 & 0.0355173 & 0.0293339 & -0.007401 \\
3-ton & 800.0 & 0.0624766 & 0.1584268 & 0.0229145 & 0.0063644 \\
4-ton & 1066.7 & 0.0958492 & 0.2245117 & 0.0514025 & -0.004302 \\
5-ton & 1333.3 & 0.1555447 & 0.2907602 & 0.0517586 & -0.034138 \\
\hline
\end{tabular}

\section{G.3 DEVELOPMENT OF EFFICIENCY EQUATION}

To find motor efficiency from motor speed and shaft power, DOE started with data from a typical ECM motor used regularly by furnace manufacturers, GE ECM 2.3. Figure G.3.1 shows the iso-efficiency lines for the GE ECM 2.3 series motors. ${ }^{1}$ This chart was taken from a brochure published by General Electric and manually converted to 250 data points. 


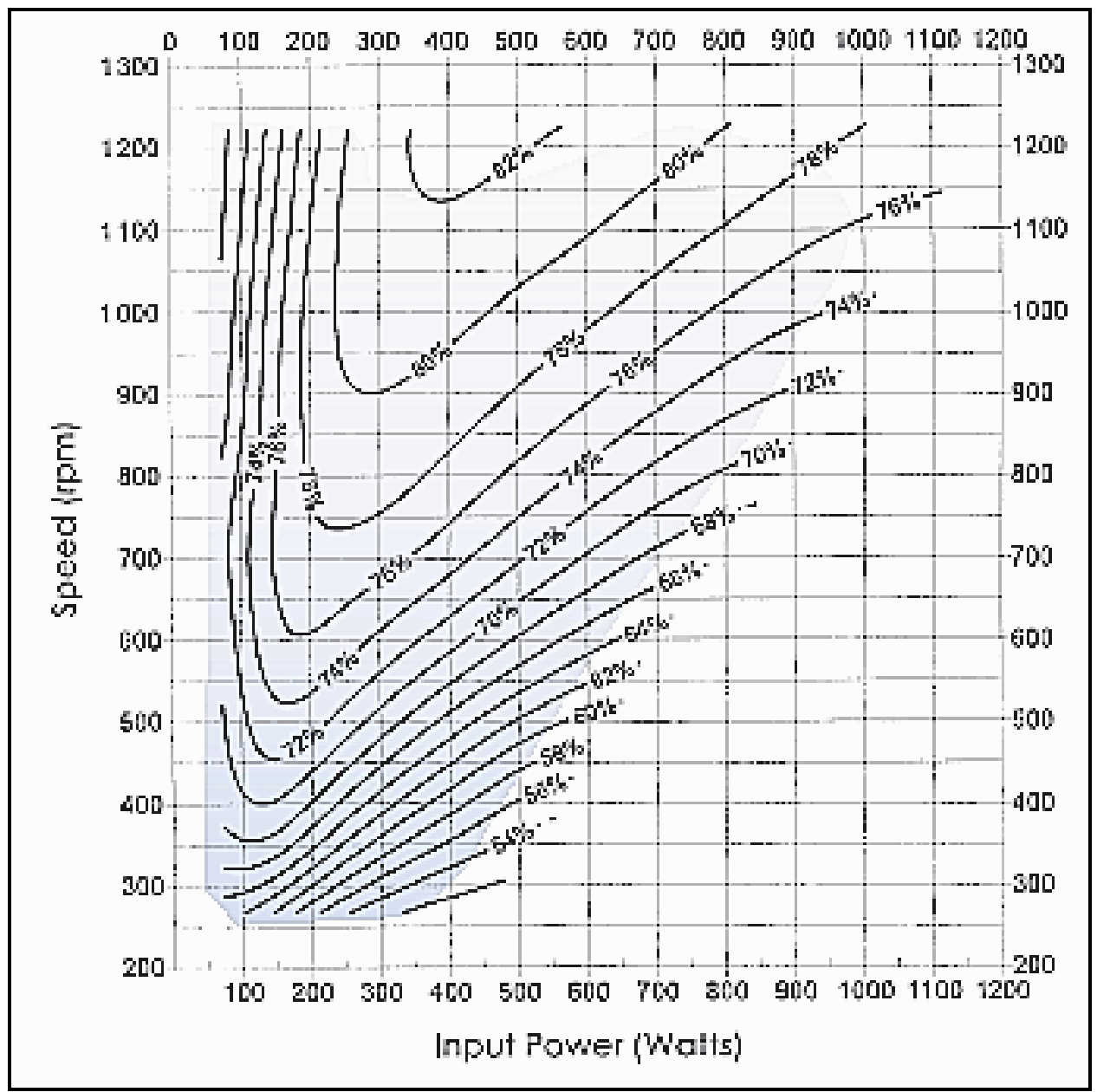

Figure G.1 Iso-Efficiency Lines for GE ECM 2.3

Although input power is given as one of the parameters in this chart, once the data is digitzed, it can be rearranged and input power can be considered as a function of shaft power and motor efficiency. Shaft power is calculated as a product of input power and motor efficiency:

$$
H=B E \times \eta_{\text {motor }}
$$

where

$\begin{array}{lll}H & = & \text { shaft power }(\mathrm{W}), \\ B E & = & \text { input power }(\mathrm{W}), \text { and } \\ \eta_{\text {motor }} & = & \text { motor efficiency. }\end{array}$

A plot of transformed iso-efficiency lines in a speed $(\mathrm{N})$ and shaft power $(\mathrm{H})$ plane is shown in Figure G.3.2 below. 


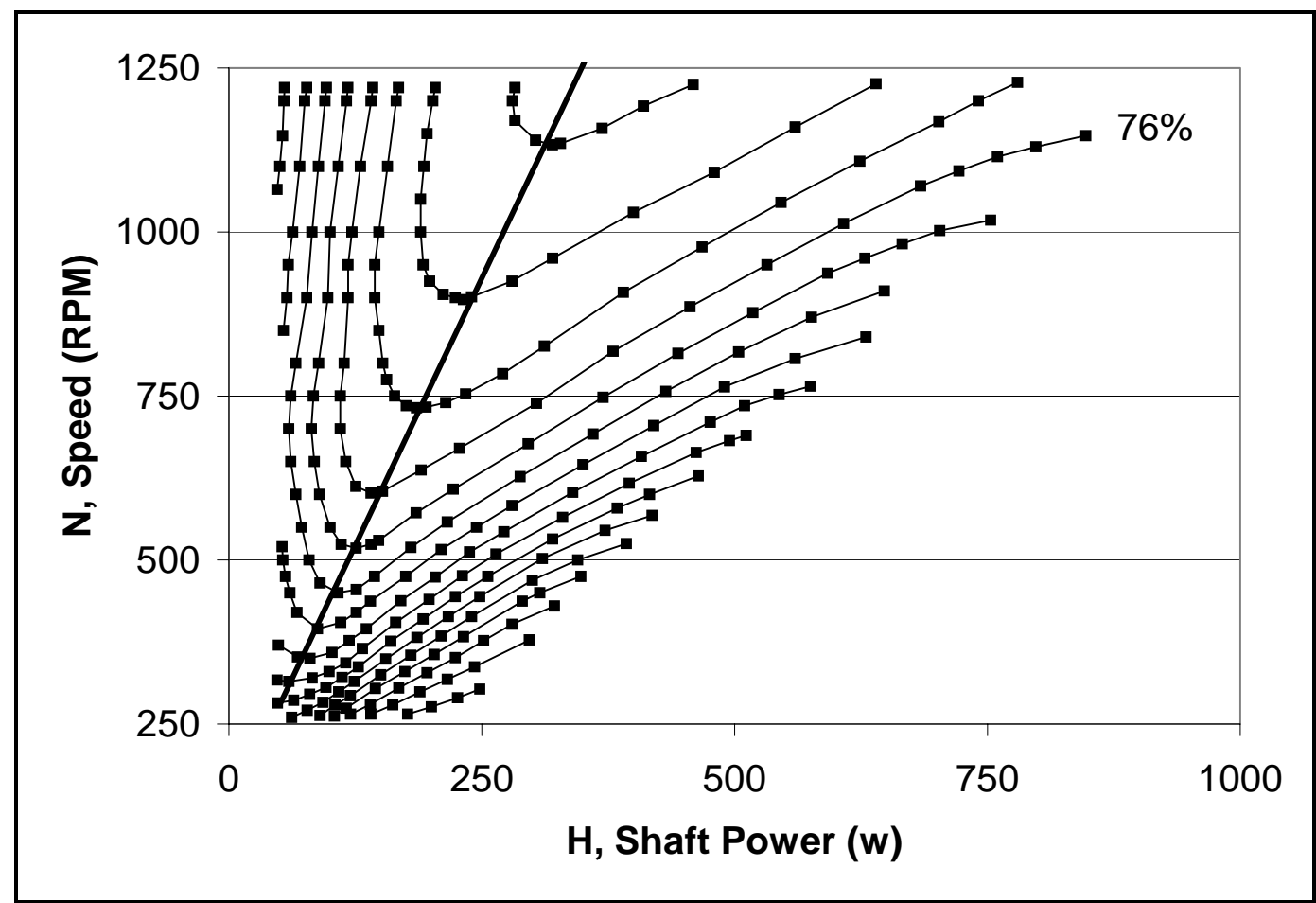

Figure G.2 Plot of Iso-Efficiency Lines Against Speed and Shaft Power

We fit a straight line through the minimum speed points of all iso-efficiency lines. We rotated the axes so that the fit line was vertical by applying the following transformation to every point on the iso-efficiency lines in the plot. The new axes of this plot ( $X$ and $Y$ ) do not have any physical meaning, but are used in the intermediate calculations to calculate efficiency. After this rotation, an equation can be fit to the data to give an equation of $Y$ as a function of $X$ (see Figure G.3.3).

$$
\left[\begin{array}{l}
X \\
Y
\end{array}\right]=\left[\begin{array}{l}
H \\
N
\end{array}\right] \times\left[\begin{array}{cc}
\cos (\theta) & \sin (\theta) \\
-\sin (\theta) & \cos (\theta)
\end{array}\right]
$$

where

$$
\begin{array}{lll}
H & = & \text { shaft power }(\mathrm{W}), \\
N & = & \text { motor speed (rpm), and } \\
\theta & = & 17.09^{\circ}, \text { the angle of rotation. }
\end{array}
$$

The angle of rotation is the difference in degrees between vertical and the slope of the line fit through the minimum speed points on the iso-efficiency lines. 


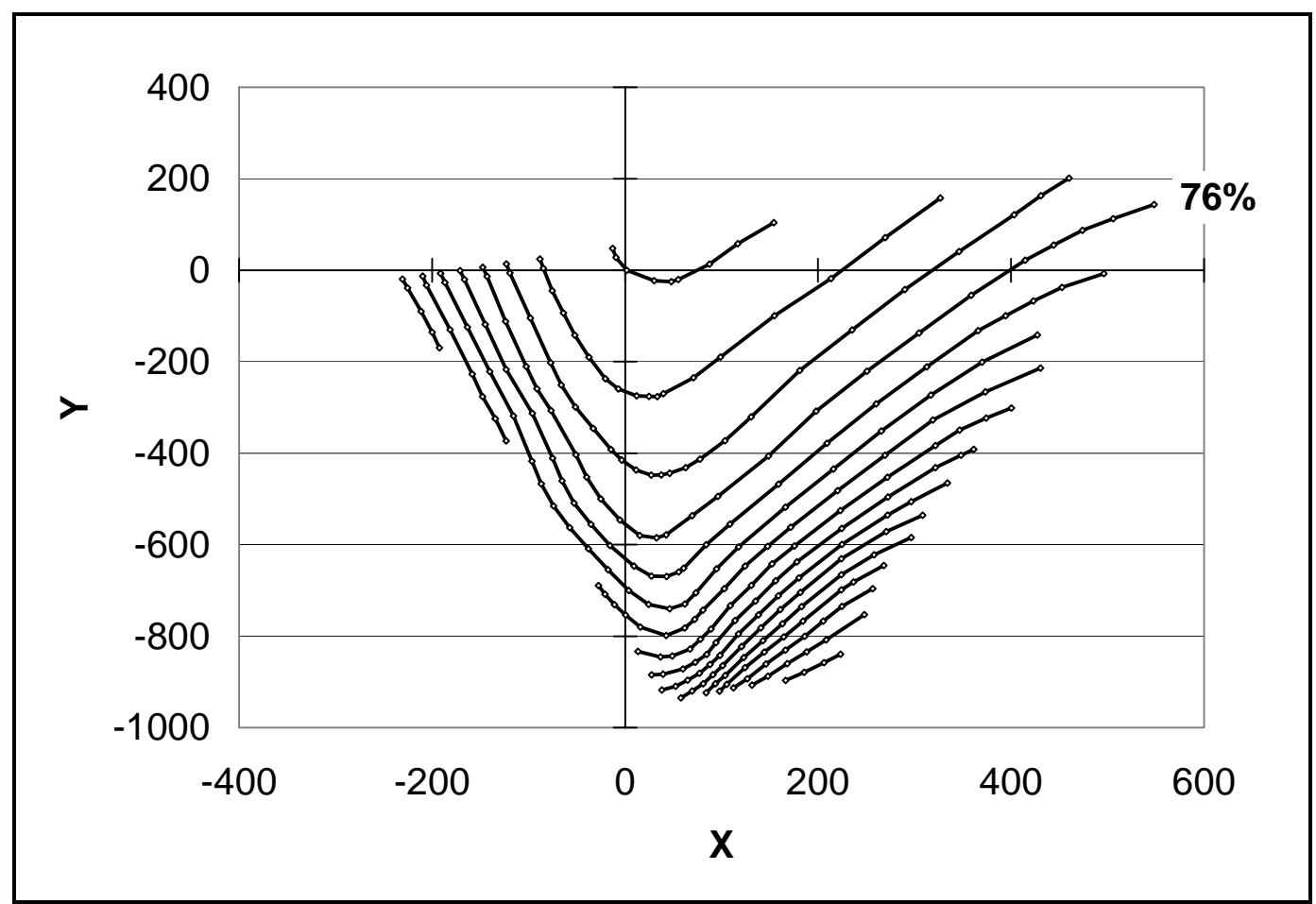

Figure G.3 Plot of Rotated Iso-Efficiency Lines

We fit an equation to the iso-efficiency line at an efficiency of $76 \%$ because this line had the most data points. The form of the equation is:

$$
Y_{76}=\left(C_{0} \times \sqrt{X^{\prime 2}+C_{1}^{2}}\right)-e^{\left(C_{2}+\frac{X^{\prime}}{C_{3}}\right)}
$$

where

$$
\begin{aligned}
\mathrm{Y}_{76} & =Y^{\prime} @ \eta_{\text {motor }}=76 \%, \\
Y^{\prime} & =Y-Y_{\text {trans }}, \text { and } \\
X^{\prime} & =X-X_{\text {trans }} .
\end{aligned}
$$

where

$Y_{76}=$ translated $\mathrm{Y}$ value for $76 \%$ motor efficiency line,

Ytrans $\quad=$ amount $\mathrm{Y}$ value was translated,

$X_{\text {trans }}=$ amount $\mathrm{X}$ value was translated, and

$C_{0}, C_{1}, C_{2}, C_{3}=$ empirical coefficients from curve fitting.

This equation has two main parts. The first part is a hyperbola that is used to fit the left side of the curve. The second part is an exponential curve that has the effect of pulling down the 
right side of the hyperbola to match the data points. All the coefficients and the translation along the $\mathrm{X}$ and $\mathrm{Y}$ axes were selected to give the best possible fit to the data. They are listed in Table G.3.1.

\section{Table G.3.1 Coefficients for Equation of $\mathrm{Y}$ at $76 \%$ Efficiency as a Function of $\mathrm{X}$}

\begin{tabular}{|c|l|}
\hline$X_{\text {trans }}$ & 281.305 \\
\hline$Y_{\text {trans }}$ & 1170.78 \\
\hline$C_{0}$ & 4.066465 \\
\hline$C_{1}$ & 69.497914 \\
\hline$C_{2}$ & 6.732347 \\
\hline$C_{3}$ & 594.895937 \\
\hline
\end{tabular}

The differences in $Y$ between the line at 76\% efficiency and the other iso-efficiency lines is nearly constant for all values of $X$ (See Figure G.3.4.) The plot shows all the points, with the $Y$ value for the $76 \%$ efficiency subtracted.

The efficiency for data points off the $76 \%$ iso-efficiency line can now be calculated as a function of the differences in Y from the 76\% iso-efficiency line. Before doing this, we applied a logistic transform to the efficiency values. Because efficiency is limited by definition to between $0 \%$ and $100 \%$, polynomial fits of efficiency are often done more accurately on a logistic transformation. The equation used for the logistic transform is:

$$
T=\ln \left(\frac{1}{\eta_{\text {motor }}}-1\right)
$$

where

$$
\begin{array}{lll}
T & = & \text { logistic transform of motor efficiency, and } \\
\eta_{\text {motor }} & = & \text { motor efficiency. }
\end{array}
$$

And the difference in $Y$ from the $76 \%$ iso-efficiency line is calculated as:

$$
Y_{76 R}=Y^{\prime}-Y_{76}
$$




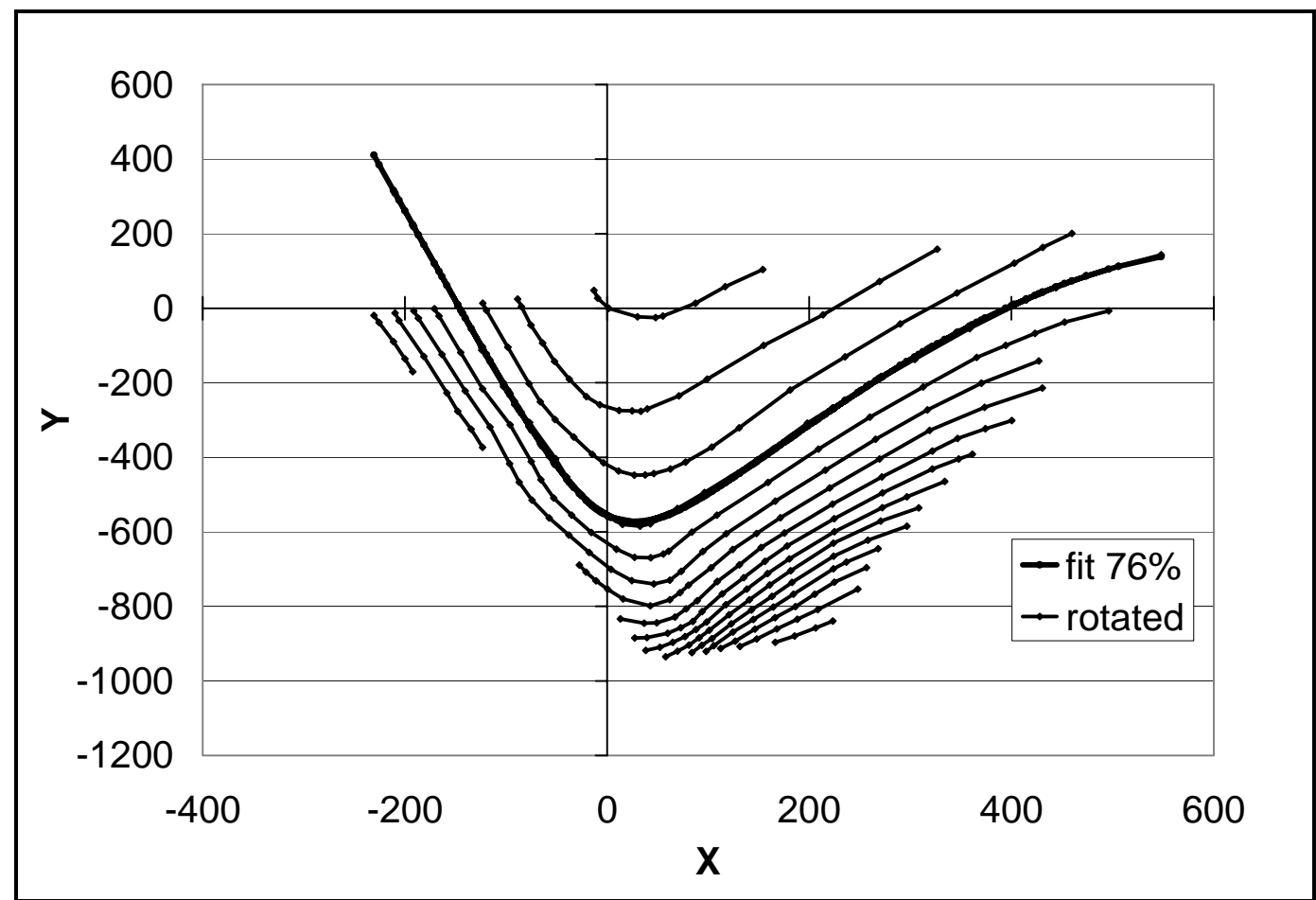

Figure G.4 Residuals of Y After Subtracting Predicted 76\% Efficiency Y Values

where

$Y_{76}=\quad$ translated $Y$ value for $76 \%$ motor efficiency line, and $Y^{\prime}=$ translated $Y$ value.

We fit a polynomial equation of the difference between $Y$ and the $Y$ of the $76 \%$ efficiency line to the logistic transform of the efficiency (shown in Figure G.3.5). 


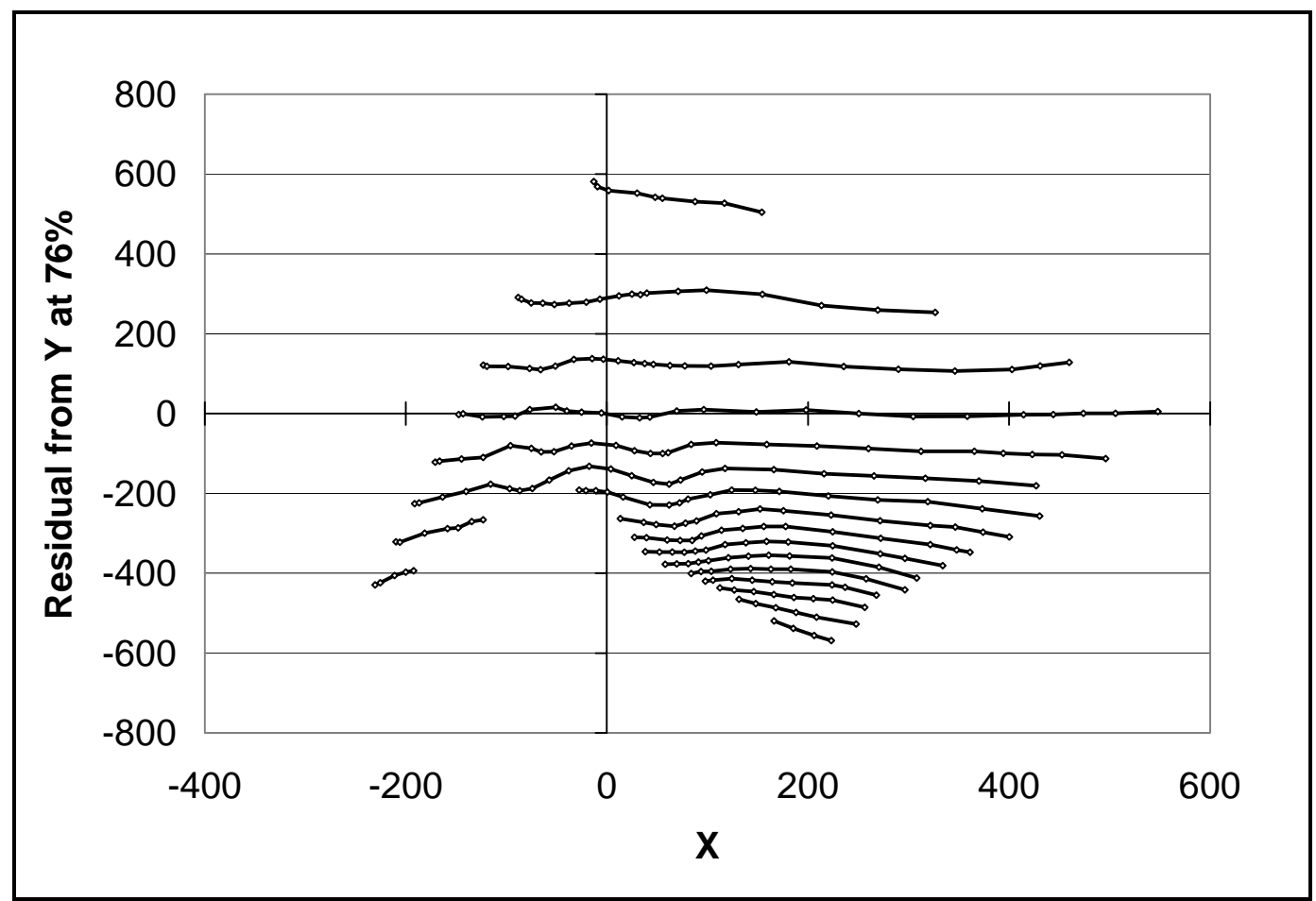

Figure G.5 Fit of Transformed Efficiency to Difference between Y and $76 \%$ Efficiency Y Values

The equation for this fit is:

$$
T=C_{0}+C_{1} \times Y_{76 R}+C_{2} \times Y_{76 R}{ }^{2}+C_{3} \times Y_{76 R}{ }^{3}
$$

where

$T \quad=\quad$ logistic transform of motor efficiency,

$Y_{76 R}=\quad$ difference between $Y^{\prime}$ and $Y^{\prime}$ for the $76 \%$ efficiency line, and $C_{0}, C_{1}, C_{2}, C_{3}=\quad$ empirical coefficients from curve fitting.

The coefficients were selected to give the best possible fit to the data. They are listed in Table G.3.2. 


\section{Table G.3.2 Coefficients for Equation of Logistic Transform of Motor Efficiency}

\begin{tabular}{|l|l|}
\hline$C_{0}$ & -1.156317102 \\
\hline$C_{1}$ & -1.075425258 \\
\hline$C_{2}$ & 1.278606109 \\
\hline$C_{3}$ & -0.947312475. \\
\hline
\end{tabular}

At this point, the efficiency of the motor can be calculated from the transformed efficiency as:

where

$$
\eta_{\text {motor }}=\frac{1}{\left(1+e^{T}\right)}
$$

$$
\begin{array}{lll}
\eta_{\text {motor }} & = & \text { motor efficiency, and } \\
\boldsymbol{T} & = & \text { logistic transform of motor efficiency. }
\end{array}
$$

\section{G.4 BLOWER MOTOR POWER CONSUMPTION}

The electrical power consumption of the ECM blower motor is calculated as:

$$
B E=\frac{H\left(P_{\text {furn }}\right)}{\eta_{\text {motor }}\left(H\left(P_{\text {furn }}\right), N\left(P_{\text {furn }}\right)\right)}
$$

where

$\begin{array}{lll}B E & = & \text { blower motor electrical input power (W), } \\ H & = & \text { shaft power (W), } \\ \eta_{\text {motor }} & = & \text { motor efficiency, } \\ N & = & \text { motor speed (rpm), } \\ P_{\text {furn }} & = & \text { furnace static pressure (in.w.g.), } \\ T & = & \text { logistic transform of motor efficiency. }\end{array}$

A check shows close correlation between the reported and calculated values for $B E$ as seen in Figure G.4.1. The plot compares the motor input power to the motor input power calculated from blower shaft power and motor speed from the digitized data used to develop the equations listed above. 


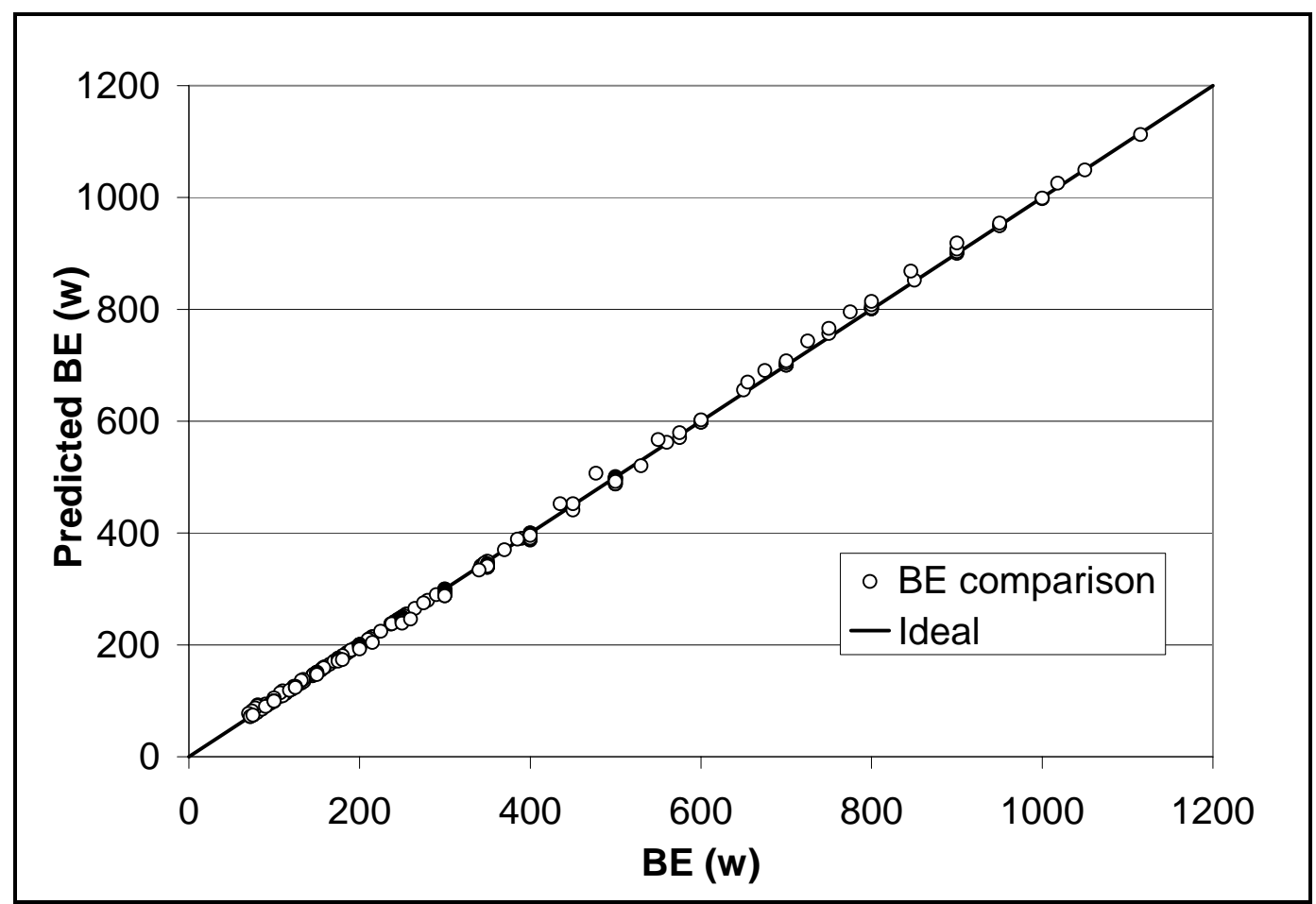

Figure G.1 Comparison of Reported to Estimated Blower Motor Input Power 


\section{REFERENCES}

1. General Electric Company, General Electric Brochure, (Last accessed August 28, 2002). <http://www.geindustrial.com/products/brochures/GET-8068.pdf> 


\section{APPENDIX H: POWER CONSUMPTION OF BC/ECM+ BLOWER MOTORS}

\section{TABLE OF CONTENTS}

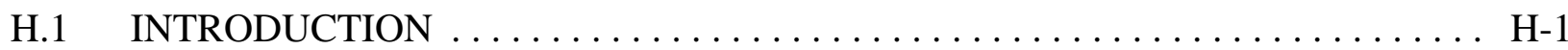

H.2 SHAFT POWER AND STATIC PRESSURE AT CONSTANT SPEED . . . . . . . . H-2

H.3 BLOWER AT OTHER SPEEDS AND AIRFLOWS $\ldots \ldots \ldots \ldots \ldots \ldots \ldots \ldots \ldots$ H-3

H.4 OTHER SIZE BLOWERS $\ldots \ldots \ldots \ldots \ldots \ldots \ldots \ldots \ldots \ldots \ldots \ldots \ldots \ldots . \ldots \ldots$

H.5 SYSTEM EFFECT FACTOR OF BLOWERS IN FURNACES $\ldots \ldots \ldots \ldots \ldots .$. H-5

H.6 BLOWER SPEED AND SHAFT POWER AS FUNCTION OF FURNACE STATIC

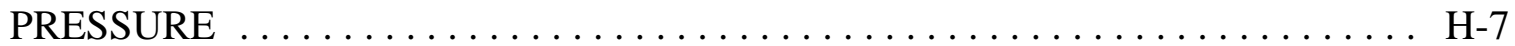

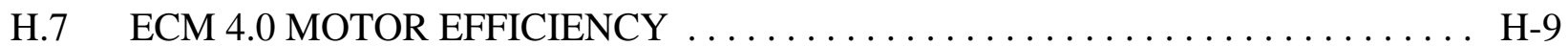

H.8 BC/ECM+ BLOWER MOTOR ELECTRICITY CONSUMPTION $\ldots \ldots \ldots \ldots$ H-10

\section{LIST OF TABLES}

Table H.2.1 Coefficients for Shaft Power and Static Pressure at Constant Speed . . . . H-3

Table H.4.1 Scalars for Airflow and Shaft Power for the Backward-Inclined Blowers $\ldots \ldots \ldots \ldots \ldots \ldots \ldots \ldots \ldots \ldots . \ldots \ldots$ H -4

Table H.5.1 SEF for BC/ECM+ Blowers in Generic Model Furnaces $\ldots \ldots \ldots \ldots$. . H-7

Table H.6.1 Coefficients for Blower Speed Equation $\ldots \ldots \ldots \ldots \ldots \ldots \ldots \ldots \ldots$ H-8

Table H.6.2 Coefficients for Blower Shaft Power Equation $\ldots \ldots \ldots \ldots \ldots \ldots \ldots \ldots$ H-9

\section{LIST OF FIGURES}

Figure H.1 Pressure and Shaft Power versus Airflow at Constant Speed . . . . . . . H-2

Figure H.1 SEF Versus Nominal Airflow for Generic Model Furnaces $\ldots \ldots \ldots \ldots$ H-6

Figure H.1 Efficiencies and Operating Range of Prototype Motor $\ldots \ldots \ldots \ldots$. . H-10 


\section{APPENDIX H: POWER CONSUMPTION OF BC/ECM+ BLOWER MOTORS}

\section{H.1 INTRODUCTION}

General Electric Industrial Systems has developed a prototype backward-inclined blower impellor for use in residential furnace and air handlers. ${ }^{1}$ Backward-inclined blowers have significantly wider blades and must rotate at higher speeds to provide the same static pressure rise as forward-curved blowers of the same size. As part of this project, GE also developed a new motor, ECM 4.0, which is able to drive the new blower.

The Department developed the equations to predict blower motor electrical power consumption for the BC/ECM+ design option based on this prototype.

From a figure of efficiencies and pressures versus airflow of the GE prototype, DOE developed equations for shaft power and static pressure as functions of airflow. These equations, combined with the fan laws, allowed the Department to determine shaft power and static pressure for any speed and airflow for this prototype blower. The Department developed modifications of these equations to estimate the performance of blowers of other sizes to cover generic model furnaces of other airflow capacities.

The GE prototype is designed to provide airflow for a furnace designed to accommodate a 3-ton air conditioner. The Department assumed it would be matched to a furnace designed to have a system effect factor (SEF) giving a static pressure rise across the furnace of 0.5 in.w.c. at an airflow of $1200 \mathrm{cfm}$. The ratio of the SEF for other size furnaces to the SEF of this furnace was assumed to follow the pattern seen in furnaces with forward-curved blowers.

Furnaces with these backward-inclined blowers are intended to operate at constant airflow, regardless of the static pressure. Once the equations based on airflow were developed, the Department applied them to determine the blower speeds required to provide nominal airflow across a range of static pressures. Shaft power was determined at these same operating points to fit equations of blower speed and shaft power as polynomial functions of furnace static pressure.

GE reported the efficiency of the ECM 4.0 at two operating conditions. The two points had almost identical efficiencies. The points roughly span the intended operating range of the motor in a furnace with a nominal airflow capacity of $1200 \mathrm{cfm}$. Based on this, the Department assumed the new motor would operate at constant efficiency. The shaft power of the BC/ECM+ blower in generic model furnaces divided by this efficiency gives the blower motor electrical power consumption.

The following sections in this appendix provide the details of these calculations and assumptions. 


\section{H.2 SHAFT POWER AND STATIC PRESSURE AT CONSTANT SPEED}

The GE topical report on the development of the prototype blower and motor includes a plot of efficiencies and pressures versus airflow at a constant speed. ${ }^{1}$ The Department measured the values from one and a half dozen points on the curves on this plot. The Department converted the values of these points to units of cfm for airflow and in.w.g. for pressure using a guide for SI units from ASTM. ${ }^{2}$ See Figure H.2.1, Pressure and Shaft Power versus Airflow at Constant Speed.

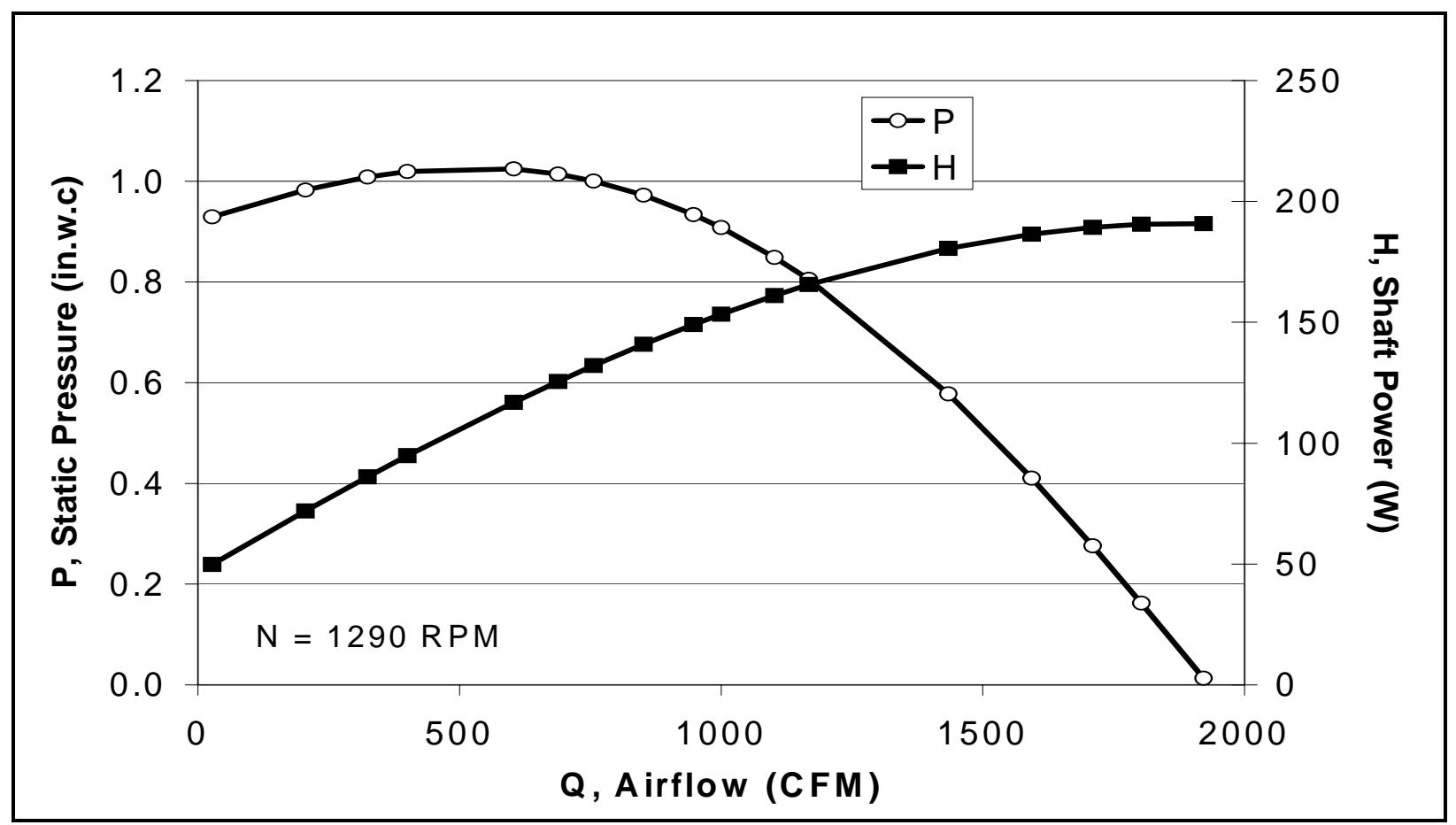

Figure H.1 Pressure and Shaft Power versus Airflow at Constant Speed

The Departrment fit these points to equations for shaft power and static pressure at constant blower speed as polynomial functions of airflow. The equations are:

$$
\begin{gathered}
P(Q)=C 0+C 1 \times\left(\frac{Q}{1000}\right)+C 2 \times\left(\frac{Q}{1000}\right)^{2}+C 3 \times\left(\frac{Q}{1000}\right)^{3}+C 4 \times\left(\frac{Q}{1000}\right)^{4} \\
H(Q)=C 0+C 1 \times\left(\frac{Q}{1000}\right)+C 2 \times\left(\frac{Q}{1000}\right)^{2}+C 3 \times\left(\frac{Q}{1000}\right)^{3}
\end{gathered}
$$

where

$$
\begin{array}{lll}
P & = & \text { static pressure rise across blower (in.w.g.) } \\
H & = & \text { blower shaft power (W) }
\end{array}
$$




$$
\begin{array}{ll}
Q & =\text { airflow }(\mathrm{cfm}) \\
C_{0}, C_{1}, C_{2}, C_{3}, C_{4} & =\text { empirical coefficients from curve fitting }
\end{array}
$$

The coefficients for these equations are shown in Table H.2.1, Coefficients for Shaft Power and Static Pressure at Constant Speed.

Table H.2.1 Coefficients for Shaft Power and Static Pressure at Constant Speed

\begin{tabular}{|lcc|}
\hline & static pressure (P) & shaft power $(\mathbf{H})$ \\
\hline C0 & 0.91982 & 46.32071 \\
C1 & 0.34136 & 127.57380 \\
C2 & -0.11357 & -13.27624 \\
C3 & -0.32487 & -7.27523 \\
C4 & 0.08524 & \\
\hline
\end{tabular}

\section{H.3 BLOWER AT OTHER SPEEDS AND AIRFLOWS}

These equations, combined with the fan laws, allowed the Department to determine shaft power and static pressure for any speed and airflow for this prototype blower. To do this requires finding the equivalent airflow at the test speed, and then scaling the pressure to new speed. ${ }^{3}$ The equations for this are:

$$
\begin{gathered}
\text { Qequiv }=Q \times \frac{\text { Ntest }}{N} \\
P(N, Q)=\text { Ptest }(\text { Qequiv }) \times\left(\frac{N}{N \text { test }}\right)^{2} \\
H(N, Q)=\text { Htest }(\text { Qequiv }) \times\left(\frac{N}{N \text { test }}\right)^{3}
\end{gathered}
$$

where

$$
\begin{array}{ll}
N & =\text { blower speed (rpm) } \\
\text { Ntest } & =\text { blower speed during test (rpm) } \\
Q & =\text { airflow }(\mathrm{cfm}) \\
\text { Qequiv } & =\text { equivalent airflow at test speed (cfm) } \\
P & =\text { static pressure rise across blower (in.w.g.) } \\
\text { Ptest } & =\text { static pressure rise across blower at test speed (in.w.g.) } \\
H & =\text { shaft power of blower }(\mathrm{W}) \\
\text { Htest } & =\text { shaft power of blower at test speed(W) }
\end{array}
$$




\section{H.4 OTHER SIZE BLOWERS}

The prototype blower developed by GE was thought to be designed for only one size furnace, with a nominal airflow of $1200 \mathrm{cfm}$. Wider blowers provide more airflow and require more shaft power to develop the same static pressure. The Department examined the airflow for FOUR forward-curved blowers of the same diameter with different widths (Lau Industries blowers DD10-7A, DD10-8A, DD10-9A, and DD10-10A) when operating at $1075 \mathrm{rpm}$, the nominal speed for PSC motors they are usually driven with. ${ }^{4}$ The ratio of average airflows for these blowers across a representative range of pressures, roughly scaled as the ratio of widths raised to a power of 0.795 . The Department assumed that the shaft power and airflow wider backward-inclined blowers would scale with width at this same rate. The assumed width ratios and resulting scalars for airflow and shaft power for the backward-inclined blowers for the four airflow capacities of the generic model furnaces are shown in Table H.4.1.

Table H.4.1 Scalars for Airflow and Shaft Power for the Backward-Inclined Blowers

\begin{tabular}{|l|c|c|c|c|}
\hline nominal airflow $(\mathrm{cfm})$ & $\mathbf{8 0 0}$ & $\mathbf{1 2 0 0}$ & $\mathbf{1 6 0 0}$ & $\mathbf{2 0 0 0}$ \\
\hline $\begin{array}{l}\text { generic model forward-curved blower } \\
\text { size }\end{array}$ & $9 \times 8$ & $10 \times 8$ & $10 X 10$ & 11 X10 \\
\hline width ratio & 0.875 & 1 & 1.25 & 1.5 \\
\hline scalar & 0.89932 & 1 & 1.19402 & 1.38018 \\
\hline
\end{tabular}

Using these assumptions, finding the pressure for a given airflow for a different width blower means finding the equivalent airflow to calculate the pressure for the prototype blower at the test speed. This is a modification of the techniques used in section H.3, Blower at Other Speeds and Airflows. The equations to find the equivalent airflow and scaled shaft power are:

$$
\begin{gathered}
\text { Qequiv }=Q_{W} \times \frac{N \text { test }}{N} \times \frac{1}{W} \\
H_{w}(N, Q)=\operatorname{Htest}(\text { Qequiv }) \times\left(\frac{N}{N t e s t}\right)^{3} \times \frac{1}{W}
\end{gathered}
$$

where

$$
\begin{array}{ll}
N & =\text { blower speed (rpm) } \\
\text { Ntest } & =\text { blower speed during test }(\mathrm{rpm}) \\
Q_{w} & =\text { airflow of wider blower }(\mathrm{cfm}) \\
\text { Qequiv } & =\text { equivalent airflow at test speed }(\mathrm{cfm})
\end{array}
$$




$$
\begin{array}{ll}
H_{W} & =\text { shaft power of wider blower }(\mathrm{W}) \\
\text { Htest } & =\text { shaft power of blower at test speed(W) }
\end{array}
$$

The equation to calculate pressure is the then same as in section H.3 with the new Qequiv.

\section{H.5 SYSTEM EFFECT FACTOR OF BLOWERS IN FURNACES}

The SEF is the reduction in pressure from the blower operating by itself compared to when the blower is operating in a furnace. The SEF accounts for the effect of obstructions to the airflow and the inlet and outlet geometry of the blower enclosure of the furnace. The Department made the assumption that the fractional change SEF for every $400 \mathrm{cfm}$ change of nominal airflow in the generic model furnaces would also apply for the BC-ECM+ blowers in the generic model furnaces.

The Department fit the SEF of the generic model furnaces to an exponential function of nominal airflow. Figure H.5.1, SEF Versus Nominal Airflow for Generic Model Furnaces, shows values and the fit equation for forward-curved blowers and PSC motors. The equation for SEF as a function of nominal airflow is:

where

$$
S E F=b \times m^{\text {Qnom }}
$$

$$
\begin{array}{ll}
\text { SEF } & =\text { system effect factor } \\
b & =1.227249 \times 10^{6} \\
m & =0.999039 \\
\text { Qnom } & =\text { nominal airflow of blower(cfm) }
\end{array}
$$




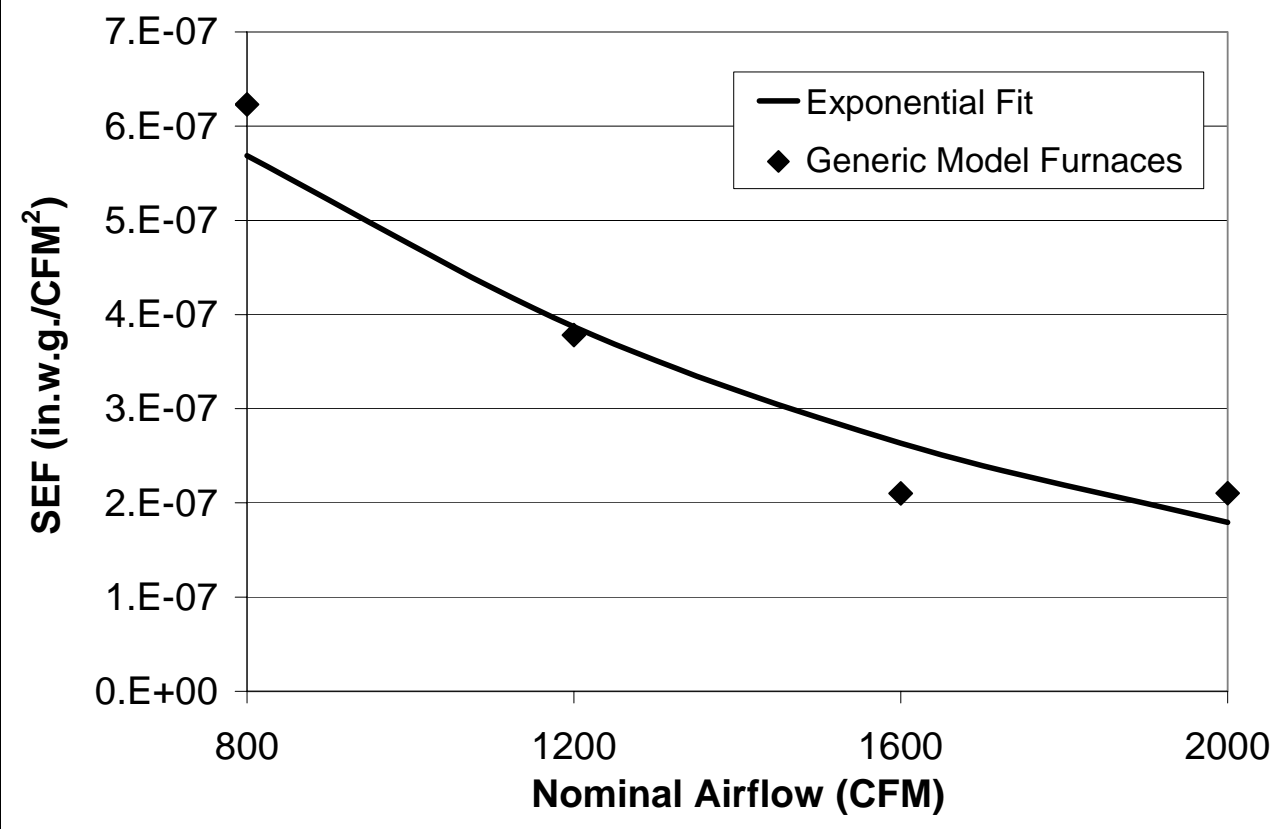

Figure H.1 SEF Versus Nominal Airflow for Generic Model Furnaces

The SEF was calculated independently for the BC-ECM+ at a nominal airflow of 1200 cfm. The equation is:

$$
S E F=\frac{(\text { Pblower }- \text { Pfurn })}{Q^{2}}
$$

where

$$
\begin{aligned}
\text { SEF }= & \text { system effect factor } \\
\text { Pblower }= & \text { static pressure of blower, } 0.781 \text { (in.w.g.), calculated at } 1290 \\
& \text { rpm and } 1200 \mathrm{cfm} \\
\text { Pfurn }= & \text { static pressure of furnace, } 0.5 \text { (in.w.g.) } \\
\text { Qnom }= & \text { nominal airflow of blower, } 1200(\mathrm{cfm})
\end{aligned}
$$

To get the SEF for the other generic model furnaces with BC/ECM+ blowers, DOE calculated the ratio of SEF for the other nominal airflow furnaces to the SEF for this furnace. This was done using the exponential function of SEF versus nominal airflow of the generic model furnaces. The resulting ratios are shown in Table H.5.1, SEF for BC/ECM+ Blowers in Generic Model Furnaces. 
Table H.5.1 SEF for BC/ECM+ Blowers in Generic Model Furnaces

\begin{tabular}{|l|c|c|c|c|}
\hline Nominal Airflow (CFM) & $\mathbf{8 0 0}$ & $\mathbf{1 2 0 0}$ & $\mathbf{1 6 0 0}$ & $\mathbf{2 0 0 0}$ \\
\hline SEF ratio & 1.468938 & 1 & 0.680764 & 0.463439 \\
\hline SEF (in.w.g./CFM ${ }^{2}$ ) & $2.86931 \mathrm{E}-07$ & $1.953 \mathrm{E}-07$ & $1.32975 \mathrm{E}-07$ & $9.05245 \mathrm{E}-08$ \\
\hline
\end{tabular}

\section{H.6 BLOWER SPEED AND SHAFT POWER AS FUNCTION OF FURNACE STATIC PRESSURE}

This section explains how the Department determined blower speed and shaft power for generic model furnaces with $\mathrm{BC} / \mathrm{ECM}+$ blowers from the furnace static pressures.

For furnaces with ECM motors and backward-inclined impellors in the blower, the Department determined the airflow and static pressure at the operating conditions from the intersection of the fan curve of the furnace and the system curve of the ducts. This is done the same way as for standard PSC motors. However, furnaces with these motors are programmed to provide a constant airflow regardless of static pressure. Thus, the fan curves for these furnaces are a vertical line of constant airflow.

The Department evaluated the furnace static pressure at the nominal air flow for each of the generic model furnaces with $\mathrm{BC} / \mathrm{ECM}+$ blowers for a range of blower speeds.

$$
P_{\text {furn }}=P_{\text {blower }}(Q, N)-S E F \times Q^{2}
$$

where

$$
\begin{array}{ll}
P_{\text {furn }} & =\text { furnace static pressure (in.w.g.) } \\
P_{\text {blower }} & =\text { static pressure across blower alone (in.w.g.) } \\
Q & =\text { airflow (cfm) } \\
N & =\text { motor speed (rpm) } \\
\text { SEF } & \text { system effect factor as explained in section H.5 System Effect } \\
& \text { Factor of Blowers in Furnaces }
\end{array}
$$

From these static pressures, the Department developed an equation for blower speed as a function of static pressure at the nominal airflows of the generic model furnaces.

$$
N(\text { Pfurn })=C_{0}+C_{1} \times \text { Pfurn }+C_{2} \times \text { Pfurn }^{2}
$$

where

$$
N \quad=\text { motor speed }(\mathrm{rpm})
$$




$$
\begin{array}{ll}
P_{\text {furn }} & =\text { furnace static pressure (in.w.g.) } \\
C_{0}, C_{1}, C_{2} & =\text { empirical coefficients from curve fitting }
\end{array}
$$

The coefficients for the equations of blower speed as a function of furnace static pressure for generic furnaces with ECM motors and forward-curved impellors is shown in Table H.6.1, Coefficients for Blower Speed Equation.

\begin{tabular}{|c|c|c|c|c|}
\hline & $\mathbf{Q}$ & CO & C1 & $\mathrm{C} 2$ \\
\hline \multicolumn{5}{|l|}{ Cooling } \\
\hline 2 ton & 800 & 771.297930225 & 779.26756805 & -139.008728615 \\
\hline 3 ton & 1200 & 1004.4257405 & 612.718105072 & -82.3858179298 \\
\hline 4 ton & 1600 & 1115.11438648 & 556.374528078 & -66.4367804917 \\
\hline 5 ton & 2000 & 1186.32793032 & 524.106011654 & -58.6030844866 \\
\hline \multicolumn{5}{|l|}{ High Fire } \\
\hline 2 ton & 640.0 & 620.504604012 & 933.280077841 & -205.025304436 \\
\hline 3 ton & 960.0 & 805.339732049 & 744.862082929 & -126.832574748 \\
\hline 4 ton & 1280.0 & 893.475264237 & 679.413794851 & -103.848338196 \\
\hline 5 ton & 1600.0 & 950.264980926 & 641.197789459 & -91.9907933216 \\
\hline \multicolumn{5}{|l|}{ Low Fire } \\
\hline 2 ton & 533.3 & 521.413603686 & 1068.28226839 & -271.834021254 \\
\hline 3 ton & 1200 & 673.447604033 & 866.36860443 & -175.654364949 \\
\hline 4 ton & 1066.7 & 746.403441995 & 793.875638502 & -145.692110892 \\
\hline 5 ton & 1333.3 & 793.449632938 & 751.002693796 & -129.8241 \\
\hline
\end{tabular}

Table H.6.1 Coefficients for Blower Speed Equation

For the same air flow and speeds that were used to evaluate furnace static pressure, DOE evaluated the the blower shaft power using the equations explained earlier in this appendix. From these results, the Department developed an equation for blower shaft power as a function of static pressure at the nominal airflows of the generic model furnaces.

$$
H\left(P f_{u r n}\right)=C_{0}+C_{1} \times P f_{u r n}+C_{2} \times P f_{u r n}^{2}+C_{3} \times P f_{u r n}{ }^{3}
$$

where

$$
\begin{array}{ll}
H & =\text { blower shaft power (which is also the motor output power) }(\mathrm{W}) \\
P_{\text {furn }} & =\text { furnace static pressure (in.w.g.) } \\
C_{0}, C_{1}, C_{2}, C_{3} & =\text { empirical coefficients from curve fitting }
\end{array}
$$

The coefficients for the equations of blower shaft power as a function of furnace static pressure for generic furnaces with ECM motors and forward-curved impellors is shown in Table H.6.2, Coefficients for Blower Shaft Power Equation. 
Table H.6.2 Coefficients for Blower Shaft Power Equation

\begin{tabular}{|c|c|c|c|c|c|}
\hline & $\mathbf{Q}$ & CO & C1 & $\mathrm{C} 2$ & C3 \\
\hline \multicolumn{6}{|c|}{ Cooling } \\
\hline 2 ton & 800 & 34.7637865629 & 101.257496416 & 30.819237206 & -4.393198813 \\
\hline 3 ton & 1200 & 86.8964114725 & 149.648658529 & 24.686091998 & -1.351144007 \\
\hline 4 ton & 1600 & 142.379224744 & 199.258007379 & 25.830716411 & -0.75624128 \\
\hline 5 ton & 2000 & 199.168681228 & 247.410917528 & 26.886578305 & -0.163068387 \\
\hline \multicolumn{6}{|c|}{ High Fire } \\
\hline 2 ton & 640 & 17.7814395418 & 81.4599546929 & 36.760753941 & -6.820695201 \\
\hline 3 ton & 960 & 44.4918524165 & 119.54001273 & 31.765403864 & -3.666136066 \\
\hline 4 ton & 1280 & 72.9202558294 & 159.014401208 & 33.753367048 & -2.927933696 \\
\hline 5 ton & 1600 & 101.991203084 & 197.482373726 & 35.406395106 & -2.130855013 \\
\hline \multicolumn{6}{|c|}{ Low Fire } \\
\hline 2 ton & 533.3 & 10.2554469313 & 68.6525919364 & 41.182715094 & -8.986586445 \\
\hline 3 ton & 800 & 25.7529563782 & 99.6988982718 & 37.766224552 & -6.017676309 \\
\hline 4 ton & 1066.7 & 42.197172414 & 132.467356467 & 40.800818335 & -5.419757563 \\
\hline 5 ton & 1333.3 & 59.0319912122 & 164.29823146 & 43.598086888 & -4.793958254 \\
\hline
\end{tabular}

\section{H.7 ECM 4.0 MOTOR EFFICIENCY}

The GE topical report listed the efficiency of the prototype ECM 4.0 motor at two operating conditions. ${ }^{1}$ The two points, which roughly span the intended operating range of the prototype motor, are at the target operating condition and at the maximum operating conditions. The motor efficiencies at these two operating conditions were $86.0 \%$ and $84.7 \%$, respectively. Figure H.7.1, Efficiencies and Operating Range of Prototype Motor, shows these data points against the targeted operating range of the motor. Based on this, the Department assumed the new motor would operate at constant efficiency of $85 \%$. 


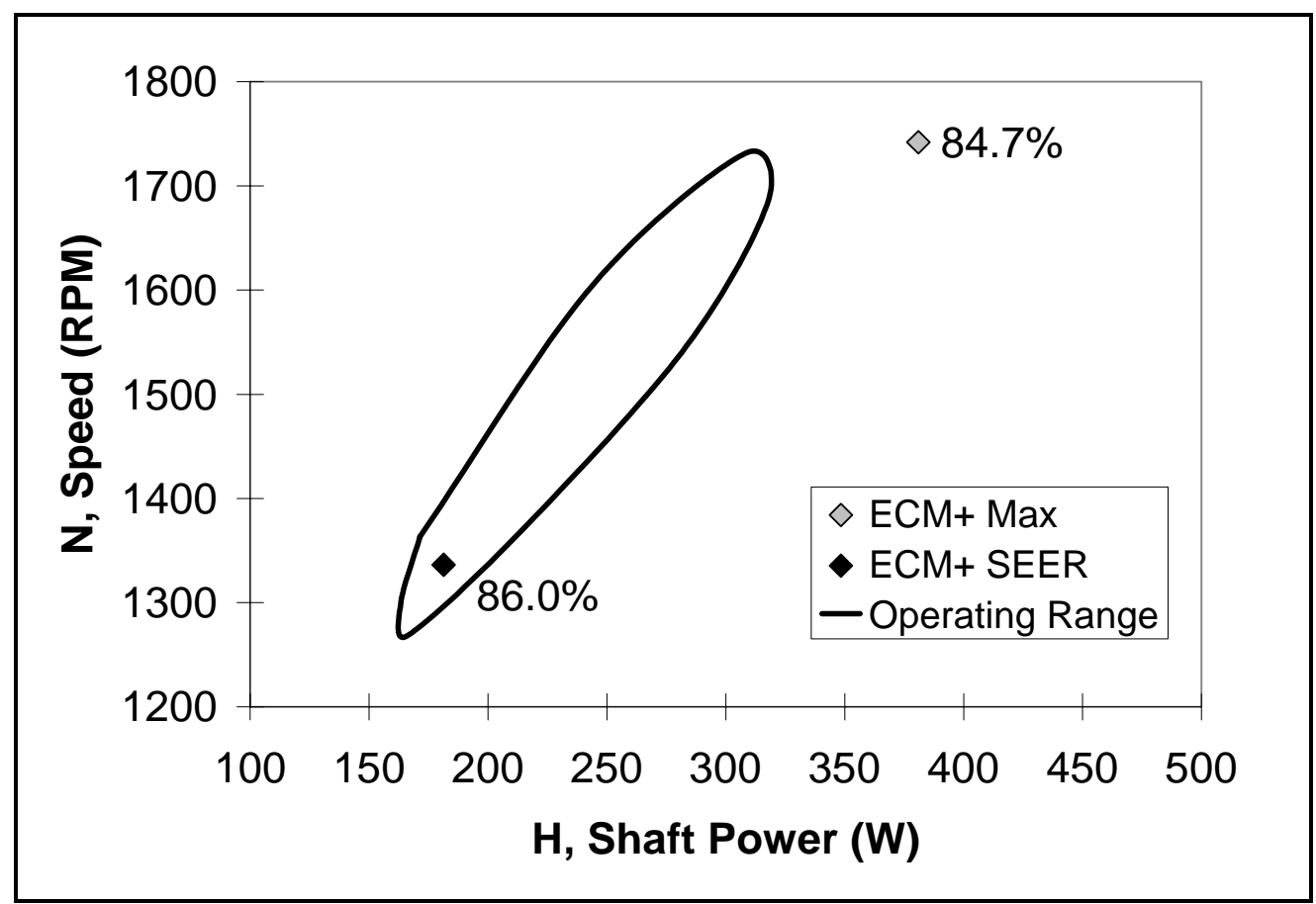

Figure H.1 Efficiencies and Operating Range of Prototype Motor

\section{H.8 BC/ECM+ BLOWER MOTOR ELECTRICITY CONSUMPTION}

The shaft power of the BC/ECM+ blower in generic model furnaces divided by efficiency gives the blower motor electrical power consumption.

$$
B E=\frac{H w(N, Q)}{\eta_{\text {motor }}}
$$

where

$$
\begin{array}{ll}
N & =\text { blower speed at operating static pressure of furnace (rpm) } \\
Q_{W} & =\text { airflow of wider blower at operating static pressure of furnace } \\
& (\mathrm{cfm}) \\
H_{W} & = \\
\eta_{\text {motor }} & \text { shaft power of wider blower (W) }
\end{array}
$$




\section{REFERENCES}

1. Wang, S. and H. Wiegman, Topical Progress Report for the Variable Speed Integrated Intelligent HVAC Blower, November 14, 2001, GE Corporate Research and Development. Niskayuna, NY.

2. American Society for Testing and Materials, Standard Practice for Use of the International System of Units (SI) (the Modernized Metric System), 1992. Philadelphia, PA. PCN 03-543-092-34. Report No. E 380-92.

3. Air Movement and Control Association International Inc., Fans and Systems, in AMCA Publication 201-90. 1990: Arlington Heights, IL.

4. $\quad$ Lau Industries, Whirl Wind IV, Version 4.0, Fan Application Software. 2000.

http://www.lau-ind.com/whirlwind.htm 


\section{APPENDIX I: ELECTRICITY AND GAS USE FOR MODULATING FURNACES}

\section{TABLE OF CONTENTS}

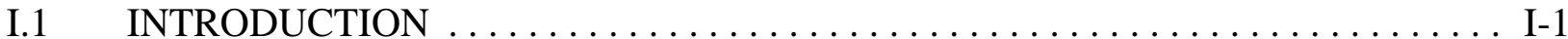

I.2 BURNER OPERATING HOURS $\ldots \ldots \ldots \ldots \ldots \ldots \ldots \ldots \ldots \ldots \ldots$ I-1

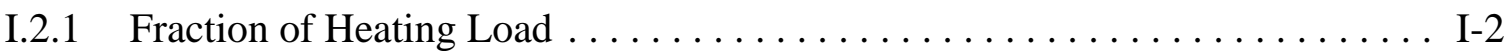

I.2.2 Balance-Point Temperature $\left(\mathrm{T}_{\mathrm{C}}\right) \ldots \ldots \ldots \ldots \ldots \ldots \ldots \ldots \ldots \ldots \ldots \ldots \ldots \ldots \ldots \ldots \ldots \ldots$

I.2.3 Oversize Factor $(\alpha) \ldots \ldots \ldots \ldots \ldots \ldots \ldots \ldots \ldots \ldots \ldots \ldots \ldots \ldots \ldots \ldots \ldots \ldots \ldots$

I.2.4 Heating Capacity at Maximum Input Rate $\left(\mathrm{Q}_{\text {out }}\right) \ldots \ldots \ldots \ldots \ldots \ldots \ldots \ldots \ldots$

I.2.5 Reduced Fuel Input Rate Heating Capacity $\ldots \ldots \ldots \ldots \ldots \ldots \ldots \ldots$ I-4

I.2.6 Design Heating Requirement (DHR) $\ldots \ldots \ldots \ldots \ldots \ldots \ldots \ldots \ldots \ldots \ldots \ldots \ldots \ldots \ldots$

I.2.7 Annual Average Heating Energy $\left(\mathrm{E}_{\mathrm{M}}\right) \ldots \ldots \ldots \ldots \ldots \ldots \ldots \ldots \ldots \ldots \ldots \ldots \ldots \ldots$

I.3 FAN MOTOR ELECTRICITY CONSUMPTION $(\mathrm{BE}) \ldots \ldots \ldots \ldots \ldots \ldots \ldots$ I-6

\section{LIST OF TABLES}

Table I.2.1 $\mathrm{Q}_{\text {out }}$ and Corresponding DHR values $\ldots \ldots \ldots \ldots \ldots \ldots \ldots \ldots \ldots \ldots \ldots$

Table I.3.1 ECM+ Fan Curves . . . . . . . . . . . . . . . . . . . . . . . . . . . . . . I-7

Table I.3.2 BC/ECM+ Fan Curves ( $\mathrm{H}$ is in $\mathrm{W}$ for these equations) $\ldots \ldots \ldots \ldots \ldots$ I-8

\section{LIST OF FIGURES}

Figure I.1 $\quad \mathrm{X}_{\mathrm{R}}$ and $\mathrm{X}_{\mathrm{H}}$ versus Balance-point Temperature for Modulating Furnaces and Boilers 


\section{APPENDIX I: ELECTRICITY AND GAS USE FOR MODULATING FURNACES}

\section{I.1 INTRODUCTION}

We modeled two-stage modulating furnaces with high and reduced firing rates. The two different firing rates change the amount of electricity and gas consumed by the circulating air blower motor and the furnace burner. This appendix describes how DOE calculated the gas consumed by the burner and electricity consumed by the circulating air blower motor at the two firing rates. This calculation method is based on the procedure in the ASHRAE Standard 103 test procedure. $^{1}$

The gas consumed by the burner during the two firing rates depends on the amount of time the burner is firing at each mode and the gas consumption rates. The first section of this appendix discusses the calculation for burner operating hours and firing rates. The six variables for the burner operating hours calculation are: fraction of heating load, balance-point temperature, oversize factor, heating capacity at high rate, heating capacity at reduced rate, and the design heating requirement. The second section describes the circulating blower motor electricity consumption calculation.

\section{I.2 BURNER OPERATING HOURS}

We calculated burner operating hours as shown below for reduced firing (R) and high firing $(\mathrm{H})$.

$$
B O H_{R}=\frac{X_{R} \cdot E_{M}}{Q_{I N, R}}
$$

where;

$X_{R} \quad=$ fraction of heating load at reduced fuel input rate operating mode,

$E_{M} \quad=$ average annual energy used during the heating season (kBtu), and

$Q_{I N, R}=$ steady-state reduced fuel input rate $(\mathrm{kBtu} / \mathrm{h})$.

$$
B O H_{H}=\frac{X_{H} \cdot E_{M}}{Q_{I N}}
$$

where;

$X_{H}=$ fraction of heating load at high, or maximum, fuel input rate operating mode,

$E_{M}=$ average annual energy used during the heating season (kBtu), and

$Q_{I N}=\quad$ steady-state high, or maximum, fuel input rate $(\mathrm{kBtu} / \mathrm{h})$. 


\section{I.2.1 Fraction of Heating Load}

DOE determined $\mathrm{X}_{\mathrm{H}}$ and $\mathrm{X}_{\mathrm{R}}$, the fraction of heating load at the maximum and reduced fuel input operating modes, from a correlation with the balance-point temperature according to the ASHRAE test procedure ${ }^{1}$

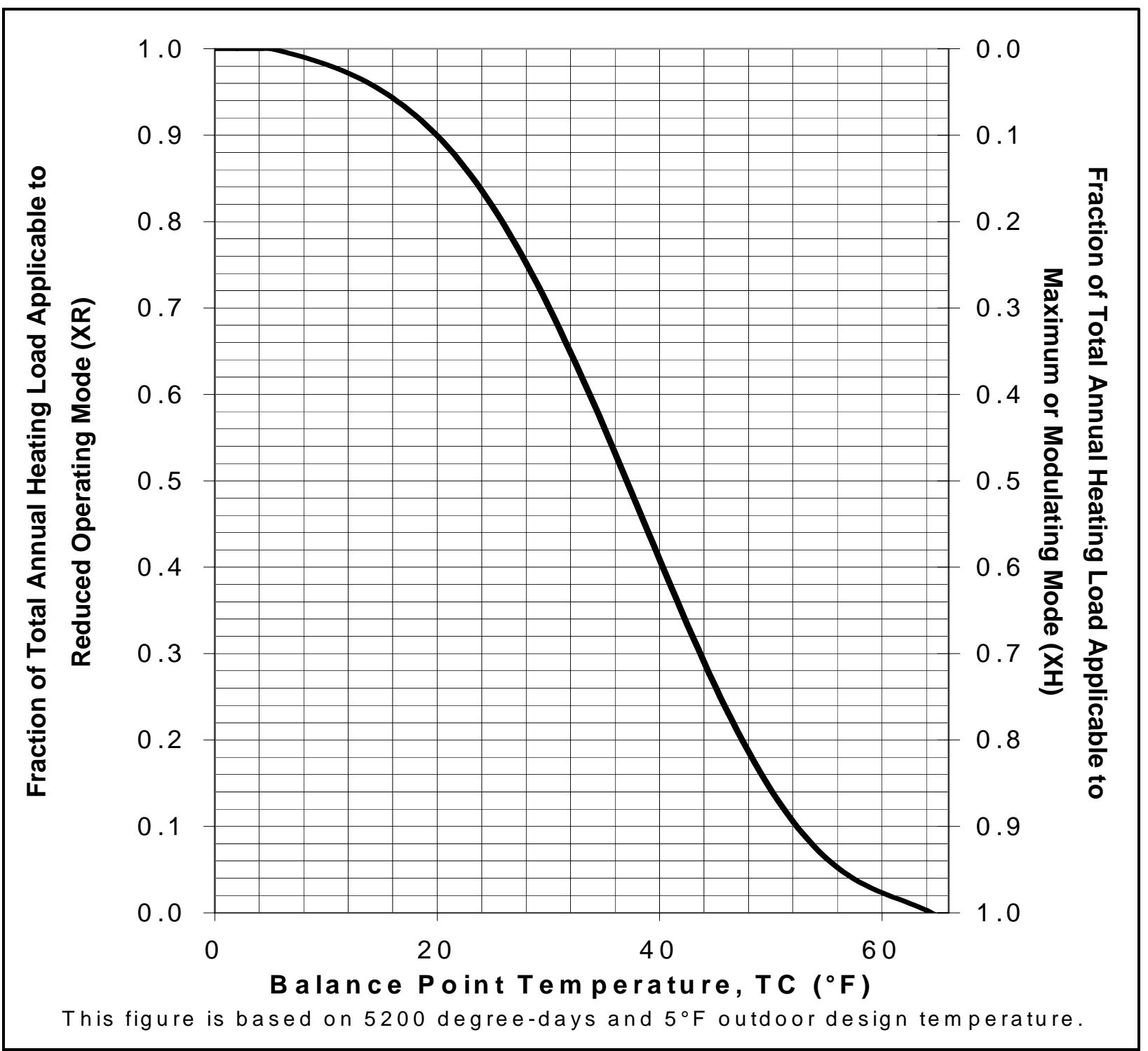

Figure I.1 $X_{R}$ and $X_{H}$ versus Balance-point Temperature for Modulating Furnaces and Boilers 


\section{I.2.2 Balance-Point Temperature $\left(\mathrm{T}_{\mathrm{C}}\right)$}

The balance-point temperature apportions the annual heating load between the reduced cycling mode and maximum-cycle mode. We calculated the balance-point temperature as

$$
T_{C}=65-\left[(60) \times(1-\alpha) \times \frac{Q_{\text {OUT }} R}{\text { QouT }}\right]
$$

Where;

$\begin{array}{lll}65 & & \begin{array}{l}\text { typical average outdoor temperature at which a furnace or boiler } \\ \text { starts operating }\left({ }^{\circ} \mathrm{F}\right),\end{array} \\ 60 & & \begin{array}{l}\text { the difference between } 65^{\circ} \mathrm{F} \text { and the typical outdoor design } \\ \text { temperature of } 5^{\circ} \mathrm{F}\left({ }^{\circ} \mathrm{F}\right),\end{array} \\ \alpha & = & \text { oversize factor. } \\ \text { QouT, } \mathrm{R} & = & \text { heating capacity at reduced fuel input rate }(\mathrm{kBtu} / \mathrm{h}), \text { and } \\ \text { Qout } & = & \text { heating capacity at maximum fuel input rate }(\mathrm{kBtu} / \mathrm{h}) .\end{array}$

If the balance point temperature is less than zero, we used $\mathrm{T}_{\mathrm{C}}=0$.

\section{I.2.3 Oversize Factor $(\alpha)$}

The oversize factor, $\alpha$, is a ratio between the heating capacity at the maximum fuel input rate and the design heating requirement (DHR), less 1.

$$
\alpha=\frac{\text { QOUT }}{D H R}-1
$$

where,

Qоuт $=$ heating capacity at maximum fuel input rate $(\mathrm{kBtu} / \mathrm{h})$,

$D H R=$ design heating requirement as defined in ASHRAE Standard 103.

We derived these equations by fitting a linear function of input capacity and AFUE to the heating capacity of the furnace models listed in the GAMA directory.

\section{I.2.4 Heating Capacity at Maximum Input Rate $\left(\mathbf{Q}_{\text {out }}\right)$}

The $\mathrm{Q}_{\text {out }}$ is expressed to the nearest $1000 \mathrm{Btu} / \mathrm{h}$ and is calculated for non-condensing and condensing furnaces as;

$$
\text { Q }
$$




$$
\text { QouT }=\text { QIN } \times(0.7247 \times \text { AFUE }+22.346) \text { for condensing. }
$$

\section{I.2.5 Reduced Fuel Input Rate Heating Capacity}

For $Q_{\text {OUT,R }}$, we assumed that the steady state efficiency at the reduced input rate is the same as a maximum input rate. Thus, the reduced fuel input heating capacity is:

$$
Q_{O U T, R}=Q_{I N, R} \times \frac{Q_{O U T}}{Q_{I N}}
$$

\section{I.2.6 Design Heating Requirement (DHR)}

Table I.2.1 shows Design Heating Requirements (DHR) for boilers and furnaces with different output capacities, from the ASHRAE test procedure. 
Table I.2.1 $\mathrm{Q}_{\text {OUT }}$ and Corresponding DHR values

\begin{tabular}{|c|c|}
\hline Output Capacity (Btu/h) & DHR (kBtu/h) \\
\hline $5000-10,000$ & 5 \\
\hline $11,000-16,000$ & 10 \\
\hline $17,000-25,000$ & 15 \\
\hline $26,000-42,000$ & 20 \\
\hline $43,000-59,000$ & 30 \\
\hline $60,000-76,000$ & 40 \\
\hline $77,000-93,000$ & 50 \\
\hline $94,000-110,000$ & 60 \\
\hline $111,000-127,000$ & 70 \\
\hline $127,000-144,000$ & 80 \\
\hline $145,000-161,000$ & 90 \\
\hline $162,000-178,000$ & 100 \\
\hline $179,000-195,000$ & 110 \\
\hline 196,000 and over & 130 \\
\hline
\end{tabular}

\section{I.2.7 Annual Average Heating Energy $\left(E_{M}\right)$}

For furnaces and boilers equipped with two-stage or step modulating controls, the average annual energy used during the heating season, $\mathrm{E}_{\mathrm{M}}$, from ANSI/ASHRAE Standard 103-1993 is defined as:

$$
E_{M}=\left(Q_{I N}-Q_{P}\right) \times B O H s S+(8760-4600) \times Q_{P}
$$

where;

$Q_{I N}=$ steady-state nameplate maximum fuel input rate,

$\mathrm{BOH}_{s s}=$ national average number of burner operating hours

$Q_{P} \quad=\quad$ fuel input from pilot light(for non-weatherized gas furnaces, there is no pilot light so $\mathrm{Q}_{\mathrm{P}}=0$ ),

$$
E_{M}=Q_{I N} \times B O H s S
$$


For induced draft units,

$$
\begin{aligned}
& A=\frac{100000}{341300 \times\left(y_{I G} \times P E_{I G}+y \times B E\right) \times R+\left(Q_{I N}-Q_{P}\right) \times E f f y H S} \\
& B O H s S=H H L \times \frac{1000000}{\left[Q_{I N} \times A F U E \times 1000+3.413 \times\left(1-\eta_{\text {overall }} \times B E \times y \times P E_{I G} \times y_{I G}\right) \times R\right]} \\
& \mathrm{HHL}=\text { the annual household heating load }(\mathrm{kBtu} / \mathrm{yr}) \text {, } \\
& \eta_{\text {coverall }}=\quad \text { overall efficiency of the blower and blower motor, } \\
& \mathrm{PE}_{\mathrm{IG}}=\text { electrical input rate to the interrupted ignition device on burner, and } \\
& \mathrm{y}_{\mathrm{IG}}=\quad \text { ratio of ignition device on-time to average burner ontime, as defined in } \\
& \text { 10.2.1 of DOE test procedure. } \\
& \mathrm{R}=3.0, \quad \text { for step modulating controls when the ratio of minimum-to-maximum } \\
& \text { output is less than } 0.5 \text {. (For non-weatherized gas furnaces, the ratio of } \\
& \text { minimum-to-maximum output is } 40 \% \text { for step modulating, indicating } \mathrm{R}= \\
& \text { 3.0.) }
\end{aligned}
$$

This equation for $\mathrm{BOH}_{\mathrm{SS}}$ is similar to the equation from the test procedure ${ }^{2}$. The main difference is that the LCC spreadsheet has a House Heating Load for each house, while the test procedure equation uses average Heating Load Hours and DHR. This gives $\mathrm{E}_{\mathrm{M}}$ as

\section{I.3 FAN MOTOR ELECTRICITY CONSUMPTION (BE)}

In step-modulating furnaces, the circulating blower motor operates at two different rates. The high firing rate is equal to the non-modulating furnace fan blower motor speed. The burner and the fan motor are coordinated so that when the burner is operating at a particular rate, the fan motor matches the level.

Tables I.3.1-I.3.2 show equations and coefficients for high, reduced, and cool modes of electricity use for two different fan motor types: ECM and BC/ECM. 
Table I.3.1 ECM+ Fan Curves

\begin{tabular}{|c|c|c|c|c|c|c|c|c|c|c|c|c|}
\hline \multicolumn{2}{|c|}{ H fit Heat (high) } & \multicolumn{3}{|c|}{$\mathbf{H}=\mathbf{C}_{0}+\mathbf{C}_{1} * \mathbf{p}+\mathbf{C}_{2} * \mathbf{p}^{2}+\mathbf{C}_{3} * \mathbf{p}^{3}$} & \multicolumn{4}{|c|}{ H fit Heat (low) } & \multicolumn{4}{|c|}{ H fit Cool } \\
\hline & $\mathrm{C}_{0}$ & $\mathrm{C}_{1}$ & $\mathbf{C}_{2}$ & $\mathrm{C}_{3}$ & $\mathrm{C}_{0}$ & $\mathrm{C}_{1}$ & $\mathrm{C}_{2}$ & $\mathrm{C}_{3}$ & $\mathrm{C}_{0}$ & $\mathrm{C}_{1}$ & $\mathrm{C}_{2}$ & $\mathrm{C}_{3}$ \\
\hline 2 ton & 0.008 & 0.042 & 0.028 & -0.007 & 0.005 & 0.036 & 0.029 & -0.007 & 0.0153 & 0.0507 & 0.0257 & -0.0056 \\
\hline 3ton & 0.108 & 0.192 & 0.014 & 0.007 & 0.062 & 0.158 & 0.023 & 0.006 & 0.2105 & 0.2417 & 0.0079 & 0.0054 \\
\hline 4ton & 0.166 & 0.270 & 0.042 & -0.002 & 0.096 & 0.225 & 0.051 & -0.004 & 0.3234 & 0.3375 & 0.0327 & -0.0004 \\
\hline 5ton & 0.269 & 0.346 & 0.054 & -0.028 & 0.156 & 0.291 & 0.052 & -0.034 & 0.5250 & 0.4308 & 0.0462 & -0.0159 \\
\hline \multicolumn{2}{|c|}{ N fit Heat (high) } & \multicolumn{3}{|c|}{$\mathbf{N}=\mathbf{C}_{0}+\mathbf{C}_{1}{ }^{*} \mathbf{p}+\mathbf{C}_{2}^{*} \mathbf{p}^{2}+\mathbf{C}_{3}{ }^{*} \mathbf{p}^{3}$} & \multicolumn{4}{|c|}{ N fit Heat (low) } & \multicolumn{4}{|c|}{ N fit Cool } \\
\hline & $\mathrm{C}_{0}$ & $\mathrm{C}_{1}$ & $\mathrm{C}_{2}$ & $\mathrm{C}_{3}$ & $\mathrm{C}_{0}$ & $\mathrm{C}_{1}$ & $\mathrm{C}_{2}$ & $\mathrm{C}_{3}$ & $\mathrm{C}_{0}$ & $\mathrm{C}_{1}$ & $\mathrm{C}_{2}$ & $\mathrm{C}_{3}$ \\
\hline 2ton & 608.29 & 994.40 & -510.65 & 173.21 & 506.04 & 1164.80 & -727.03 & 265.41 & 758.51 & 818.31 & -314.27 & 88.07 \\
\hline 3ton & 600.52 & 658.80 & -172.32 & 59.05 & 505.36 & 716.90 & -95.81 & 0.00 & 749.38 & 539.73 & -113.77 & 32.91 \\
\hline 4ton & 598.34 & 567.41 & -77.76 & 0.00 & 500.32 & 662.77 & -106.86 & 0.00 & 746.78 & 462.47 & -48.57 & 0.00 \\
\hline 5ton & 682.74 & 558.79 & -85.34 & 0.00 & 569.15 & 666.98 & -141.53 & 0.00 & 853.50 & 446.47 & -43.06 & 0.00 \\
\hline
\end{tabular}


Table I.3.2 BC/ECM+ Fan Curves ( $\mathrm{H}$ is in $\mathrm{W}$ for these equations)

\begin{tabular}{|c|c|c|c|c|c|c|c|c|c|c|c|c|}
\hline \multicolumn{2}{|c|}{ H fit Heat (high) } & \multicolumn{3}{|c|}{$\mathbf{H}=\mathbf{C}_{0}+\mathbf{C}_{1}{ }^{*} \mathbf{p}+\mathbf{C}_{2}{ }^{*} \mathbf{p}^{2}+\mathbf{C}_{3}{ }^{*} \mathbf{p}^{3}$} & \multicolumn{4}{|c|}{ H fit Heat (low) } & \multicolumn{4}{|c|}{ H fit Cool } \\
\hline & $\mathrm{C}_{0}$ & $\mathrm{C}_{1}$ & $\mathbf{C}_{2}$ & $\mathbf{C}_{3}$ & $\mathrm{C}_{0}$ & $\mathrm{C}_{1}$ & $\mathbf{C}_{2}$ & $\mathrm{C}_{3}$ & $\mathrm{C}_{0}$ & $\mathrm{C}_{1}$ & $\mathbf{C}_{2}$ & $\mathbf{C}_{3}$ \\
\hline 2 ton & 17.781 & 81.460 & 36.761 & -6.821 & 10.255 & 68.653 & 41.183 & -8.987 & 34.764 & 101.257 & 30.819 & -4.393 \\
\hline 3ton & 44.492 & 119.540 & 31.765 & -3.666 & 25.753 & 99.699 & 37.766 & -6.018 & 86.896 & 149.649 & 24.686 & -1.351 \\
\hline 4ton & 72.920 & 159.014 & 33.753 & -2.928 & 42.197 & 132.467 & 40.801 & -5.420 & 142.379 & 199.258 & 25.831 & -0.756 \\
\hline 5ton & 101.991 & 197.482 & 35.406 & -2.131 & 59.032 & 164.298 & 43.598 & -4.794 & 199.169 & 247.411 & 26.887 & -0.163 \\
\hline \multicolumn{2}{|c|}{$\mathrm{N}$ fit Heat (high) } & \multicolumn{3}{|c|}{$\mathbf{N}=\mathbf{C}_{0}+\mathbf{C}_{1}{ }^{*} \mathbf{p}+\mathbf{C}_{2}{ }^{*} \mathbf{p}^{2}+\mathbf{C}_{3}{ }^{*} \mathbf{p}^{3}$} & \multicolumn{4}{|c|}{$\mathrm{N}$ fit Heat (low) } & \multicolumn{4}{|c|}{ N fit Cool } \\
\hline & $\mathrm{C}_{0}$ & $\mathrm{C}_{1}$ & $\mathbf{C}_{2}$ & $\mathrm{C}_{3}$ & $\mathbf{C}_{0}$ & $\mathrm{C}_{1}$ & $\mathbf{C}_{2}$ & $\mathrm{C}_{3}$ & $\mathbf{C}_{0}$ & $\mathrm{C}_{1}$ & $\mathbf{C}_{2}$ & $\mathbf{C}_{3}$ \\
\hline 2 ton & 620.50 & 933.28 & -205.03 & 0.00 & 521.41 & 1068.28 & -271.83 & 0.00 & 771.30 & 779.27 & -139.01 & 0.00 \\
\hline 3ton & 805.34 & 744.86 & -126.83 & 0.00 & 673.45 & 866.37 & -175.65 & 0.00 & 1004.43 & 612.72 & -82.39 & 0.00 \\
\hline 4ton & 893.48 & 679.41 & -103.85 & 0.00 & 746.40 & 793.88 & -145.69 & 0.00 & 1115.11 & 556.37 & -66.44 & 0.00 \\
\hline 5ton & 950.26 & 641.20 & -91.99 & 0.00 & 793.45 & 751.00 & -129.82 & 0.00 & 1186.33 & 524.11 & -58.60 & 0.00 \\
\hline
\end{tabular}




\section{REFERENCES}

1. American Society for Heating Refrigeration and Air-Conditioning Engineers, Method of Testing for Annual Fuel Ultilization Efficiency of Residential Central Furnaces and Boilers, 1993, ANSI/ASHRAE. Atlanta, GA. Report No. Standard 103-1993.

2. $\quad$ Title 10, Code of Federal Regulations, Chapter II Part 430 Appendix N, Subpart BUniform Test Method for Measuring the Energy Consumption of Furnaces, January 1, 2001. 


\section{APPENDIX J: AIR CONDITIONER OPERATING HOURS}

\section{TABLE OF CONTENTS}

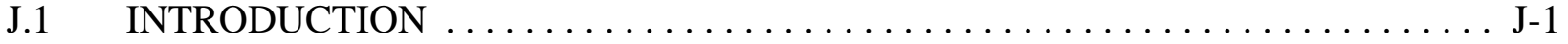

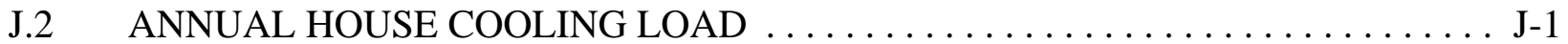

J.3 ANNUAL AIR CONDITIONER OPERATING HOURS $\ldots \ldots \ldots \ldots \ldots \ldots \ldots$ J-1

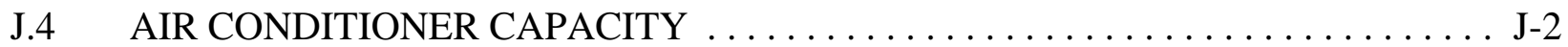

J.5 HEAT ADDED BY BLOWER AND BLOWER MOTOR ................ J-2

J.6 IMPACT OF NEW BLOWER AND/OR BLOWER MOTOR DESIGN OPTIONS .. J-3 


\section{APPENDIX J: AIR CONDITIONER OPERATING HOURS}

\section{J.1 INTRODUCTION}

A more efficient blower and/or blower motor design option means that reduced amounts of waste heat from the blower and/or motor will be added to the cooled air stream generated by the air conditioner. This means the air-conditioner operating hours are reduced. Since the annual house cooling load does not change when a furnace with a more efficient blower and/or blower motor is installed, the cooling provided to the house by the HVAC system remains the same.

This appendix explains how DOE calculated the reduced air conditioner operating hours for a furnace with a more efficient blower and/or blower motor design option. The steps in the calculation include determination for: annual house cooling load, annual air conditioning operating hours, air conditioner capacity, heat amount added by the blower and blower motor, and the impact of new blower and/or blower motor design options.

\section{J.2 ANNUAL HOUSE COOLING LOAD}

We calculated annual house cooling load (HCL) in Btu's as:

$$
H C L=R E C S C O O l \times S E E R
$$

where

HCL = house annual cooling load (Btu/yr)

RECSCOol = house annual cooling energy consumption from RECS97 $(\mathrm{kWh} / \mathrm{yr})^{1}$

SEER = seasonal energy efficiency ratio $(\mathrm{Btu} / \mathrm{h} / \mathrm{kWh})$

\section{J.3 ANNUAL AIR CONDITIONER OPERATING HOURS}

The annual air conditioner operating hours is given by:

$$
A C O H=\frac{H C L}{A C c a p}
$$

where

$$
\begin{aligned}
& \mathrm{ACOH}=\text { annual air conditioner operating hours }(\mathrm{hr} / \mathrm{yr}) \\
& \text { HCL = house annual cooling load (Btu/yr) } \\
& \text { ACcap = cooling capacity of the air conditioner and the furnace blower } \\
& \text { and motor (Btu/h) }
\end{aligned}
$$




\section{J.4 AIR CONDITIONER CAPACITY}

The air conditioner capacity can be thought of as the rate of cooling provided by the evaporator coil minus the rate at which heat is added back to the air stream by inefficiencies of the blower and the blower motor.

$$
\text { ACcap }=\dot{Q}_{\text {evap }}-\dot{Q}_{\text {blower }}
$$

where

$$
\begin{aligned}
\text { ACcap }= & \text { cooling capacity of the air conditioner and the furnace blower } \\
& \text { and motor }(\mathrm{Btu} / \mathrm{h}) \\
= & \text { rate of cooling provided by the evaporator coil }(\mathrm{Btu} / \mathrm{h}) \\
\dot{Q}_{\text {evap }} & \text { rate of heating provided by the inefficiencies of the blower and } \\
& \dot{Q}_{\text {blower }}
\end{aligned}
$$

\section{J.5 HEAT ADDED BY BLOWER AND BLOWER MOTOR} is :

The rate of heat added to the air stream by inefficiencies of the blower and blower motor

$$
\dot{Q}_{\text {blower }}=B E \times(1-\eta) \times 3.412
$$

where

$$
\begin{array}{lll}
\dot{Q}_{\text {blower }}= & \text { rate of heating provided by the inefficiencies of the blower and } \\
& \text { blower motor }(\text { Btu/h) } \\
\mathrm{BE} & \text { blower motor power consumption in cooling mode }(\mathrm{W}) \\
\eta & \text { overall air moving efficiency of blower and blower motor in } \\
& \text { cooling mode } \\
= & \text { conversion factor }(\mathrm{Btu} / \mathrm{h} / \mathrm{W})
\end{array}
$$

\footnotetext{
${ }^{a}$ This does not include the heat added by the motion of the air through the ducts and house. We assumed that the amount of air moved with the new and existing, blower and blower motor design options would be about the same, so this extra heat was not accounted for.
} 


\section{J.6 IMPACT OF NEW BLOWER AND/OR BLOWER MOTOR DESIGN OPTIONS}

Since the house cooling load is not affected by a new blower and/or blower motor design option, the house cooling load will remain the same with existing and new blower and/or blower motor. This is expressed as:

where

$$
\text { HCLexist }=H C L_{\text {new }}
$$

$$
\begin{aligned}
H C L_{\text {exist }}= & \text { house cooling load with the existing furnace blower and blower } \\
& \text { motor (Btu/yr) } \\
H C L_{\text {new }}= & \text { house cooling load with the new furnace blower and/or blower } \\
& \text { motor design options (Btu/yr) }
\end{aligned}
$$

This last equation can be combined with the earlier equations to give:

$$
\text { ACOHexist } \times\left(\dot{Q}_{\text {evap }}-\dot{Q}_{\text {blower }} \text { exist }\right)=\text { ACOHnew } \times\left(\dot{Q}_{\text {evap }}-\dot{Q}_{\text {blowernew }}\right)
$$

which can be rearranged as:

$$
\text { ACOHnew }=\frac{\left(\dot{Q}_{\text {evap }}-\dot{Q}_{\text {blowerexist }}\right)}{\left(\dot{Q}_{\text {evap }}-\dot{Q}_{\text {blowernew }}\right)} \times \text { ACOHexist }
$$

or, with further expansion as:

$$
\text { ACOHnew }=\frac{\left[\frac{H C L}{\text { ACOHexist }}+\text { BEexist } \times\left(1-\eta_{\text {exist }}\right) \times 3.412-\text { BEexist } \times\left(1-\eta_{\text {exist }}\right) \times 3.412\right]}{\left[\frac{H C L}{\text { ACOHexist }}+\text { BEexist } \times\left(1-\eta_{\text {exist }}\right) \times 3.412-\text { BEnew } \times\left(1-\eta_{\text {new }}\right) \times 3.412\right]} \times \text { ACOHexist }
$$

which can then be further simplified as:

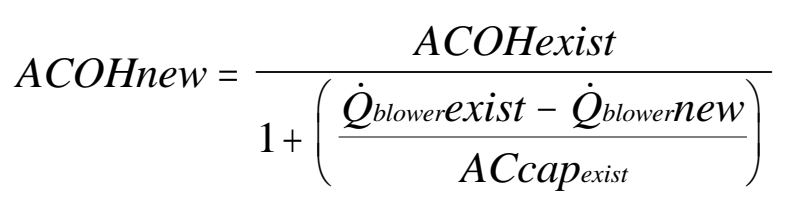




\section{REFERENCE}

1. U.S. Department of Energy - Energy Information Administration, Residential Energy Consumption Survey: Household Energy Consumption and Expenditures 1997, 1999. Washington, DC. Report No. DOE/EIA-0321(97).

$<$ http://www.eia.doe.gov/emeu/recs/recs97/publicusefiles.html> 